FHWA/IN/JTRP-2009/6

Final Report

REVIEW CONSTRUCTION TECHNIQUES FOR ACCELERATED CONSTRUCTION AND COST IMPLICATIONS

Joo Hyoung (Jay) Lee

Bob G. McCullouch

August 2009 
Final Report

FHWA/IN/JTRP-2009/6

\title{
Review Construction Techniques for Accelerated Construction and Cost Implications
}

\author{
By \\ Joo Hyoung (Jay) Lee, Ph.D., P.E. \\ Assistant Professor \\ Department of Construction Management \& \\ Engineering Technologies \\ School of Technology \\ Purdue University Calumet \\ and \\ Bob McCullouch, Ph.D., P.E. \\ Information Technology Administrator/ \\ Research Scientist \\ Joint Transportation Research Program \\ School of Civil Engineering \\ Purdue University \\ Joint Transportation Research Program \\ Project No. C-36-67 WWWW \\ File No. 9-10-100 \\ SPR- 3201 \\ Conducted in Cooperation with the \\ Indiana Department of Transportation \\ and the Federal Highway of Administration \\ U.S. Department of Transportation
}

The contents of this report reflect the views of the authors who are responsible for the facts and the accuracy of the data presented herein. The contents do not necessarily reflect the official views or policies of the Federal Highway Administration and the Indiana Department of Transportation. This report does not constitute a standard, specification or regulation.

Purdue University

West Lafayette, Indiana 47907

August 2009 
TECHNICAL REPORT STANDARD TITLE PAGE

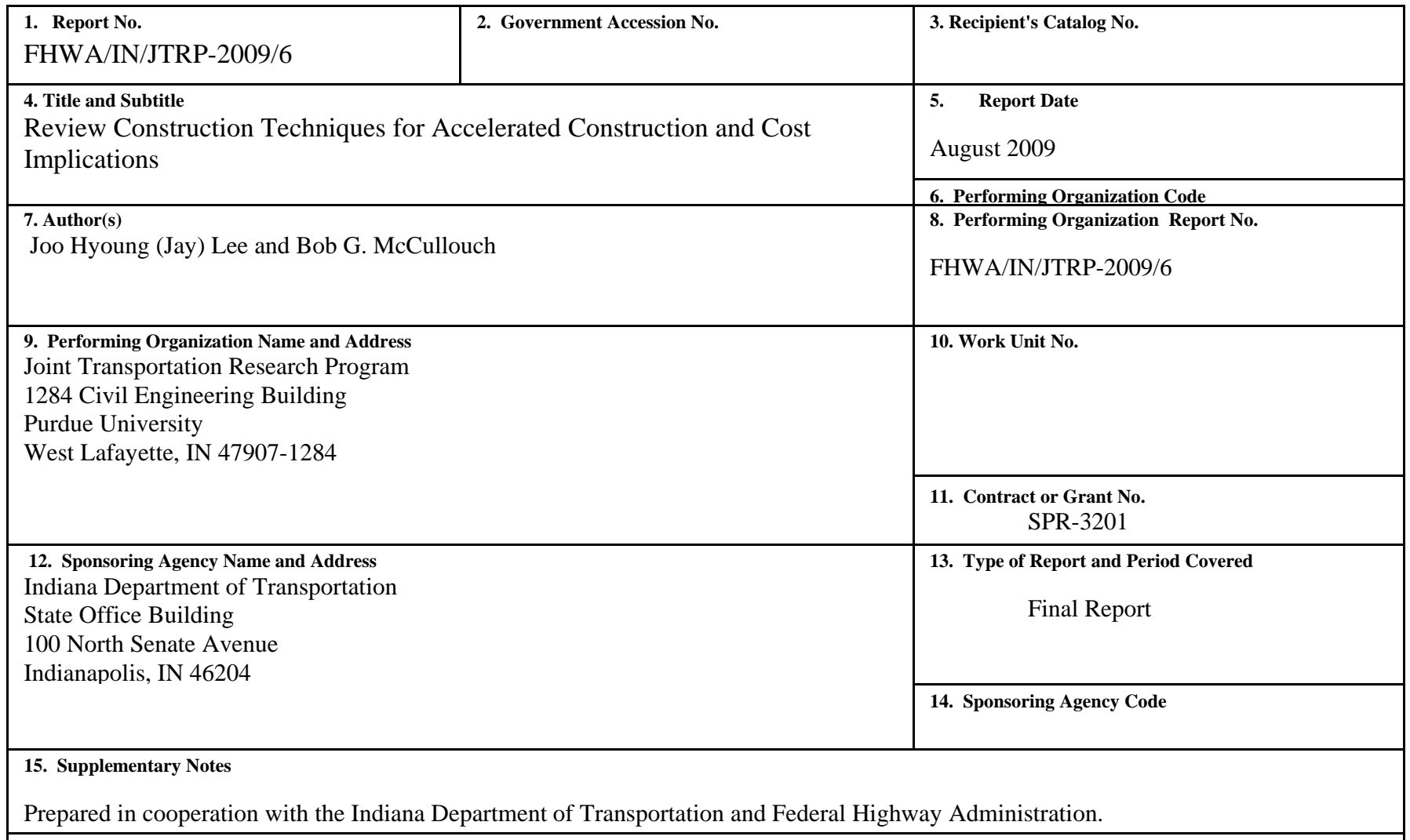

\section{Abstract}

Transportation construction activities on heavy traffic routes can be very disruptive to the system users due to lane closures, construction traffic, or reduced speed zones. Besides the driving public, local businesses are also affected by noise and air pollution, loss of access, or changing access routes. Thus, it is apparent that minimizing construction time will lessen these impacts. The primary objectives of this project are to explore some alternative methods to expedite construction time for particular project types whereby mitigating disruptions to the traveling public and to identify construction activities that can be accelerated by those selected methods. To accomplish these objectives, this project evaluated state-of-the-art construction techniques for accelerating processes at the jobsite by investigating practices of other transportation agencies (DOT) and their cost implications.

\footnotetext{
17. Key Words

Accelerated Construction Techniques, Roller Compacted Concrete, Welded Wire Reinforcement, Accelerated Bridge Construction, Innovative Contracting
}

18. Distribution Statement

No restrictions. This document is available to the public through the National Technical Information Service, Springfield, VA 22161

$$
\begin{gathered}
\text { 19. Security Classif. (of this report) } \\
\text { Unclassified }
\end{gathered}
$$

$$
\begin{gathered}
\text { 20. Security Classif. (of this page) } \\
\text { Unclassified }
\end{gathered}
$$

\begin{tabular}{|c|c|}
\hline 21. No. of Pages & 22. Price \\
102 & \\
\hline
\end{tabular}

Form DOT F 1700.7 (8-69) 


\section{Table of Contents}

Background and Problem Statement.............................................................................. 1

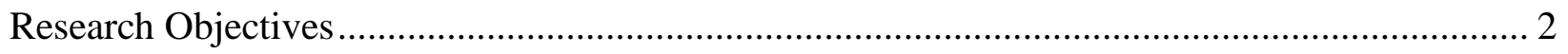

Advanced Construction Techniques for Accelerating Construction ............................................. 4

Portland cement concrete pavement (PCCP) with admixtures ................................................. 4

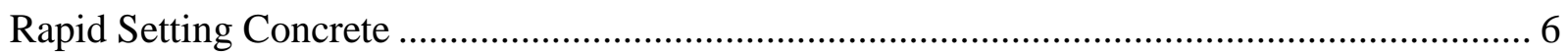

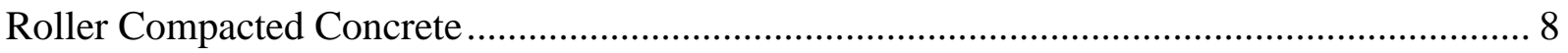

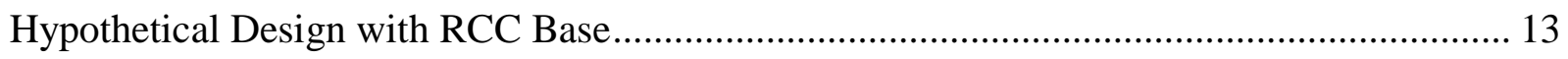

Galvanized Welded Wire Reinforcement Instead of Conventional Rebar ............................... 17

Precast Modular Concrete Systems ................................................................................. 20

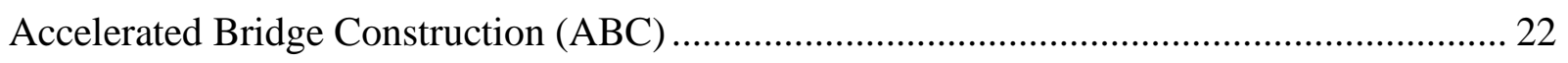

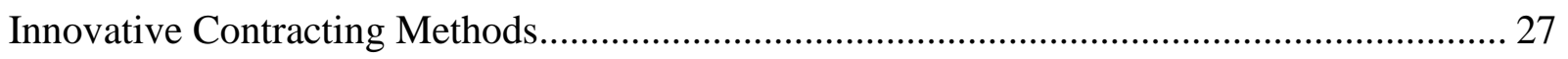

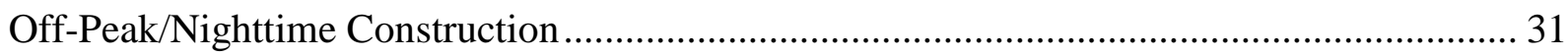

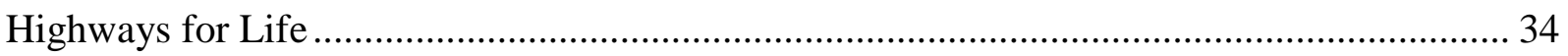

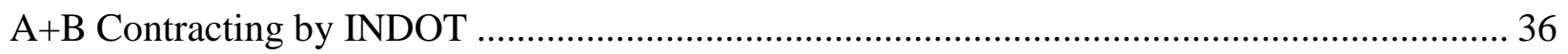

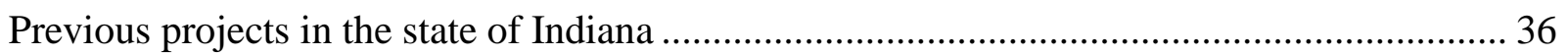

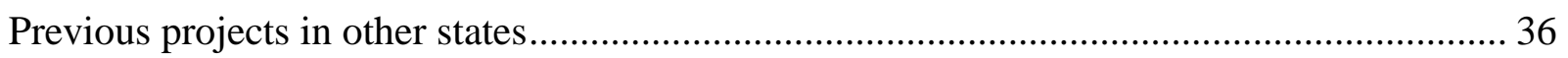

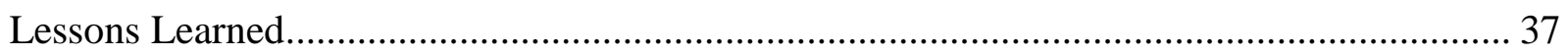

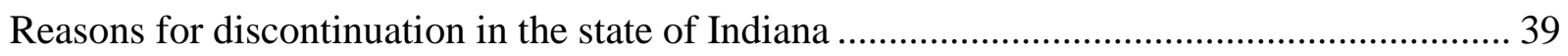

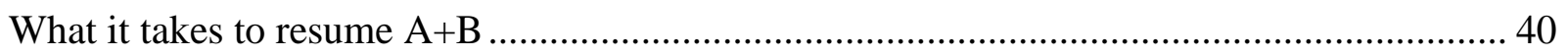

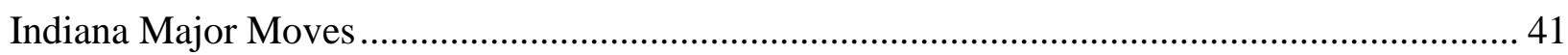

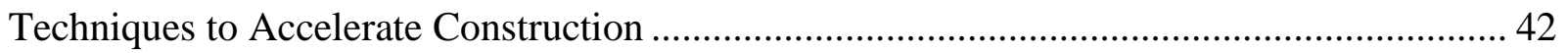

Major Activities in Indiana Major Moves ............................................................................ 43

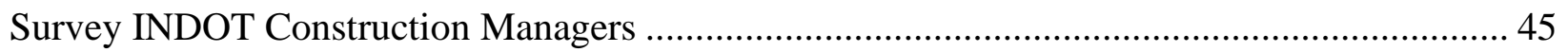

Survey Other State Transportation Agencies........................................................................... 46

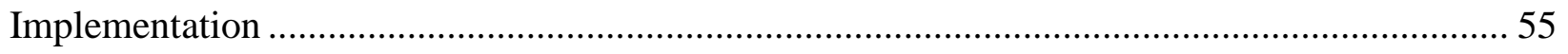

Time Comparison

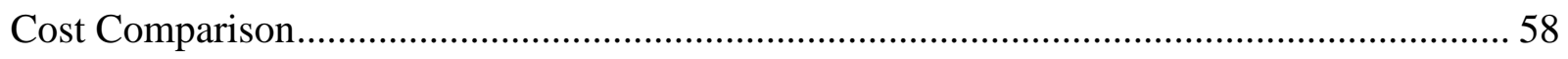

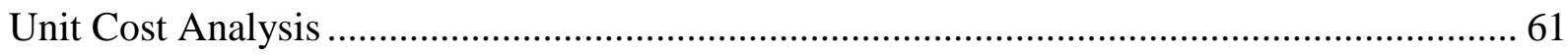

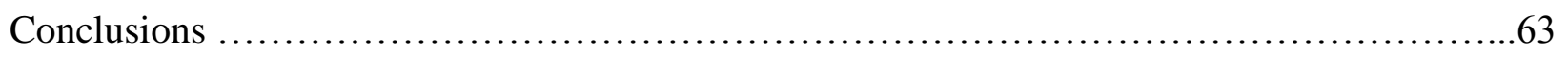

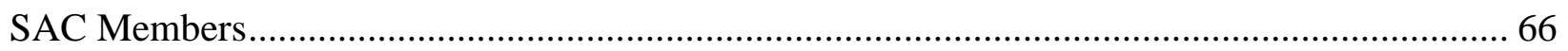




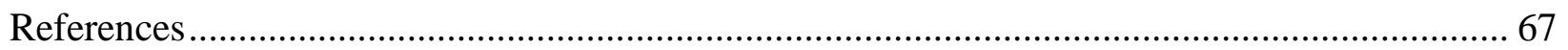

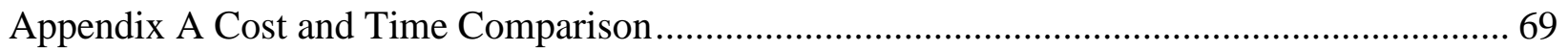

Appendix B INDOT Project Managers and Designers Survey Questionnaire .......................... 73

Appendix C State Transportation Agencies Survey Questionnaire ......................................... 74

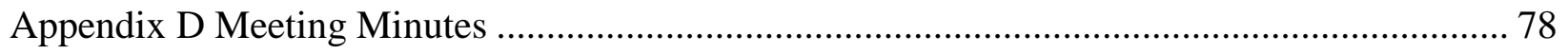

Appendix E Georgia Department of Transportation Roller Compacted Concrete Pavement ...... 86

Appendix F Residential Pavement Design Options for Columbus, Ohio........................ 97

Appendix F Welded Wire Reinforcement Transportation specifications......................116 


\section{List of Tables}

Table 1 PCC versus MMA (Source: Mindess et. al.) …………………….............................. 5

Table 2 Ohio Department of Transportation Design Category................................................... 13

Table 3 Constructed Thickness Comparison (RCC Base and HMA) ......................................... 14

Table 4 Unit Cost Comparison (RCC Base and HMA) ........................................................... 15

Table 5 Constructed Thicknesses and Unit Cost Comparison (RCC Base and PCCP)................ 17

Table 6 Matrix Questions for a Prefabricated Bridge (FHWA, 2005) ………………................. 25

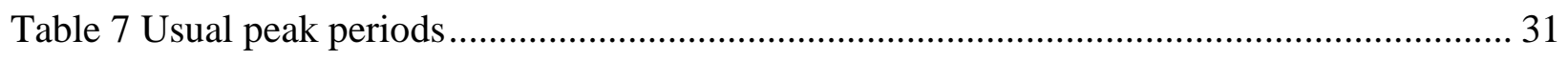

Table 8 Indiana Major Moves.......................................................................................... 43

Table 9 State Transportation Agencies Survey Result ……...................................................... 47

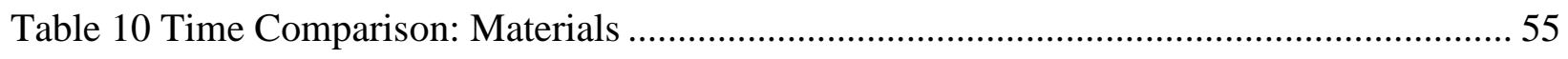

Table 11 Time Comparison: Bridge Construction ..................................................................... 57

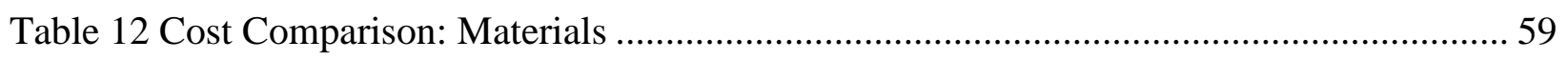

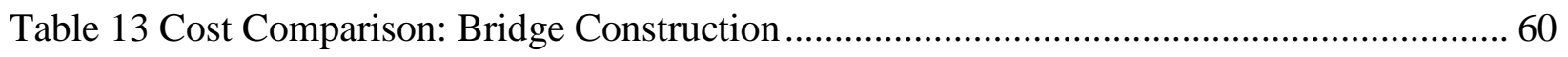

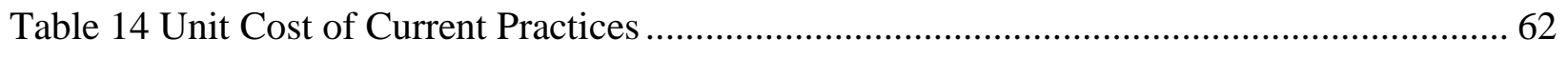

Table 15 Comparison of Current Practices and Accelerating Techniques .................................... 63 


\section{List of Figures}

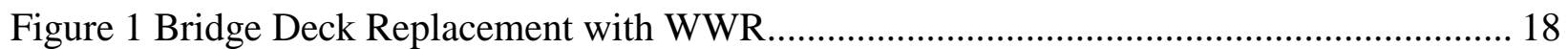

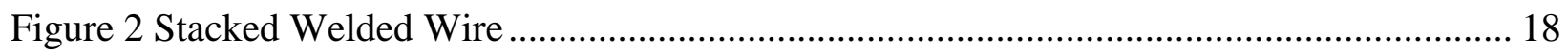

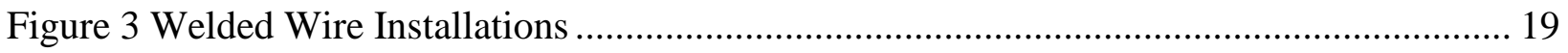

Figure 4 Self Propelled Modular Transporters (SPMT) (FHWA, 2007) …………….................. 23

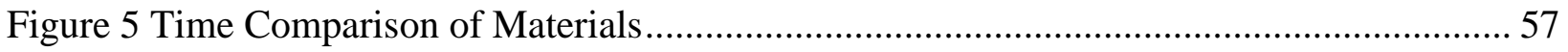

Figure 6 Time Comparison of Bridge Construction Approaches ................................................ 58

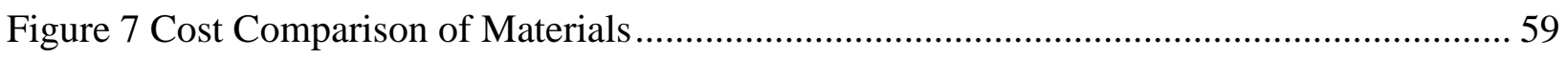

Figure 8 Cost Comparisons of Bridge Construction Approaches................................................. 60 


\section{Background and Problem Statement}

In 1956 the federal government set an energetic goal of paving 42,000 miles of interstate highway by 1975. At that time, the federal government was more interested in quantity rather than quality. Interestingly, the federal grant stated that the federal government would construct the highway system and the states would be responsible for the maintenance. States were not allowed to have any input into the design of the pavement because the federal government reasoned that, if the highway was designed better, the cost for that highway construction would increase. In other words, the federal government encouraged less cost on that highway construction; and in effect the federal government would be willing to assist the state in the maintenance at a later time. This was known as the main reason for the 25 -year design life for the interstate system built in 50's through 70's, although it is now extended to well over 50 years with new engineering knowledge and techniques. As the highway system ages, more resources will be needed for repair, rehabilitation and reconstruction of existing roadways. This includes more time on those construction activities that disrupt the traffic users and local businesses.

In addition, being used for over 50 years, the interstate system is now transporting more people and more shipment than it was ever thought possible. Study says the volume of traffic on the US highway system has increased by approximately $75 \%$ in the past 30 years while the total mileage added to the same highway system has increased by less than 5\%. These facts assist FHWA in estimating that a majority of the highways, especially in urban areas, will be at capacity within the next 12 years. This has placed an increasing demand upon all of the roadways, especially the highways, and required expansion of their capacities. Although highway construction projects are inevitable and a growing part of our daily lives, it is still required to minimize troubles to the public. By and large, transportation construction activities on heavy traffic routes can be very disruptive to the system users due to lane closures, construction traffic, or reduced speed zones. Besides the driving public, local businesses are also affected by noise and air pollution, loss of access, or changing access routes. Thus, it is apparent that minimizing construction time will lessen these impacts. 


\section{Research Objectives}

The primary objectives of this project are to explore some alternative methods to expedite construction time for particular project types whereby mitigating disruptions to the traveling public and to identify construction activities that can be accelerated by those selected methods. To accomplish these objectives, this project evaluated state-of-the-art construction techniques for accelerating processes at the jobsite by investigating practices of other transportation agencies (DOT) and their cost implications. Detailed project activities are as follows.

- First, a literature review on construction methods and techniques to better handle those disruptions described earlier was performed. The evaluation of alternatives includes construction methods, equipment, materials, and labor needed. Their associated costs and time are compared with those for the current practices because those are considered primary decision makers at the project planning stage.

- Second, current INDOT highway projects were classified into several main categories. This segregates activities in each category and determines their typical contract time, production rate, and unit cost to be later compared with the accelerating construction methods.

- Third, INDOT construction project managers/engineers were surveyed to identify which construction activities in each category cause the most disruptions to transportation system users and the surrounding areas.

- Fourth, other state transportation agencies were surveyed to collect information on their current practices and their lessons learned such as benefits and liabilities. This included an in-depth review of their practices that have been performed to minimize disruptions to transportation system users while maintaining constructability. The survey also inquired if they apply any newer technologies and products to accelerate construction. 
- Last, several recommendations were made to develop an implementation plan for the suggested techniques along with their time and cost options to be later referred to by planning, design division and design consultants. This information will be requested for inclusion into the project management PDP (or planning and development phase) process so it can be considered during the planning and development phase. 


\section{Advanced Construction Techniques for Accelerating Construction}

In this study, the following methods to accelerate construction activities were explored for the planning and design phases of INDOT transportation construction projects.

- $\quad$ PCCP with admixture

- Rapid setting concrete

- Roller compacted concrete

- Welded wire reinforcement for bridge decks

- Precast concrete modular construction

- Accelerated bridge construction

- Innovative contracting methods

- Off-site substructure construction

- Highways for Life program

While the first five topics discussed innovative construction materials, the next two (off-peak construction and innovative contract methods) focus on procedures and planning. The last topic, Highways for Life, is a relatively new program by the FHWA to advance innovative, alternative methods of accelerated construction. Portland cement concrete pavement (PCCP) and bituminous pavement (asphalt pavement) are the two most common types of conventional pavement.

$\underline{\text { Portland cement concrete pavement (PCCP) with admixtures }}$

Admixtures are any materials added to the cementitious mix other than cement, aggregates, water, or fibers. They are added prior or during the mixing and are used to

- $\quad$ Speed up the setting time

- Slow down the setting time

- Increase the workability

- Improve the strength of the concrete mix

- Reduce cement or water content

- Frost and chemical resistance. 
Admixtures are usually added at the plant when the truck is being loaded with the cement mixture. It is common for PCCP to contain a combination of many admixtures, each one countering a particular drawback of another. They are either chemicals or minerals, many of which are compatible with one another. These admixtures will increase the strength by approximately $25 \%$ within the first 3 days.

Table 1 compares the properties of PCCP to the most common type of epoxy cement used in highway reconstruction: Methyl Methacrylate (MMA). Appendix A shows the average cost as well as several advantages and disadvantages of each admixture.

Table 1 PCC versus MMA (Source: Mindess et. al.)

\begin{tabular}{|l|c|c|c|c|c|}
\hline \multirow{2}{*}{\multicolumn{1}{|c|}{ Property }} & \multicolumn{4}{c|}{ PCCP (type I \& II) } & MMA \\
\hline & \multicolumn{5}{c|}{ Unit of measure } \\
\cline { 2 - 7 } & day 1 & day 3 & day 7 & day 28 & $\begin{array}{c}\text { day 1 } \\
\text { (4 hours @ 70 deg F) }\end{array}$ \\
\hline Compressive strength (MPa) & 14.9 & 25 & 32.5 & 41.6 & $55-62(8000-9000 \mathrm{psi})$ \\
\hline Flexural strength (MPa) & 2.32 & 3 & 3.42 & 3.87 & $13-17(2000-2500 \mathrm{psi})$ \\
\hline Linear shrinkage & \multicolumn{7}{|c|}{$<.4 \%$} & $<.2 \%$ \\
\hline Tensile strength & \multicolumn{3}{|c|}{ No test for tensile strength available in North America } \\
\hline Pot life (@70degree F) & $\begin{array}{c}60 \\
\text { min. }\end{array}$ & \multicolumn{7}{c|}{ N/A } & 24 min \\
\hline
\end{tabular}

* No admixture is added.

In Table 1 and Appendix A, it should be noted that the tables show only the admixtures discussed in this report. Notice that there are many different types of bituminous pavement (Indiana DOT alone lists 74 different unit prices for HMA) and the unit price for PCCP does not include any admixtures. Many times PCCP is placed containing a variety of admixtures depending upon the work zone conditions or the owner's specifications. It affects the price. Thus, the costs mentioned are for that admixture only. 
The most common accelerator in this category is calcium chloride $\left(\mathrm{CaCl}_{2}\right)$. However, as one would correctly assess, this admixture has a remarkable drawback in that it is firmly limited to concrete without steel reinforcing rod. Studies have shown that, especially in moist or humid environments, corrosion of imbedded metal is accelerated, even though several admixtures (silica fume for example) help protect the steel rods from this corrosion. In addition, Calcium Chloride should not be used in very hot weather or in prestressed concrete because it will increase the internal temperature significantly, and therefore the overall strength of the concrete structure diminishes. However, this increase in temperature aids in cement that is poured in colder non-freezing temperatures. The percentage of shrinkage increases when it is added to concrete, but this shrinkage can be minimized with the addition of Sodium Sulfate $\left(\mathrm{Na}_{2} \mathrm{SO}_{4}\right)$.

There are other non-chloride accelerators that have been developed because of this drawback of Calcium Chloride. Triethanolamine $\left(\mathrm{NC}_{2} \mathrm{H}_{4} \mathrm{OH}_{3}\right)$ is perhaps the most common, but Calcium Formate $\left[\mathrm{Ca}(\mathrm{OOOCH})_{2}\right]$, Calcium Nitrite $\left[\mathrm{Ca}\left(\mathrm{NO}_{2}\right)_{2}\right]$, and Calcium Thiosulfate $\left(\mathrm{CaS}_{2} \mathrm{O}_{3}\right)$ are also acceptable. However, Calcium Formate and Calcium Thiosulfate are rarely if at all used within the construction field. They are more commonly found in consumer products and agriculture. It must be pointed out, that larger amounts of non-chloride admixtures must be added to the cement mixture to achieve the same results as the chloride based admixture because they are not as effective.

\section{$\underline{\text { Rapid Setting Concrete }}$}

The term "rapid setting concrete" refers to a concrete like substance that reaches its full hardness and structural strength very quickly. For this reason it is an ideal repair on bridge decks or other work where time is of the essence and detours are not an option, e.g. busy airport runways, downtown parking garages. Rapid setting concrete resembles PCCP in appearance, but it is not a cementitious product. It is rather epoxy mixed with aggregate. The main difference from PCCP is that it is able to set up and reach full structural strength within a few hours, even in temperatures below $40^{\circ} \mathrm{F}$. If the directions are strictly followed, the various types of epoxy have great resistance to oil, water or such other chemicals as acids. The biggest drawback is its cost 
since these types of cement can cost well over $\$ 100.00 / \mathrm{ft}^{3}$. Still, if time is an overriding concern, then it might be justifiable in using an epoxy based product.

Rapid setting concrete is often referred to as epoxy cement, which is generally used as a thin overlay (often about 1/2-3/4 inch) on bridge decks or as patch filler. Traditional bridge deck overlays consist of milling off the top 3-4 inches of the bridge deck, repairing the rebar and then pouring a new layer of PCCP. Using epoxy cement on an overlay can eliminate the milling of the top layer, and instead jack hammering out the rebar that needs to be repaired and then proceeding to the overlay. Often a layer of semi-fine aggregate such as blast furnace coal slag is broadcast on top of the epoxy cement for friction. An entire section or lane of a bridge can be completed quickly and reopened within a couple of hours.

A good example of this technique was the rehabilitation of I-64 bridge over the Mississippi River in St. Louis, Missouri. The existing deck was concrete with an asphalt overlay which had numerous potholes, corrosion to the reinforcing steel, and serious cracking and spalling. Because the bridge is vital and has a great deal of daily traffic volume, the contractor wanted to finish the project as soon as possible. Thus, the contractor poured a 1/8" overlay with epoxy cement and added an aggregate overlay. They were able to complete the project over a period of 4 weekend nights, with partial lane closures during the project, and reopening the lanes each morning. (Gale Group, 2003)

Although different epoxy based concrete has different characteristics and applications, there are many similarities. Once the epoxy has set, it has a very good or excellent water resistance which translates to a high resistance to the freeze-thaw cycle. Wear resistance in all epoxy concrete is good to excellent. However, the mixing process is extremely delicate. Most formulas have to be mixed precisely, are extremely flammable, and they have a strong toxic order. During the mixing and placing process they are very sensitive to moisture so the substrate and the aggregate must be dry, but they will bond to any type of substrate. As previously mentioned this can be fairly expensive. 
There are three different forms of epoxy based concrete that are primarily used in construction today: Methyl Methacrylate (MMA), High Molecular Weight Methacrylate (HMWM), and

polyesters. MMA is the most widely used because it is the original epoxy based cement and easy to use. Although it has moderate shrinkage (>.2\%), a strong odor and highly flammable substances, it will reach a structural strength of 8,000 psi after one hour at $70^{\circ} \mathrm{F}$. Table 1 shows a comparison with conventional concrete.

HMWM, on the other hand, has a relatively low odor and low flammability which makes it much more conducive to the construction trades, especially in enclosed areas. It is similar to MMA in other characteristics, but is more expensive. Polyesters are the least expensive epoxy with half the cost. Because of this they are widely used, but they have significant amount of shrinkage during the setting although anti-shrinkage agents may help. Their primary uses include crack repairs and seal coating. They are not as quick and the strength is not as great, but they are a very good, less expensive alternative. Most polyester needs a primer to help in bonding both aggregate and substrate. Fourth epoxy-urethanes are also available, but it is mainly suited for seal coating and waterproofing, and doesn't have any real input in roadway construction. For a further comparison of the pros and cons of the variety of rapid setting or epoxy based concrete refer to Appendix A.

\section{$\underline{\text { Roller Compacted Concrete }}$}

Roller compacted concrete pavement (RCCP) is a zero slump portland cement concrete pavement that is laid either with bituminous asphalt pavement equipment or common earthmoving equipment. It is then immediately compacted with vibratory and rubber tire rollers. As a rule, RCCP consists of $75-85 \%$ aggregate with a maximum size of $3 / 4$ inch or $19 \mathrm{~mm}, 9$ to $18 \%$ cement, and 4 to $7 \%$ water. This mixture resembles wet sand. With the proper equipment, RCCP can be laid in layers up to 10 inches thick and 24 feet wide, but the width is only limited by the equipment width. RCCP is an off-highway, low speed pavement and is also referred to as rollcrete or soil-cement. It does not have the smooth finish that a traditional PCCP system possesses; it has on the other hand a rough, bumpy surface that cannot be smoothened with a 
trowel. As a general rule it is allowed to crack naturally, although control joints are sometimes cut in.

Roller compacted concrete is a relatively new product that was invented in 1976 in Canada as low cost road pavement system that could handle the heavy loads of the logging trucks and equipment, and could stand up to the rigorous weather of the Canadian winters. It has found a niche in container ports, rail yards, truck terminals, and other industrial yards which are subject to heavy equipment such as forklifts and cranes. It has also been used almost exclusively in gravity dam construction by the U.S. Army Corp of Engineers. Because the cost of labor is extremely low, it can compete with bituminous pavement or hot mix asphalt (HMA) as far as its initial cost, and when one factors in long term benefits, it will surpass asphalt. In Canada, under harsh weather conditions and heavy traffic usage, roller compacted concrete pavement has held up similarly in comparison with conventional PCCP. For this reason, many industrial companies choose RCCP instead of HMA or PCCP for the pavement of their yards or lots. Some cities in the U.S. use a composite system where RCC provides the base with a thin top layer of asphalt. Columbus, Ohio is probably on the forefront with many streets and intersections paved with RCCP or a combination of RCCP and flexible pavement (Portland Cement Association, 2008). It is not known how the construction companies deal with the reflection cracks in the flexible pavement.

RCCP is an economically attractive system when compared to conventional PCCP or bituminous pavement. Its advantages include costs, rapid construction, and proven performance. The U.S. Army Corp of Engineers assess that the cost of RCC is approximately 25 to $50 \%$ less than traditional PCCP. In fact, according to 1998 price, the cost to lay $200,000 \mathrm{~m}^{3}$ is about $\$ 35 / \mathrm{m}^{3}$, about half of what it costs to lay conventional PCCP (US Amy Corp of Engineers, 2000). This factors in the cost of the aggregate and the cement, complexity of the project, reduction in manpower, no forms or finishing, no steel reinforcing or dowels needed, and no formed or sawed joints needed. In the southwest United States where water is always at a premium, the reduction of water is an important cost saving. 
Since RCC is laid like asphalt, the reduction in manpower to place and remove the concrete forms is a large time saver. Also it can be laid under operating traffic conditions. The flexural strength reaches 400 psi within 24 to 48 hours, and in some instances RCC can support light traffic sooner. If the plans call for the concrete depth to be more than 10 inches then two pours are necessary, with the top pour being able to be made immediately after compaction of the first layer. Since no joints are needed, RCC does tend to do better if it is laid in one continuous pour. If joints are desired, they may be cut after the first hour and within the first 24 hours. As a general rule longitudinal and transverse joints are not required. However, if transverse joints are desired, they should be spaced 50 to $75 \mathrm{ft}$ apart.

Roller compacted concrete has the same properties as conventional concrete. Canadian officials report that after ten years, roller compacted concrete performs like conventional portland cement concrete and has held up very well. Any differences that may be encountered would be due to the lower water content, differences in aggregate, or differences in the field control of the cementitious mix.

To date there has been very few projects where RCCP has been used in highway construction. Columbus, $\mathrm{OH}$ and Atlanta, GA have several completed composite roadway systems since it was introduced in 2001. In some instances, roller compacted concrete is used as a base for a bituminous asphalt overlay. This approach works well on busy streets and intersections where access to businesses cannot be restricted. The following shows example projects to facilitate understanding of RCC pavement construction.

\section{Georgia Examples}

Although many other cities have adopted RCCP for their streets, and there is a record of it being used on highway shoulders on I-285 in Atlanta, GA. The following is the detailed project information reported by the Georgia Department of Transportation. The project cost are from 2006. See Appendix E for a detailed design specification from the Georgia Department of Transportation. 
Project Scope: 6.2 miles of shoulder reconstruction with RCC, Continuous Reinforced Concrete slab installation, various bridge joint replacements, and safety upgrades including guardrail, recovery zone improvements, rumble strips and wet reflective striping

- Project Authorized: Nov. 29, 2005

- Contractor: APAC - Southeast

- Subcontractor: A. G. Peltz - Birmingham, AL

- Total Original Contract Price: $\$ 30,842,204$

- Start Date: January 19, 2006

- Scheduled Completion Date: November 30, 2006

- Roller Compacted Concrete (RCC) - \$166.66/yd ${ }^{3}$

- Continuous Reinforced Concrete (CRC), High Early Strength (HES) - \$86.00/yd ${ }^{2}$

- Continuous Reinforced Concrete (CRC), Plain - $\$ 62.40 / \mathrm{yd}^{2}$

Another project in Georgia is a different RCC application. As it is noticed, project costs are different from the previous example because of different job conditions.

Project scope: Interchange reconstruction and widening for additional lanes, grading, drainage, base, plant mix paving, ramp reconstruction and construction of collector distributor ramp lanes also includes construction of 3 bridges and approaches.

Contract Specs: New access point to Interstate at SR 13 to form CD lanes. RCC shoulders 7.5 inches thick on inside of travel lanes to support traffic during staged construction and final shoulder

- Contractor: E. R. Snell - Snellville, Georgia

- Subcontractor: A.G. Peltz - Birmingham, Ala.

- Construction began June 27, 2006

- Completion date July 31, 2009

- Total Project Cost $\$ 74,611,684.92$

- $\mathrm{RCC}-\$ 32.00 / \mathrm{m}^{2}$ (or $\$ 26.67 / \mathrm{yd}^{2}$ ) 


\section{Ohio Examples}

During the summer of 2008, the project team contacted a representative of Nick Savko who performed an urban arterial street in Columbus, $\mathrm{OH}$. Some other projects they did in the past using RCC were residential streets, a rail yard, a trucking terminal, etc. They said, in general, light traffic is allowed after 24 hours and multiple axle trucks in three days with RCC.

An interview on July 30, 2008 revealed, however, Nick Savko mainly uses a composite system where RCC is the base and a top layer (2-3") of HMA is used. They said it can be a perfect base material for the following reasons.

1. Cost; with the cost of oil skyrocketing asphalt is almost becoming cost prohibitive. On the scale, HMA is the most expensive to lay, conventional PCCP is next and RCC is the most inexpensive and remains so (less labor, no finishers).

2. RCC as one can imagine is a much better base than the tradition gravel/ HMA base layer/ HMA intermediate layer.

3. There are reflective cracks but RCC has much lower rate of cracking because of its low water content. As the water in tradition PCCP evaporates, the PCCP shrinks and cracks. Nick Savko does saw cut the RCC every 30' and also saw cuts the HMA above, then immediately seals the cuts.

4. There are not really any potholes, and if one does appear, it will only be 2" and that can be milled and replaced. (Columbus requires a top layer of 2", some of the surrounding communities require 3 ”.)

Based on the interview, RCC could be a good cost saver as a base material, but it is still not desirable as the top layer of the main lane because of its roughness. Thus, another option being considered was RCC pavement on shoulders where one does not need a smooth surface as required on the driving lanes. In fact, one of the SAC members suggested placing RCC on shoulders might shorten overall construction time. However, since it is an easier practice to pour 
concrete on the main lane and shoulder together, this option also may not be practical in that sense.

As far as production rate, Nick Savko placed on the average of 1,600 $\mathrm{yd}^{3}$ of RCC per 12-hour day in an intermodal project for the Norfolk Southern RR. Thus, in a typical project, it is suggested to apply 100 to $150 \mathrm{yd}^{3}$ per hour, considering a typical pug-mill capability of producing $200 \mathrm{yd}^{3}$ per hour. However, it turned out difficult to maintain this rate on a daily basis because of variable job conditions.

\section{Hypothetical Design with RCC Base}

Columbus, $\mathrm{OH}$ has been at the forefront of using $\mathrm{RCC}$ as a base in their roads, which is called a composite system. The practice of using a composite system has been a commonplace for the last seven years. On streets that are built using a composite system, the city requires a concrete base and an intermediate layer of either 1.5 in. or 1.75 in hot mixed, hot laid asphalt and a top layer of $1.25 \mathrm{in}$. hot mixed, hot laid asphalt. The main difference is dependent upon the Average Daily Traffic (ADT) with a percentage of trucks, shown in Table 2, as prescribed by Ohio Department of Transportation (ODOT). The make-ups of the streets are dependent on one of the four following categories (City of Columbus 2007):

Table 2 Ohio Department of Transportation Design Category

\begin{tabular}{|c|l|}
\hline Category & \multicolumn{1}{c|}{ Description } \\
\hline I & $\begin{array}{l}\text { ADT of less than 500 units (such as residential cul-de-sacs and streets with } \\
\text { no possibility of expansion) }\end{array}$ \\
\hline II & $\begin{array}{l}\text { ADT between 500 and 1500 (short streets connecting other streets with, } \\
\text { again, no possibility of expansion) }\end{array}$ \\
\hline III & ADT between 1500 and 3500 (all other residential streets) \\
\hline IV & ADT greater than 3500. (non-residential streets) \\
\hline
\end{tabular}

There is also a difference between standard subgrade and soil-stabilized subgrade. Concrete must have a minimum of 2500 psi after 28 days for the first two categories and 3000 psi after 28 
days for non-residential and heavy traffic residential streets. The HMA layers are the same thickness throughout the first three categories. The intermediate and top layers of hot mixed asphalt to be 1.5 and 1.25 respectively. In the first category, regardless of the subgrade, the RCC base is specified to be 5 in. The second category requires the RCC to be 5.5 inches on standard subgrade and 5.25 inches on soil stabilized subgrade. The third category calls for the depth or the concrete base to be 7.0 inches on standard soils and 6.5 inches on stabilized soils. Nonresidential streets specify that the concrete base be 8 inches and the layers of HMA to be 1.75 inches (intermediate) and 1.25 inches (top). The difference in the subgrade is irrelevant for this purpose. Table 3 is from the City of Columbus, Ohio Design Standards and shows the comparison of constructed thickness for the different pavement types.

Table 3 Constructed Thickness Comparison (RCC Base and HMA)

\begin{tabular}{|c|c|c|c|c|c|c|c|}
\hline Category & \multicolumn{2}{|c|}{ I } & \multicolumn{2}{|c|}{ II } & \multicolumn{2}{|c|}{ III } & IV \\
\hline Base Type & Flex $^{2}$ & Comp $^{3}$ & Flex & Comp & Flex & Comp & \multirow{5}{*}{$\begin{array}{l}\text { Use DOT } \\
\text { design } \\
\text { method for } \\
\text { ultimate } \\
\text { design } \\
\text { ADT }\end{array}$} \\
\hline Top layer & $1.25^{4}$ & 1.25 & 1.25 & 1.25 & 1.25 & 1.25 & \\
\hline Intermediate layer $^{1}$ & 1.5 & 1.5 & 1.5 & 1.5 & 1.5 & 1.5 & \\
\hline Base layer & 3.25 & \multirow{2}{*}{5} & 3.75 & \multirow{2}{*}{5.5} & 5.25 & \multirow{2}{*}{7} & \\
\hline Subbase layer & 6.0 & & 6.0 & & 6.0 & & \\
\hline Constructed thickness & 12.0 & 7.75 & 12.5 & 8.25 & 14.0 & 9.75 & \\
\hline Thickness Difference & 4.25 & & 4.25 & & 4.25 & & \\
\hline
\end{tabular}

${ }^{1}$ HMA: two-layer asphalt surface with standard soil

${ }^{2}$ Flex: Flexible asphalt with compacted aggregate base

${ }^{3}$ Comp: Composite asphalt with RCC base

${ }^{4}$ Unit: inches

Overall, pavements using RCC as base can be 4.25" thinner than pavements with compacted aggregate base. Also, Table 4 shows a cost comparison based on the unit costs of aggregate base 
and RCC base: $\$ 50 / \mathrm{yd}^{3}$ and $\$ 73 / \mathrm{yd}^{3}$ individually. The table shows that using RCC as base lowers overall pavement cost.

Table 4 Unit Cost Comparison (RCC Base and HMA)

\begin{tabular}{|c|c|c|c|c|c|c|c|}
\hline Category & \multicolumn{2}{|c|}{ I } & \multicolumn{2}{|c|}{ II } & \multicolumn{2}{|c|}{ III } & IV \\
\hline Base Type & Flex & Comp & Flex & Comp & Flex & Comp & \multirow{6}{*}{$\begin{array}{l}\text { Use DOT } \\
\text { design } \\
\text { method for } \\
\text { ultimate } \\
\text { design } \\
\text { ADT }\end{array}$} \\
\hline Base layer & 3.25 & \multirow{2}{*}{5} & 3.75 & \multirow{2}{*}{5.5} & 5.25 & \multirow{2}{*}{7} & \\
\hline Subbase layer & 6.0 & & 6.0 & & 6.0 & & \\
\hline Total base thickness & 9.25 & 5 & 9.75 & 5.5 & 11.2 & 7 & \\
\hline Cost $\left(\$ / y d^{2}\right)$ & 12.85 & 10.14 & 13.5 & 11.15 & 15.6 & 14.19 & \\
\hline Cost difference $\left(\$ / y d^{2}\right)$ & - & 2.71 & - & 2.39 & - & 1.44 & \\
\hline
\end{tabular}

The use of RCC within Columbus has been on low volume roads. What design method did the City of Columbus use to determine pavement thicknesses? One of the design options for a street with low Average Daily Traffic (ADT) is a composite section, which consists of a hot mix asphalt (HMA) top layer placed over a roller compacted concrete (RCC) base. The design method is the same as the rigid concrete pavement for low-volume roads. The City of Columbus, $\mathrm{OH}$ followed the AASHTO 93 design guide and required 5-inch RCC base as a minimum requirement (See rigid pavement design method on pages II-82 to II-86 in Chapter 4 LowVolume Road Design). 2 to 3-inch HMA top layer is then added strictly for ride quality. Although this top layer does add some strength, it is negligible. Thus, the added strength is not included in the calculations. According to Dr. Abdulshafi of the Columbus Public Works Department, this design method was originally developed for residential pavement design, but they have started looking at arterial and main streets within the last couple of years.

The current design method was recently modified by the City of Columbus (Nick Savko and Sons 2004) by increasing the minimum thickness of the RCC base from 5" to 6". The changes are made to enhance the strength. City engineers preformed a split test after 26 hours and found that the composite section has over 700 psi. Testing at 28 days also shows that the composite 
section is comparable to traditional PCCP. They have also found that the composite section has the strength to support pedestrian traffic after 8 hours and limited vehicular traffic after 26 hours. Appendix F is a report developed by Michael I. Darter Ph.D., P.E. that describes Residential Pavement Design Options for Columbus, Ohio.

Another question of composite roadway system can now be how RCC would pair with Portland Cement Concrete Pavement (PCCP). After literature review, there does not appear to be any studies on a main lane pavement with a composite system of RCC as a base and PCCP as a top layer. This may be due to the fact that it is uncommon, while the idea would not be uncommon.

Thus, in looking to formulate a RCC/PCCP composite roadway, the following parameters are assumed for the purpose of hypothetical design comparison:

- $\quad$ Loss of support (LS): 1.0

- $\quad$ Roadbed soil resilient modulus: 20,000 psi

- Concrete elastic modulus: 4,000,000 psi

- 8 " subbase thickness

- Subgrade depth: semi-infinite
- Mean concrete modulus of rupture: 650 psi

- $\quad$ Load transfer coefficient: 3.2

- Drainage coefficient: 1.0

- Reliability: $95 \%$

- Standard deviation: 0.3

- $\quad$ ESAL: 2,000,000

Using these parameters and the AASHTO concrete pavement design manual, a projected slab thickness is computed 7.5 inches compared with unbound granular base which needs 8.5" concrete pavement layer. Thus, based on the comparison, RCC base makes the PCCP top layer 1" thinner than regular aggregate base. The following table shows a unit cost comparison assuming the unit costs of PCCP, unbound aggregate, and RCC base: $\$ 158.1 / \mathrm{yd}^{3}, \$ 50 / \mathrm{yd}^{3}$, and $\$ 73 / \mathrm{yd}^{3}$ respectively. Theoretically using RCC as base would be more expensive. 
Table 5 Constructed Thicknesses and Unit Cost Comparison (RCC Base and PCCP)

\begin{tabular}{|c|c|c|}
\hline Base Type & Unbound Aggregate & RCC Base \\
\hline Top layer (inches) & 8.5 & 7.5 \\
\hline Base layer (inches) & 8.0 & 8.0 \\
\hline Cost $\left(\$ / \mathbf{y d}^{2}\right)$ & 48.44 & 49.16 \\
\hline Cost difference $\left(\$ / \mathbf{y d} \mathbf{d}^{\mathbf{2}}\right.$ & - & $\mathbf{0 . 7 2}$ \\
\hline
\end{tabular}

Galvanized Welded Wire Reinforcement Instead of Conventional Rebar

Ohio Department of Transportation (ODOT) recently completed a bridge deck replacement on SR 185 in Miami County utilizing galvanized, prefabricated wire reinforcement mats instead of conventional epoxy coated tied rebars. The 238.71' long, 31.5' wide bridge over the Stillwater River was in need of a deck replacement. Rather than using half width construction with traffic lights, it was determined to close the road completely and minimize closure time to 45 days by using a prefabricated reinforcement mats.

The mats for this project were furnished full width of the bridge in panels 31' long and 11'-9" wide. A 2'-7'" length of the longitudinal wires extended out to allow for splicing to the adjacent section of mat. The bridge is skewed 20 degrees and therefore the end panels of the mats were prefabricated to match the skew. A trackhoe was used to set the mats onto the deck where they were transported to the proper place on the deck using the work bridge which rolled on the finishing machine rails. Figure 1 shows an example of bridge deck replacement. 


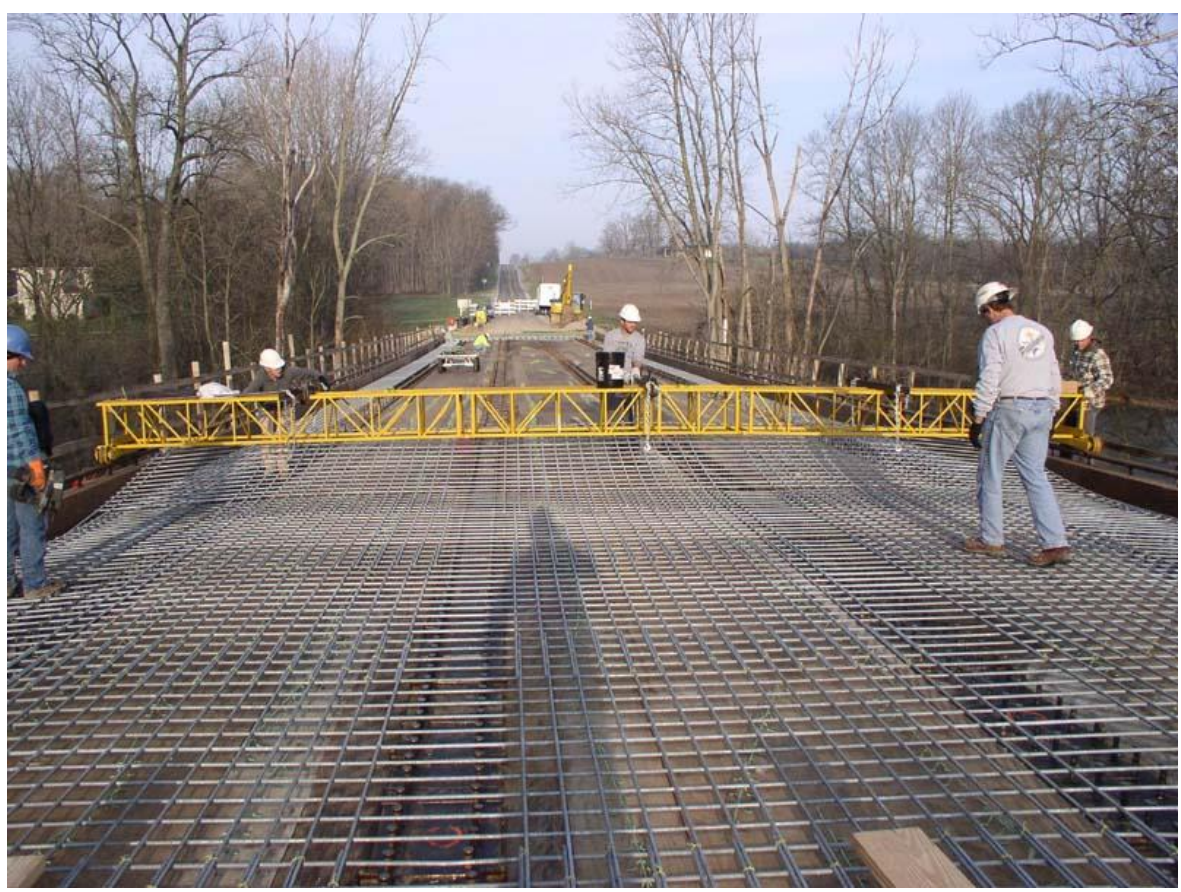

Figure 1 Bridge Deck Replacement with WWR

Figure 2 shows stacked welded wire on a construction site.

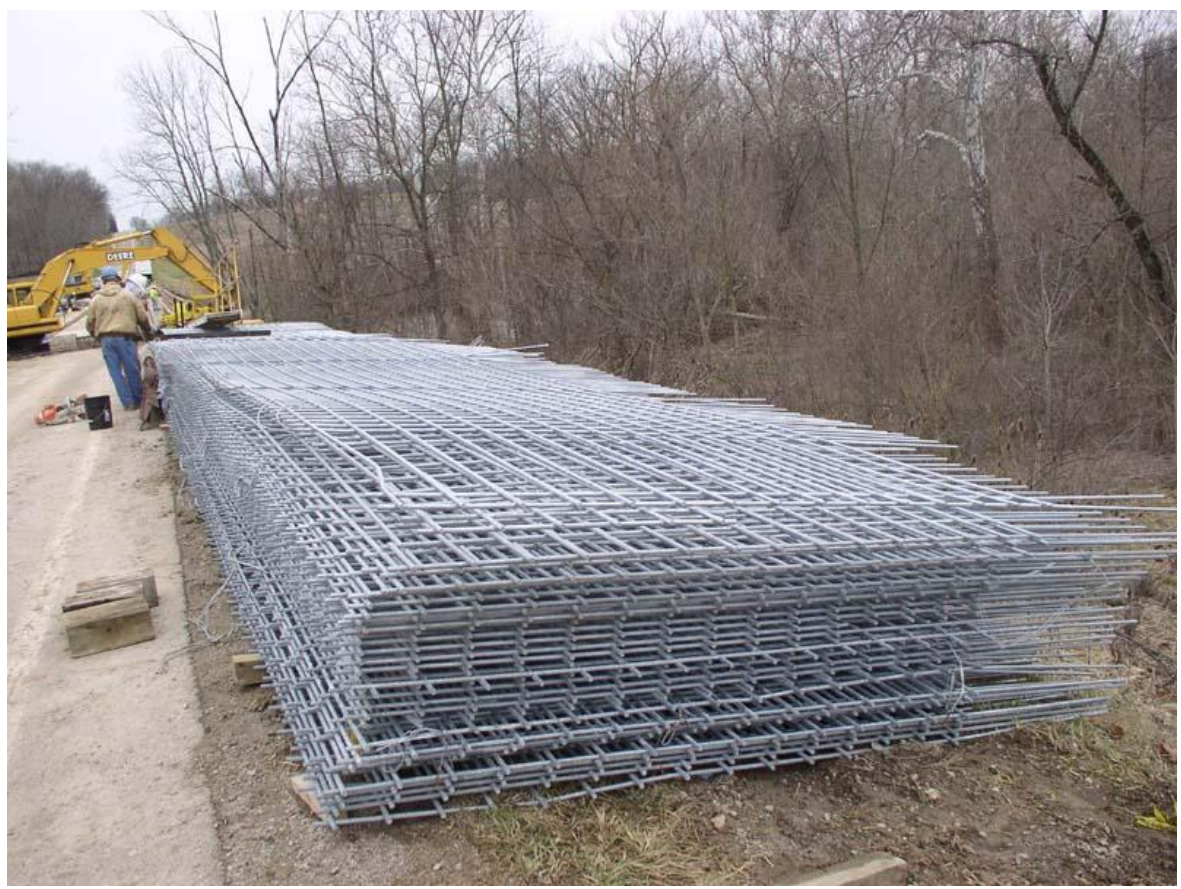

Figure 2 Stacked Welded Wire 
The deck design was based on four beams at 8 ' c/c and a nominal deck thickness of $8 \frac{1}{2}$ "'. Reinforcement consisted of two mats with $1 \frac{1}{2}$ ' bottom cover and $21 / 2$ " top cover. The top mat was comprised of D 20.8 wire @ 5" centers transversely and the bottom mat had D 19.6 wire @ 6" centers. The longitudinal wires were D19.6@ 5" spacing with additional D29 wires over the piers. The beams were also retrofitted with shear connectors to produce a composite deck. The bridge had a 3'-9" overhang on both sides and the railing consisted of a conventional concrete parapet.

ODOT chose the prefabricated wire mats for deck reinforcement on this project for several reasons. The primary reason was to speed up construction by eliminating the time it takes to place and tie individual rebars. By using the prefabricated mats, there was precise spacing and uniformity of the placement. Another advantage, not originally anticipated, was a much more rigid mat which did not move or deflect from the workers walking on it. ODOT is very interested in expanding the use of this method of reinforcing concrete. Even though not used on this project, the use of prefabricated wire mats for parapets also has considerable benefits. Figure 3 shows an example of welded wire installation.

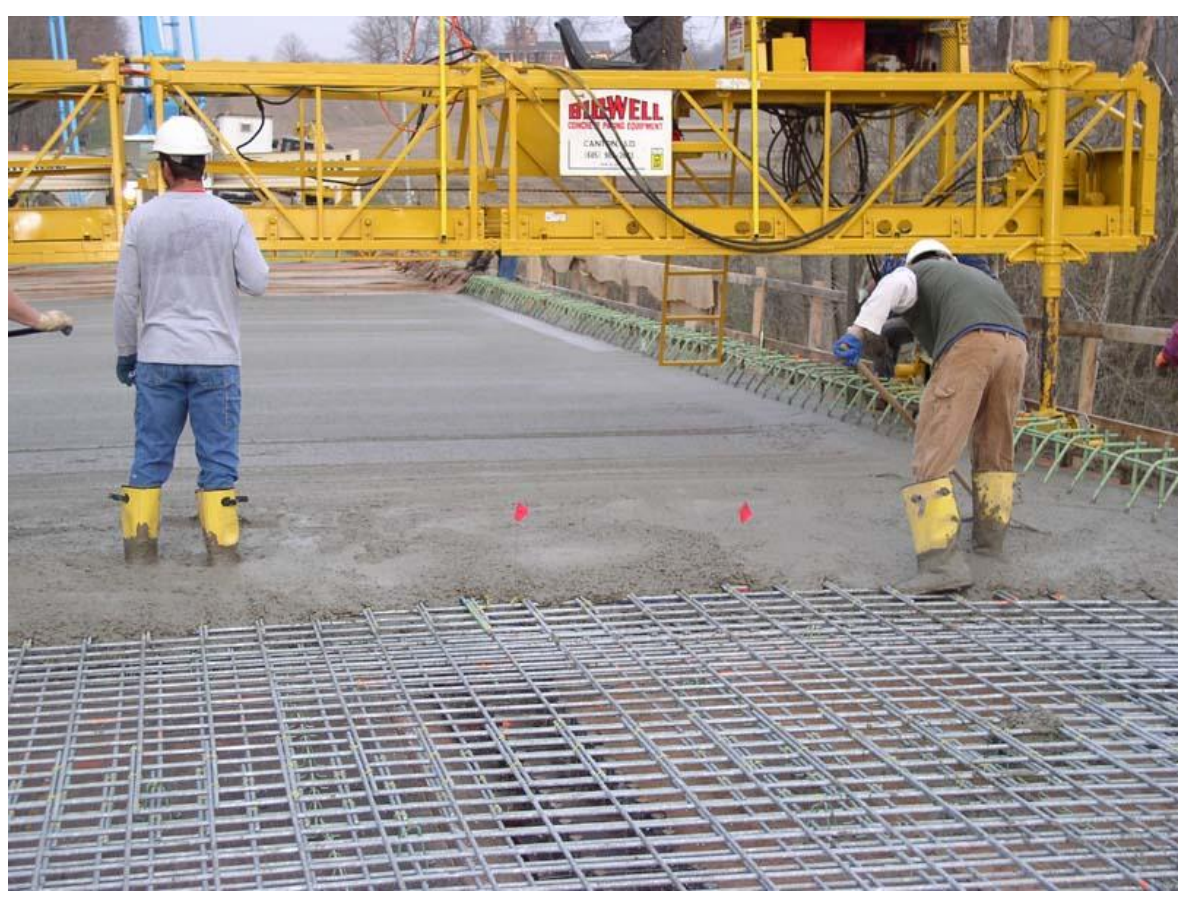

Figure 3 Welded Wire Installations 
Welded wire reinforcement has also been used in other transportation applications, such as:

- Barrier wall construction

- Box culverts

- Precast concrete beams

- Retaining walls

- Paved ditches

Current market prices for welded wire reinforcement (WWR) are epoxy coated at $\$ 0.37 / \mathrm{lb}$. and $\$ 0.19 /$ lb. for galvanized. The galvanized wire is very cost competitive with epoxy coated rebars. Adding in labor savings for WWR then bridge deck applications could be constructer cheaper and faster than those using rebar. Appendix G is a collection of WWR specifications that various state agencies use.

\section{$\underline{\text { Precast Modular Concrete Systems }}$}

The use of precast modular concrete systems (PMCS) is mainly limited to bridge and culvert construction. Most bridge construction entails placing a set of precast, prestressed concrete girders over a span and then constructing the deck on top. Construction projects involving bridges present special problems for state highway agencies and contractors. Often bridges are vital roadways and cannot be completely closed during the construction project because many times there is no feasible way to detour traffic. There have been instances where the entire bridge section was constructed nearby on site and then moved and set in place using cranes or crawlers.

There are several advantages to using a PMCS:

- Higher quality

- More design options

- Less disruptive to all of the stakeholders

- Improved safety

- Greater fire resistance 
The structure is built in a controlled environment. The precast structures tend to have a higher quality and less variation than the onsite built structure. The structure has more design options. Many times the road has to transverse deep canyons, large expanses of water or other obstacles either man-made or natural. Having the large parts of the structure built offsite relieves some of these pressures. There is no need to build the forms, pour the concrete and then wait 28 days for the concrete to fully cure. Since the structure is built off-site it is constructed on its own schedule, thus it taken out of the critical path of the project. The precast structures are built off site and then delivered, the time and disruption of traffic to set up the forms, pouring the concrete, curing, and form removal are not part of the schedule. There is less disruption to the traffic flow and environment. Also neighbors and the surrounding environment are less disrupted since the construction time line is shortened. In many cases several months are cut from the project schedule. Work site safety is improved because less time is involved for workers to be near traffic. Work on the off-site structure is not much affected by weather, which can be beneficial in the northern United States. Structures that are built onsite also tend to be over engineered to account for the unpredictable nature and quality of on-site construction. (FHWA, 2006)

Fire Resistance is much greater. Many state highway agencies are discovering that even after vehicular accidents with an immense fire, there is little or no damage to the precast structure. Since bridges are often crucial arteries, officials are often onsite as soon as the concrete cools to assess any damages. In almost all cases, there is no structural damage and the bridge is allowed to reopen (PCI, 2008).

In addition to precast girders, bridge decking can be delivered as either partial depth or full depth deck panels. If the deck panels are delivered on road, weight limits restrict the deck panels to a partial depth, whereas if the deck panel is delivered off road, then full depth deck panels may be brought in. If the deck panel is a partial depth, then the deck is finished onsite with poured concrete overlay.

If a structure is on a heavy use roadway, many state highway agencies are choosing to replace the entire superstructure system over the course of a weekend. The new structure is built nearby and when it is completed the existing structure is cut up and removed and the new structure is 
moved into place using cranes or crawlers, and the roadway is reopened by Monday morning. The placement of PMCS is often done during off-peak or nighttime construction because frequently with bridge rehabilitation, the bridge can only be shut down for a short period of time, and only during off - peak times.

Steel prices, until very recently, were fairly stable, and much lower than precast, pre-stressed concrete segments. However, in recent years, there have been several price increases in steel costs which make it much more difficult for estimators and contractors. Although concrete prices have also increased, they have not increased at the rate that has occurred with steel. According to Heinrich Bonstedt of the Precast/Prestressed Concrete Institute (PCI) in general the cost savings for using a precast concrete structure is about $20 \%$ on spans shorter than 35 feet. And in spans longer than 165 feet, the costs are equal or better in favor of precast concrete structures (personal communication, May 22, 2008). In areas near salt water, precast concrete structures must be chosen because of the corrosive environment.

\section{Accelerated Bridge Construction (ABC)}

Accelerated bridge construction $(\mathrm{ABC})$ is the process where the repairing or replacing a bridge or any of its elements is accomplished in a short period of time. Using traditional construction methods typically a bridge is out of service for several months. However with ABC the closure is reduced significantly. In extreme cases on vital roadways, the bridge is completely replaced over a weekend. This is done by using either prefabricated components or building the bridge nearby and moving it into place with either a crane or self propelled modular transporters (SPMT) shown in Figure 4. SPMTs are multi axle platform transporters which have the ability to move several hundred tons both vertically and horizontally.

The reasons for using $\mathrm{ABC}$ are obvious. Very rarely can a detour around a bridge take place, and in an urban setting, a section of road containing a bridge often has a higher amount of daily road users. There is one joint Kentucky/Indiana project labeled the Milton-Madison Bridge over the Ohio River which may merit further investigation. See

http://www.fhwa.dot.gov/bridge/accelerated/abclist.cfm for more details. 


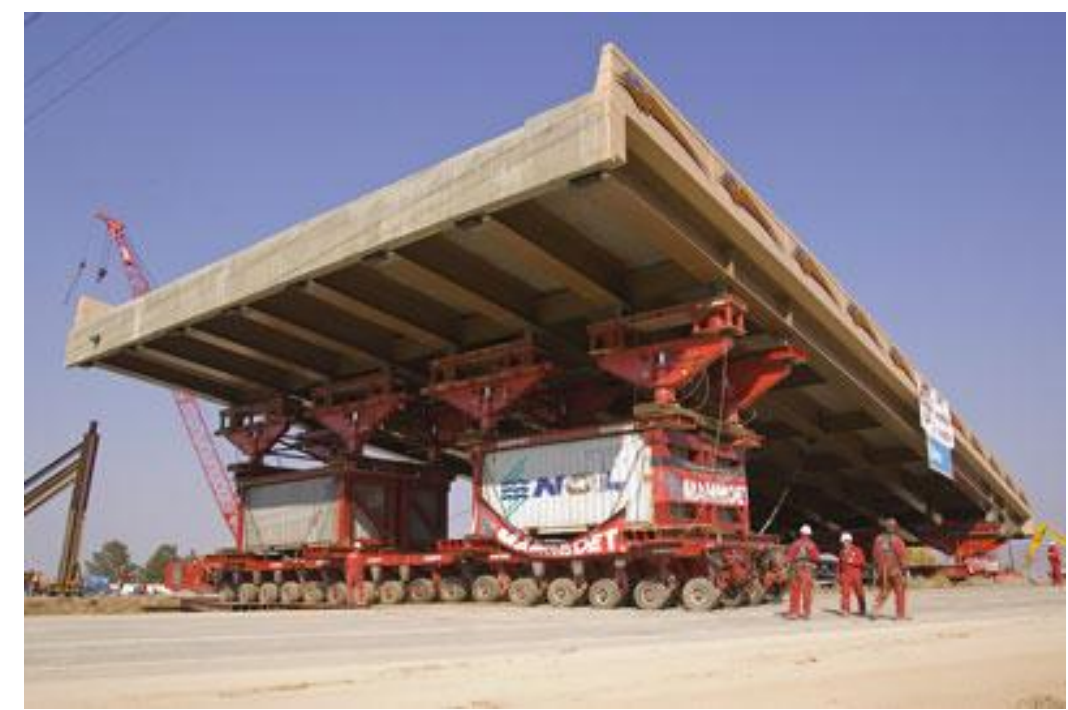

Figure 4 Self Propelled Modular Transporters (SPMT) (FHWA, 2007)

The benefits of an accelerated bridge construction project are numerous and include:

- Build elements offsite

- With available equipment, the elements can be installed rapidly.

- Decreased construction time.

- Impact to wildlife, neighboring residents is minimized.

- Bridge elements are built in a controlled environment resulting in higher quality.

- When daily road user cost is factored in, the cost savings can be substantial.

- Improvement in work zone safety (FHWA, 2005).

In the article "Framework for Prefabricated Bridge Elements and Systems (PBES) DecisionMaking (FHWA, 2005)", the authors note that not every bridge project needs to be accelerated. Some common questions that need to be addressed include:

- Does the project need to be fast tracked?

- What is the applicability of the design, will it allow itself to be built with prefabricated materials?

- What are the abilities of the contractors and suppliers?

- Is there access to the project site for deliveries of pre-cast elements?

- How will the construction requirements affect the cost and schedule? 
- Are the owners, contractors, and suppliers committed to an accelerated schedule?

- Is there a willingness to share responsibility, control, risk and resources?

- Do all parties understand the value of time?

Table 6 is a decision matrix for helping decide if a prefabricated bridge project is the correct path. Although the matrix is developed for prefabricated bridges, it can be used for any accelerated roadway project. The presentation by McMinimee also points out that there is a learning curve for innovative methods with any project. In the beginning, cost may be almost double when compared to traditional methods, but as contractors become more successful using an innovative method, costs eventually decrease until they are well below the cost for the traditional methods. Utah DOT, for instance, notes that in 15 projects using precast deck panels the overall cost per square foot has decreased from $\$ 70,000$, to under \$50,000. (McMinimee, 2008)

According to Daniel Snell of the Utah DOT the current cost to replace a bridge is not that expensive. In October 2007 they replaced a bridge using SPMT for \$7.7 million. Of that \$3.7 million went directly to construction costs and $\$ 4$ million was for the design costs. The bridge was located at 4500 South over I-125 in Salt Lake City. Traffic on I-125 was detoured starting at 9:00 PM on Friday evening and resumed at 3:00 AM Monday morning. The dimensions of the bridge are $175 \mathrm{ft}$ long and $45 \mathrm{ft}$ wide with three spans including two main lanes, one turning lane, and shoulders. Utah DOT officials have made it a goal to put every bridge replacement or reconstruction on an accelerated time schedule. 
Table 6 Matrix Questions for a Prefabricated Bridge (FHWA, 2005)

Question

1. Does the bridge have high average daily traffic (ADT) or average daily truck traffic (ADTT), or is it over an existing high-traffic-volume highway?

2. Is this project an emergency bridge replacement?

3. Is the bridge on an emergency evacuation route or over a railroad or navigable waterway?

4. Will the bridge construction impact traffic in terms of requiring lane closures or detours?

5. Will the bridge construction impact the critical path of the total project?

6. Can the bridge be closed during off-peak traffic periods, e.g., nights and weekends?

7. Is rapid recovery from natural/manmade hazards or rapid completion of future planned repair/replacement needed for this bridge?

8. Is the bridge location subject to construction time restrictions due to adverse economic impact?

9. Does the local weather limit the time of year when cast-in-place construction is practical?

10. Do worker safety concerns at the site limit conventional methods, e.g., adjacent power lines or over water?

11. Is the site in an environmentally sensitive area requiring minimum disruption (e.g., wetlands, air quality, and noise)?

12. Are there natural or endangered species at the bridge site that necessitate short construction time windows or suspension of work for a significant time period , e.g., fish passage or peregrine falcon nesting?

13. If the bridge is on or eligible for the National Register of Historic Places, is prefabrication feasible for replacement/rehabilitation per the Memorandum of Agreement?

14. Can this bridge be designed with multiple similar spans?

15. Does the location of the bridge site create problems for delivery of ready-mix concrete?

16. Will the traffic control plan change significantly through the course of the project due to development, local expansion, or other projects in the area?

17. Are delay-related user costs a concern to the agency?

18. Can innovative contracting strategies to achieve accelerated construction be included in the contract documents?

19. Can the owner agency provide the necessary staffing to effectively administer the project?

20. Can the bridge be grouped with other bridges for economy of scale?

21. Will the design be used on a broader scale in a geographic area? 
Precast/Prestressed Concrete Institute (2006) lists several components which can be used to accelerate the construction of a bridge. These include but are not limited to:

- Precast Elements

- Pier footings, columns, and caps

○ Deck slabs

- Girders and Box beams

○ Piles and pile caps

- Railings and other architectural elements

- Prefabricated sections

$\circ$ Walls and wall segments

○ Deck slab segments

- The entire superstructure

The report also gives three in-depth case studies of projects in the northeast United States where accelerated bridge projects were done.

In the United States, the term accelerated bridge construction usually means the complete construction or replacement of the bridge, but in other parts of the world, this term may refer to any of the multiple activities that take place in the construction of a bridge. In the summer of 2002 a group of geotechnical and structural engineers from FHWA, various state highway agencies (SHA), academia, and the private sector toured several countries in Western Europe, where they met with several European engineers to identify and share alternative methods or techniques to accelerate the bridge construction process. As documented in "Innovative Technology for accelerated Construction of Bridge and Embankment Foundations of Europe" (Dumas et. al., 2003), the technical report published by the American Trade Initiatives and sponsored by the USDOT-FHWA the group recognized 15 processes currently used in Europe which would prove promising in the United States. Many of these methods and materials offer a prospective in cost savings, and/or advancements in quality over current systems. Some of these items include:

- Column-supported embankments

- Continuous flight auger and cased secant pile bridge foundations

- Automated computer installation control and installation documentation 
- Extensive and innovative use of Self Compacting Concrete (SCC)

- Embankment mat foundation systems and equipment

- Innovating earth-retention systems

- Embankment deep foundation systems

- Extensive requirement of QC/QA programs such as ISO 9000 series

The first four items listed were tabbed for immediate implementation in the U.S. Many European countries stress that roadways remain open, noise be kept to a minimum, and good public relations maintained.

The cost for accelerating a bridge construction depends upon two main factors. They are the DRUC (Daily Road User Cost) and the ability and familiarity of all parties involved. The most important of which is the DRUC. If the road usage is high enough, then the cost savings of accelerating the construction project is well worth the cost. As noted by Heinrich O. Bonstedt of PCI, precast girders on shorter spans ( $<35 \mathrm{ft}$.) there is approximately a $20 \%$ initial cost savings over steel. For a longer length up to 165 feet, the cost savings reduce down to zero (personal communication, May 22, 2008). Precast elements and prefabricated sections can offer comparable costs to cast-in-place especially when other factors such as being unable to close the section of road for several months at a time.

If there are other factors which need to be addressed such as environmental issues or worker safety which can be helped by greatly reducing the construction time, then maybe the cost of accelerating the bridge construction can be justified.

\section{$\underline{\text { Innovative Contracting Methods }}$}

In previous sections the focus was upon materials. These next two sections will focus upon scheduling and different contracting methods.

Since 1990, the FHWA has allowed State DOTs to evaluate non-traditional contracting techniques under a program titled "Special Experimental Project No. 14 - Innovative Contracting." Originally, the contracting practices approved for evaluation were: cost-plus-time 
bidding, lane rental, design-build contracting, and warranty clauses. After a period of evaluation, the FHWA decided that all four practices were suitable for use as operational practices, that is, they were no longer deemed experimental. Thus in 2002, the title of SEP-14 was changed from "Innovative Contracting" to "Alternative Contracting." (FHWA, 2005)

By introducing different ways of forming a contract, the whole mindset must be changed. Innovative contract methods are intended to motivate the contractor to manage the whole system better by working faster, more creatively, reducing float, and scheduling accurately. There are several options which do not result in an increase in overall costs, or if there is an increase, it is very minimal. These options include:

- Bidding on cost/time $(\mathrm{A}+\mathrm{B})$

- Incentive/disincentive (I/D)

- Bidding cost/time $(\mathrm{A}+\mathrm{B})$ combined with incentive/disincentive (I/D)

- Lane rental

- Design-build

Each of these methods includes the cost of time as a factor. In other words, what is it worth to the state or owner to have the contractor reduce the project time period? It includes the costs of a delay or speed up of the project. Because each road or section of highway is different, many state highway agencies have developed their own system for incorporating the time factors.

Bidding on cost/time, or $\mathrm{A}+\mathrm{B}$ bidding is a well known idea even though it is relatively new in the United States. The ' $A$ ' refers to the actual cost of the project and the ' $B$ ' refers to the duration of the project where a daily road user cost is calculated by the SHA engineers. Contractors are required to submit a bid with two sections. The intention is to encourage contractors to work more efficiently and to adopt alternative or innovative and aggressive scheduling to reduce the construction duration and inconvenience to the road users (Kent, 2008). Many SHA feared that this may force contractors to use sub-par materials or perform sub-par workmanship, so it was common to require a third element ' $C$ ', which is a five year warranty, thus it was often referred to as ' $\mathrm{A}+\mathrm{B}+\mathrm{C}$ Bidding'. Today it is common to require all contractors 
to give a five year warranty for all highway roadwork. The project team is to find out the Indiana Department of Transportation (INDOT) used to require this in A+B projects in the past.

Incentive/disincentive (I/D) is perhaps the most commonly recognized type of contracting method designed to decrease the project construction time. The state highway agency posts incentives for completing a project early and disincentives or fines for completing a project late. The dates set generally are ultimate dates and have a "No Excuse Clause" associated with it. Usually these incentives are based upon the DRUC although some state highway agencies set I/D as a percentage of the total construction cost. Many state highway agencies set the fines and incentives equal to one another. Some states have had more response when vary the amounts if the project has special conditions. Ordinarily the maximum amount that the contractor can earn or lose varies among states, either a percentage of the total construction costs, a set dollar amount depending upon the project. Indiana Department of Transportation (INDOT) sets the incentive/disincentive to a specific dollar amount per project.

Bidding on A $+\mathrm{B}$ with $\mathrm{I} / \mathrm{D}$ is a combination of these two methods and is easy to understand. Contractors bid on the construction project using the bidding on cost/time and if they complete the project early or late they receive a bonus or fine. This method has proven to effectively reduce the time that contractors have included in their original bid.

Lane rental is a new technique which was first introduced here in the United States from Great Britain in 1990 where it is used to a great extent. The idea behind this technique is to encourage the contractor to keep the traffic moving and minimize the disruption to the motorists. The state highway agency sets the construction period and determines the cost of closing a lane during different periods of the day and week. This rate may be set in units of days or hours but includes the cost of the disruption to the motoring public. Each contractor bidding on the project submits a bid which includes the estimate of the work along with the amount of time and when the lane closures are to be used. Closing more than one lane may have escalating rental fees for each additional lane. The total cost is the sum of the work to be performed plus the costs of the lane closures. Contractors will then have to manage the construction process better, schedule deliveries, and work more precisely. This is one technique where, if the contractor spends a little 
more time in the planning stage, he will be better prepared. The largest caveat of this method is related to deliveries. Since so many deliveries are dependent upon traffic flow, scheduling deliveries under this method is rather difficult because of the lack of float. This practice does require more state highway agency inspectors and engineers to be on-site because the contractors schedule is much tighter, but this increase in engineers' wages is offset by the savings to the state. INDOT has used this technique on several projects with favorable results.

Design-Build is a method where the state highway agency lets the contractor figure out how to best design and build the structure according to their expertise or strengths. The state highway agency sends out an RFP in the initial phase to a list of contractors from a qualified list. The contractors wishing to respond submit their proposals with only the technical approach and their experience. The state highway agency then chooses a short list of contractors and asks for a detailed proposal containing the design, build and carry out this proposal. The biggest benefit from this technique is that it allows work to begin before the final design has been accepted. The best examples of this are emergency work such as an accident involving a bridge or a reconstruction of a major road that has become impassible due to an act of God. If the state highway agency does not have the as-built drawings from the previous construction, or if the roadway needs updating, this might be the quickest route to completion. In this instance, with a list of the contractors in hand a state engineer can call all of them and ask them to come to where the problem is. Usually within 24 hours the initial proposals have been received, and the state officials are narrowing the list. As one can see, this method relies heavily upon the expertise of the contractors.

All of these contracting methods compare the state highway engineer's estimates on project time under the current common practices. By comparing this with the contractor's estimate for the time to complete the project, the contractor can be successful. The state highway agency must practice diligence to be certain that its engineer's time frames are not overly generous. If their numbers are inflated, then it would be easy for a contractor to just be diligent in order to be successful. If, on the other hand, a contractor that is behind may attempt to catch up by 'cutting corners', the state must make sure it has enough engineers and inspectors on-site to see that this does not happen and that work is flowing according to the schedule. Overall state highway 
agencies have seen a decrease of between 20 and $50 \%$ in the time that contractors take to complete the project. (Herbsman, 1995)

\section{Off-Peak/Nighttime Construction}

As society moves towards the acceptance of working around the clock, many contractors are looking at this option to reduce project time and increase productivity. State highway agencies are looking at scheduling work during off-peak or during the nighttime to relieve congestion on the roadways. Whether or not it is beneficial, for a construction project to work outside the peak work time is something that the schedulers and planners must decide. Sometimes it is less costly for all of the stakeholders involved to schedule work during the day, other times it is in the best interest to work during the night, occasionally it is a combination of both. The lane rental technique listed above might fall into this category. Since our highway traffic patterns have peak and off-peak times, it may be a better choice to schedule work that has to be done during offpeak times. State highway agencies need to first find out what the average traffic is for the construction zone for the different time periods. Usually peak periods are between 8 am and 6 pm, shoulder periods are the three hours prior to and after this (5-8am and 6-9 pm) and nighttime and weekends encompass everything else. Table 7 shows usual peak periods.

Table 7 Usual peak periods

\begin{tabular}{|c|c|c|c|c|}
\hline & time period & peak & shoulder & off peak \\
\hline Mon-Fri & $12 \mathrm{am}-5 \mathrm{am}$ & & & $\mathrm{X}$ \\
\hline & $5 \mathrm{am}-8 \mathrm{am}$ & & $\mathrm{X}$ & \\
\hline & $8 \mathrm{am}-6 \mathrm{pm}$ & $\mathrm{X}$ & & \\
\hline & $6 \mathrm{pm}-9 \mathrm{pm}$ & & $\mathrm{X}$ & \\
\hline & $9 \mathrm{pm}-12 \mathrm{am}$ & & & $\mathrm{X}$ \\
\hline \multicolumn{2}{|c|}{ weekends } & & & $\mathrm{X}$ \\
\hline
\end{tabular}


Although it may sound like a good option to schedule work during the off-peak hours, several factors must first be weighed. The various factors that affect the decision to work during the off peak hours include:

- Traffic

- Construction

- Social

- Economic

- Environmental

- Legal

While safety is a much larger concern during nighttime work, the number of accidents is less during the night because of lesser amount of traffic. All contractors, employees, engineers and designers should attend a nighttime safety class prior to beginning work. Given the time of the day, driver and worker impairment is more likely, so the addition of traffic control measures such as additional signage and increased patrols by local and state police are needed. The alternate traffic routes around the construction project need also to be considered. Most side streets around a construction project see a major increase in traffic as motorists try to avoid the delays associated with the construction. The wear and tear of these streets can lead to premature failure if these streets are not rated for the increase in volume and heaver weight placed on them by the additional cars and trucks. Scheduling the work at night will help the congestion of these side streets.

Because there is less light during the nighttime, the quality in the work has to be assured that it does not suffer. Engineers and other technical experts should be available if questions should arise, and at night this may be difficult. Productivity as a general rule will increase because of the less traffic and longer work shifts. However, if traffic controls (signage) and lane closures are temporary, this longer shift may be offset by the daily setup and takedown of these controls. The cooler temperatures at night also facilitate in other ways. They will help the workers perform better if the average daytime temperatures are excessive. In addition, it is not recommended that concrete be poured if the temperature is projected to be above $90^{\circ} \mathrm{F}$, so the 
quality of concrete poured and finished will be improved if it is done at night when the temperatures are cooler.

Retraining the human body to working at night is sometimes difficult and can take months. Until that happens, workers run the risk of worksite accidents and a general lack of quality from a minimal amount of sleep. Neighbors also probably do not want to have a construction crew nearby working at night if they are trying to sleep. The wide-ranging sights, sounds and vibrations of a construction crew such as slamming tailgates, backup alarms, heavy equipment running, vibratory rollers, additional dust, and the addition of portable lighting, will make it very difficult for people nearby to sleep or enjoy their evenings. Because of this, good public relations for the contractor and the state highway agency are probably the most important factor of all that are considered.

There are a wide variety of economic costs both negative and positive associated with nighttime construction. Overtime pay or a shift differential can escalate the cost of the project by as much as $50 \%$. The indirect factors include lighting and noise muffling equipment if the job is an urban setting, as well an increase in costs associated with additional signage and patrolling by local law enforcement. User costs, or those costs connected to the cost to drive from point A to point B will be lower during this time period because there is less traffic on the road. Also, the user cost during peak times will also be lower because there is little, if any, construction taking place during this time. In addition, if there are businesses which will be affected by the construction project, working at night would be beneficial for them. Accident costs are another economic cost coupled with nighttime construction. As one can correctly assume, the probability of an accident happening is much greater, but there are less motorists on the road to offset this factor. However, accidents do tend to be more severe. During the day as a rule accidents in construction zones tend to be minor or 'fender-benders', but at night roads are less congested and drivers tend to have some amount of fatigue.

The two largest environmental factors benefiting from an off-peak or nighttime construction are air quality and fuel consumption. Since there is less traffic, and less congestion around the construction site, the traffic that is passing through has shorter delays or stops, fuel economy is 
better and there is less air pollution. This factor is especially appealing to areas located in valleys which have a stagnate air mass and larger amounts of smog.

Many communities have noise ordinances limiting the decibel level allowed at night. Since people living close by cannot move, the nighttime work scheduled with the project will have the most effect upon them. They may voice their opinions and feeling to the local government which may change the schedule radically if the disruption to the neighbors is too great.

All of these factors and their weights vary with each construction project. Many communities have hearings where the idea of scheduling a project to be done at night must be aired and approved before the bid process can even be started. It has been shown that the contractor's familiarity with nighttime construction is important to the overall construction process.

\section{Highways for Life}

Recently the FHWA announced a new program titled "Highways for Life", or HfL. The goal of this program is to search domestically and internationally for new and innovative methods for the construction of our highway system. In fact the HfL mission statement is as follows:

"The purpose of Highways for LIFE is to advance Long lasting highways using Innovative technologies and practices to accomplish Fast construction of Efficient and safe pavements and bridges, with the overall goal of Improving the Driving Experience for America." (FHWA, 2008)

Their unofficial motto is to build roads "better, faster, safer and cheaper". The Safe, Accountable, Flexible, Efficient Transportation Equity Act: A Legacy for Users (SAFETEA-LU) has given the Highways for Life program \$75,000,000 total for fiscal years 2006-2009 to give to states for highway projects that incorporate a new approach to highway construction. Any transportation department may apply for some of this funding if the project constructs, reconstructs, or rehabilitates a roadway that is eligible for federal highway funds. The project must use innovative techniques or materials that meet the four criteria:

(1) Improve Safety 
(2) Congestion Relief caused by Construction

(3) Improve Quality

(4) Improve User Satisfaction

The amount of money that SAFETEA-LU will give is up to $20 \%$ of the total cost of the project, but not more than $\$ 1,000,000$. The goal is to help fund at least one project in every state. The remaining balance of funding for the project is still eligible for federal highway funds.

SAFETEA-LU officials ask that state highway agency exercise restraint in applying since the goal as stated isn't to fund every project, but to help state highway agency look at alternative ways to accelerate the construction process. To date only 15 states have received funds from the HfL program.

Although many believe that HfL may encourage state agencies to apply innovative technologies to accomplish fast, safe, efficient, quality construction, INDOT does not have any plan on this in the near future. It is mainly because of the lack of matching fund required by FHWA. 


\section{A+B Contracting by INDOT}

The following items were investigated to the use of $\mathrm{A}+\mathrm{B}$ contracting.

- Previous projects in the state of Indiana

- Previous projects in other states

- Lessons learned

- Reasons for discontinuation in the state of Indiana

- What it takes to resume $\mathrm{A}+\mathrm{B}$

Previous projects in the state of Indiana

The first use of A+B Bidding was a major rehabilitation project on I-70 east of Indianapolis which was completed in 1996. Its completion was reported to FHWA for the TRB's files. See http://www.tfhrc.gov/focus/archives/106inabc.htm for details. INDOT set each peak-period lane closure at $\$ 13,800$, each non-peak-period lane closure at $\$ 4,600$, and each contract day at $\$ 2,000$. Milestone Construction Co. was the contractor performing the work. To ensure early successes, INDOT formed a user-producer group to identify all of the specifications, so everyone would know what is expected. Another group of INDOT officials, contractors, subcontractors and suppliers met often to guarantee success by assuring proper communication and cooperation.

This first project was successful, and INDOT let seven more projects on 1996 and approximately 10-12 projects in 1997 based on either $\mathrm{A}+\mathrm{B}+\mathrm{C}$ or $\mathrm{A}+\mathrm{B}$ bidding. Beyond that it is not known how many years INDOT used this contracting method before they abandoned it.

\section{Previous projects in other states}

Many SHA have adopted this alternative contracting method with generally good results. It appears that there are almost 40 states that are active users of this method (Carpenter, 2003), although this number may have changed. Most report favorable results, although some report 
caveats of this method. These caveats seem to be common and expected and appear to be related to a SHA learning curve.

\section{$\underline{\text { Lessons Learned }}$}

Kent (2008) has identified the following characteristics associated with successful A + B bidding projects:

- High traffic volume areas (urban)

- Projects that will complete a gap in a significant highway system

- Major reconstruction or rehabilitation on an existing facility that may severely disrupt traffic

- Major bridge out of service

- Major projects with lengthy detours of high volumes of traffic

- Projects in high accident locations

- Projects with a preconstruction level of D or worse

- Areas that may have an important event approaching

Advantages of $\mathrm{A}+\mathrm{B}$ bidding include:

- Encourages contractors, subcontractors, suppliers and state officials to be well prepared and more efficient.

- Encourages contractors to schedule arrival of materials and work crews to maximize the operation.

- Promotes overtime, off-peak and nighttime scheduling.

- Road User Costs are reduced.

- Encourages alternative and innovative ways for contractors to reduce project duration.

- Pollution is reduced.

Disadvantages include:

- An increased burden on local resources including manpower. This includes state officials and inspectors which must be available when the crews are working. Smaller contractors 
may not have access to the resources to expedite the projects. Those contractors who are not well prepared may find themselves behind.

- Quality, if not watched closely can deteriorate.

- In some instances, there is an increase in direct, obvious project costs. This may affect other projects.

- Time becomes the main driver, not quality.

- Learning curve can be cumbersome. (Thompson, 2008)

It should be noted that $\mathrm{A}+\mathrm{B}$ bidding is not for every project. Road User Costs must be significant enough to entice contractors to want to bid on the project. Many times an Incentive/Disincentive is coupled with $\mathrm{A}+\mathrm{B}$ bidding. But there must be a cap on the amount of incentives for fiscal and budgeting reasons. Kent points out that "The maximum number of days of incentive for each incentive period is limited to $10 \%$ of the number of days estimated by the engineer rounded to the nearest whole day. In addition, the sum of all incentives for a single contract is limited to 5\% of the engineer's estimated contract amount." Keep in mind that contractors must have a lower ' $\mathrm{B}$ ' to be the lowest bidder.

Kent (2008) presents some impressive findings from NYSDOT. Of 120 projects totaling $\$ 2.0$ billion completed using the $\mathrm{A}+\mathrm{B}$ bidding:

- On average, contractors bid 32\% less than the department's estimated time and completed ahead of schedule.

- $75 \%$ of these contracts were awarded to the lowest ' $A$ ' bidder. That is to say, the contractor, who had the lowest overall bid, also had the lowest ' $A$ ' portion of the bid. Of the remaining $25 \%$ the contract winners were within $1 \%$ of the lowest 'A' bid.

- $86 \%$ of the contractors earned incentives (NYSDOT also has an Incentive/disincentive system attached the $\mathrm{A}+\mathrm{B}$ bid). Total incentives were approximately $2.5 \%$ of the total cost of the projects. $7 \%$ of the contractors were fined for not completing on time. Total cost of fines is less than $\$ 600,000$.

- $50 \%$ of the contractors asked and received adjustments to the ' $\mathrm{B}$ ' portion of the contract because of circumstances outside of their control. 
- Estimated cost saving was $\$ 246$ million.

- Estimated construction time saved was 20,000 days.

\section{$\underline{\text { Reasons for discontinuation in the state of Indiana }}$}

It is not immediately known why INDOT has discontinued this method. It is surmised that A + $\mathrm{B}$ bidding is best used in urban areas where time is a critical factor. Since Indiana has only a few areas that meet this requirement such as Indianapolis, Louisville, Cincinnati, and NW Indiana, it does not seem as applicable around other parts of the state. Thus, in other areas that might consider this optional method, careful planning and timing of projects by state officials might make this method unimportant. Opposition or lack of education by contractors might also hinder this method.

In order to find out more on $\mathrm{A}+\mathrm{B}$, the project team interviewed Greg Kicinski on the phone on August 18, 2008. Kicinski is currently in charge of all design-build projects for INDOT. He provided some background of INDOT's A+B practices in the past.

Answering the question as to why INDOT does not use A+B contracting, he replied that it is not so much as INDOT not using $\mathrm{A}+\mathrm{B}$ contracting as INDOT has not used this in probably the last five years. The last project that he can remember using A+B contracting was I-465 in Indianapolis on the east side near Shadeland Ave. exit (Fall Creek area). At the time he was a project engineer in the field.

Then why has INDOT not used A+B contracting? There are probably two reasons for that:

1. A lack of understanding by those who are in charge of setting up the contracts

2. The people in charge of setting up the contracts have left (either retired or moved).

Kicinski is a big proponent of $\mathrm{A}+\mathrm{B}$ contracting and has suggested in the past that a couple of projects be set up as $\mathrm{A}+\mathrm{B}$. He also is looking at setting up a project or two in the next year or so as an $A+B$ contract. Kicinski has seen $A+B$ flourish and has seen ramps, for instance, which 
were scheduled to be closed for 20 days be closed for 6 hours, 10 days reduced to no closure, all by setting up an alternative schedule.

\section{What it takes to resume $\mathrm{A}+\mathrm{B}$}

Since contractors are already familiar with the Incentive/Disincentive in Indiana, some education by both the state engineers and contractor's estimators is needed. State engineers need to study the site and thereby ensure that the project is completed on time or before the planned completion date. The engineers need to help the contractors achieve early completion. It may be helpful to make critical phases of a project subject to $\mathrm{A}+\mathrm{B}$ bidding.

Thus, as far as the study on the $\mathrm{A}+\mathrm{B}$ contracting, next step would include the following tasks:

- Contact contractors/project managers that were involved $\mathrm{A}+\mathrm{B}$ in the past.

- Collect and review any project reports from those projects that were done with $\mathrm{A}+\mathrm{B}$ contracting.

- Identify any critical problems with $\mathrm{A}+\mathrm{B}$ contracting.

- What projects from the Major Moves can apply A+B contracting.

A previous JTRP Synthesis Study “Innovative Contracting Techniques” produced a report in March 2007. A proposed Fast Track project "Exploration of Innovative Contracting Methods" will be performed starting in January 2009. The outcome will provide Project Managers with a decision tool and methodology on innovative contract options. The deliverable will be the completed Contracting Methods Manual. Implementation will be to incorporate the manual into the PDP, Project Development Process. The manual will be one of the resources referenced in this process. The benefit of performing the study is that it will provide INDOT project managers with resources to make this decision in the PDP, which currently is lacking. 


\section{Indiana Major Moves}

In order to identify major activities in INDOT transportation construction, Indiana Major Moves were studied in depth. Currently, INDOT classifies a little over $\$ 8.8$ billion projects as major transportation projects from 2006 until 2015.

Based on the INDOT project data provided by Mark Miller, it is figured that the Indiana Major Moves include the following major project types.

- New lanes construction

- New bridge construction

- New interchange (or intersection) construction

- New median construction

- Lane rebuild (replacement or major preservation)

- Additional lanes construction

- Interchange (or intersection) reconstruction (or improvement)

- Bridge replacement (or improvement)

- Pavement resurfacing

- Pavement rehabilitation (or repair)

- Drainage rehabilitation

- Nighttime reconstruction

- Preventive (or routine) maintenance (or rehabilitation)

Of all types of Major Moves projects listed above, the following four significant project types were selected for this study and some other sub-types nested within. The sub-types are listed under each major project as shown below. Nighttime reconstruction and preventive maintenance are not included.

- Lanes construction and pavement

- New lane construction

- Lane rebuild

- Pavement repair 
- Pavement resurface

- Bridge construction and replacement

- New bridge construction

- Bridge replacement or improvement

- Bridge resurfacing

- Interchange construction

- New interchange (or intersection) construction

- Interchange reconstruction

- Drainage rehabilitation

\section{Techniques to Accelerate Construction}

Now, in order to study techniques for accelerating construction at the activity level, the major activities of each project were found. This process is to investigate what activities (or procedures) can be expedited using advanced construction techniques available such as better materials or operations. There are currently two different categories of techniques available to speed up construction: engineering and management. The following lists show different approaches in each category below.

- $\quad$ Engineering
- PCCP with Admixtures
- Rapid Setting Concrete
- Asphalt Concrete Options
- Roller Compacted Concrete
- Precast Modular Concrete
- Welded Wire Reinforcement

- Management

- Innovative Contract Methods (e.g. A+B contracting)

- Off-Peak/Nighttime Construction

- Highways for Life 
Major Activities in Indiana Major Moves

With Major Moves and techniques for accelerating construction mentioned above, the following table shows major activities and corresponding techniques to expedite the practice. As one can notice, there are not many choices available on the engineering side to accelerate construction process other than improving materials or pre-casting. Also, notice that some activities cannot be expedited even by using any advanced techniques listed above. Acceleration on the management side ( $\mathrm{A}+\mathrm{B}$ contracting, nighttime construction, and Highways for Life) will be discussed later in this report. Table 8 shows typical activities and accelerating techniques that may replace existing activities in the Indiana Major Moves.

Table 8 Indiana Major Moves

\begin{tabular}{|c|c|c|}
\hline Project Type & Activities & Accelerating techniques \\
\hline \multirow{7}{*}{$\begin{array}{l}\text { Lanes construction } \\
\text { and pavement }\end{array}$} & Asphalt milling & N/A \\
\hline & Transition milling & N/A \\
\hline & HMA surface & N/A \\
\hline & HMA intermediate & N/A \\
\hline & HMA base & Roller Compacted Concrete \\
\hline & PCCP & Concrete Admixture \\
\hline & Concrete barrier & Roller Compacted Concrete \\
\hline \multirow{10}{*}{$\begin{array}{l}\text { Bridge construction } \\
\text { and replacement }\end{array}$} & $\mathrm{RC}$ bridge approach & Concrete Admixture \\
\hline & Concrete superstructure & Concrete Admixture \\
\hline & Concrete substructure & Concrete Admixture \\
\hline & Concrete & Concrete Admixture \\
\hline & Rebar & Welded wire reinforcement \\
\hline & Epoxy coated rebar & N/A \\
\hline & Epoxy coated threaded rod & N/A \\
\hline & RC moment slab & Precasting \\
\hline & Concrete railing & Roller Compacted Concrete \\
\hline & Concrete bulb-T beam & Precasting \\
\hline
\end{tabular}


Table 8 Indiana Major Moves (Continued)

\begin{tabular}{|c|c|c|}
\hline \multirow{18}{*}{$\begin{array}{l}\text { Interchange } \\
\text { construction }\end{array}$} & HMA patching & N/A \\
\hline & Widening with HMA & N/A \\
\hline & Milling asphalt $35 \mathrm{~mm}$ & N/A \\
\hline & Milling PCCP & N/A \\
\hline & Milling scarification & N/A \\
\hline & Milling transition & N/A \\
\hline & Milling approach & N/A \\
\hline & HMA surface & N/A \\
\hline & HMA intermediate & N/A \\
\hline & HMA base & Roller Compacted Concrete \\
\hline & PCCP & Concrete Admixture \\
\hline & PCCP patching full depth & Concrete Admixture \\
\hline & Concrete barrier & Roller Compacted Concrete \\
\hline & HMA for approaches & N/A \\
\hline & PCCP for approaches & Concrete Admixture \\
\hline & Concrete & Concrete Admixture \\
\hline & Epoxy coated rebar & N/A \\
\hline & Rout/seal cracks in PCCP & N/A \\
\hline \multirow{4}{*}{$\begin{array}{l}\text { Drainage } \\
\text { rehabilitation }\end{array}$} & Precast culvert $6 \times 4$ & N/A \\
\hline & Precast culvert $3 \times 2$ & N/A \\
\hline & Precast culvert $9 \times 3$ & N/A \\
\hline & Wingwall & N/A \\
\hline
\end{tabular}

Note: Rapid setting concrete can also be used where concrete admixture is applicable. 


\section{Survey INDOT Construction Managers}

Although there were a lot of efforts made by the project team and the SAC, there was no significant amount of responses from INDOT contractors and engineers. So, the project team was not able to take any benefits from project managers/engineers' input. See the Appendix B for the question asked in the survey. 


\section{Survey Other State Transportation Agencies}

There were 17 responses (26\% return rate) out of 65 survey recipients. States that responded are:

- Michigan

- Texas (2 responses)

- Montana (2 responses)

- Florida

- Idaho

- Kansas

- Louisiana

- West Virginia

- Colorado

- Pennsylvania

- Ontario, Canada

- Maine

- Arkansas

- Vermont

- Alaska

Below are the responses from 17 state agencies for questions 1 through 6. See Appendix $\mathrm{C}$ for the complete questions for the survey.

1. Check all the accelerated construction techniques below that you currently employ to expedite construction process. (e.g. materials, equipment, or construction methods)

2. What were the reasons for employing accelerated construction technique(s)?

3. Please describe any technical or management challenges associated with these practices.

4. Describe letting, contract issues and project characteristics that affect construction time and costs associated with accelerated construction methods.

5. What are the benefits from using accelerated construction methods?

6. What are the disadvantages in accelerated construction methods? 
1. Check all the accelerated construction techniques below that you currently employ to expedite construction process. (e.g. materials, equipment, or construction methods)

Based on the responses summarized in Table 9, rapid setting concrete, pre-casting, and innovative contracting methods such as lane rental, incentive/disincentive, $\mathrm{A}+\mathrm{B}$, etc. are most popular methods to accelerate construction. Only one of the states is currently using roller compacted concrete as a means to expedite pavement construction. These survey responses also reveal there are not many others methods currently employed for accelerating construction other than previously defined seven methods.

Table 9 State Transportation Agencies Survey Result

\begin{tabular}{|c|c|c|c|c|c|c|c|}
\hline Stage Agency & $\mathrm{PAD}^{1}$ & $\mathrm{RCC}^{2}$ & $\mathrm{RSC}^{3}$ & $\mathrm{PCM}^{4}$ & $\mathrm{ABC}^{5}$ & $\mathrm{OSC}^{6}$ & $\mathrm{ICM}^{7}$ \\
\hline Michigan & $\mathrm{x}$ & & $\mathrm{x}$ & & & & $\mathrm{x}$ \\
\hline Texas 1 & $\mathrm{X}$ & & $\mathrm{x}$ & $\mathrm{X}$ & & $\mathrm{x}$ & $\mathrm{x}$ \\
\hline Texas 2 & & & $\mathrm{x}$ & & & & $\mathrm{x}$ \\
\hline Montana 1 & $\mathrm{X}$ & & $\mathrm{X}$ & & & & $\mathrm{x}$ \\
\hline Montana 2 & & & & & & & $\mathrm{x}$ \\
\hline Florida & $\mathrm{X}$ & & & $\mathrm{X}$ & $\mathrm{X}$ & $\mathrm{x}$ & $\mathrm{X}$ \\
\hline Idaho & & & & & & & $\mathrm{x}$ \\
\hline Kansas & $\mathrm{x}$ & & $\mathrm{x}$ & & & & \\
\hline Louisiana & $\mathrm{X}$ & & $\mathrm{x}$ & $\mathrm{X}$ & $\mathrm{X}$ & $\mathrm{X}$ & \\
\hline West Virginia & & & $\mathrm{x}$ & $\mathrm{x}$ & $\mathrm{x}$ & & \\
\hline Colorado & $\mathrm{X}$ & $\mathrm{X}$ & $\mathrm{x}$ & $\mathrm{X}$ & & & $\mathrm{x}$ \\
\hline Pennsylvania & & & $\mathrm{x}$ & & & & $\mathrm{x}$ \\
\hline Ontario & & & $\mathrm{x}$ & $\mathrm{x}$ & $\mathrm{x}$ & & $\mathrm{x}$ \\
\hline Maine & & & $\mathrm{x}$ & $\mathrm{X}$ & $\mathrm{x}$ & $\mathrm{x}$ & $\mathrm{x}$ \\
\hline Arkansas & $\mathrm{X}$ & & $\mathrm{x}$ & & & & $\mathrm{x}$ \\
\hline Vermont & & & & $\mathrm{X}$ & $\mathrm{x}$ & & \\
\hline Alaska & & & $\mathrm{x}$ & $\mathrm{X}$ & & & $\mathrm{x}$ \\
\hline Responses & 8 & 1 & 13 & 9 & 6 & 4 & 13 \\
\hline Percentage & $47 \%$ & $6 \%$ & $76 \%$ & $53 \%$ & $35 \%$ & $24 \%$ & $76 \%$ \\
\hline Rank & 4 & 7 & 1 & 3 & 5 & 6 & 1 \\
\hline
\end{tabular}




\footnotetext{
${ }^{1}$ PAD: PCCP with admixture

${ }^{2}$ RCC: Roller compacted concrete

${ }^{3}$ RSC: Rapid setting concrete

${ }^{4}$ PCM: Precast concrete modular construction

5 ABC: Accelerated bridge construction

${ }^{6}$ OSC: Off-site substructure construction

${ }^{7}$ ICM: Innovative contracting methods
}

2. What were the reasons for employing accelerated construction technique(s)? These may include constructability/management issues, construction costs, and user complaints etc.

- Reduce user delays time from traffic backups, lane closures, and/or reduced access to businesses along route.

- Reduce adverse impacts to traffic.

- Shorten construction time and reduce road user costs

- Cost and time savings, contractor performance, value, quality, safety, and reduced user delays.

- Expedite construction.

- To lessen impact on road users

- Mainly construction time and traffic disruption. Construction cost normally increase due to accelerated techniques.

- Interference with the traveling public

- User complaints are the usual reasons.

- Sometimes it is used for emergency contracts.

- Ensure timely, fast, efficient and effective responses to the current challenges and demands of our transportation facilities

- Rapid setting concrete minimizes traffic delays on concrete patching projects.

- Generally to reduce traffic impacts, in some cases to decrease construction costs as well. A few cases are for constructability.

- The main reason is to get in and get out as quickly as possible. For the Traveling Public, time is money (user costs). Closing a bridge to traffic for a relatively short amount of 
time will allow the contractor to work more efficiently and safely. If this can be done, we can often avoid having to use a temporary bridge, which adds cost and time to a project. Many remote sites in Maine result in long detours if a bridge is closed and would require a temporary bridge, using "normal" construction practices. Maine is somewhat unique in that there are many islands that have bridges to the mainland- although replacement of these bridges requires the use of a temporary bridge, it is still usually more cost effective to install a temporary bridge and replace the existing bridge without using staged construction.

- Interstate highway rehabilitation projects. High traffic volumes required accelerated efforts to minimize impacts to the traveling public.

- Reduce the impacts to the travelling public or to decrease the construction time.

- Typical reasons are short term road closures in lieu of maintaining traffic with a temporary bridge, avoid unacceptable level of service in heavy traffic areas using short term lane rentals

3. Please describe any technical or management challenges associated with these practices.

- Equating the user delay cost to the value of payment incentive/disincentive

- Inspecting highly accelerated projects requires adequate staff, both in numbers and in skill level.

- Cost and time disputes are escalated.

- Challenges would be with the contracting industry in accepting the risks that may come with using accelerated construction techniques.

- Can require a higher contract administration level of effort and become contentious between the owner and the contractor especially if the project runs into unforeseen problems or the contract documents are flawed.

- Testing materials, shipping large precast segments, offsite inspection and approving new construction methods with little or no prior information.

- The infrequent use can sometimes bring problems with unfamiliarity and new techniques.

- Internal and external cultural changes and acceptance

- Education

- Normalization/standardization 
- Design build is a paradigm shift for both the DOT personnel and the contracting community. All parties need to buy in to make the process successful.

- Field construction organization and precision are very important. Need to ensure appropriately qualified contractors.

- Challenges include: Getting public buy-in for road closures.

- Scheduling and providing adequate inspection and quality control is difficult due to the extended work hours and the pace required meeting the accelerated schedule.

Additionally the review procedures of field changes have to be expedited beyond the normal review time.

- Alternative contracting is a faster pace and may take additional resources and/or overtime. We include specific "no work" days to help this.

- Technical challenges can be getting folks familiar and comfortable with the new methods; convincing folks the products are equivalent. Also making sure the plans and specifications are bullet proof. Changes to the contract typically involve time and selling the public on increase to the time component can be challenging. Management challenges include proper staffing levels for around the clock operations, accelerated decision making process commensurate with the contractor's activity; containing the scope of the work.

4. Describe letting, contract issues and project characteristics that affect construction time and costs associated with accelerated construction methods.

- The amount of I/D is on a daily basis with a maximum. Thus, the amount is related to the contractor's progress schedule (major work items). Only applies to project of significant scope with pronounced traffic impacts.

- Contract language needs to be written very clearly, with no errors or ambiguities. This is especially important for issues related to contract time.

- Using accelerated construction techniques should help reduce construction time and save costs; however, the contract needs to be clear on the accelerated technique being used.

- Project costs can be higher so are only used when warranted. 
- KDOT lets most of these contracts with calendar completion dates. It writes a special provision for each individual contract, that is every specific to the contract. There are times the special provision will have areas like ramps, bridge, etc that have additional time restraints places on them such as; 30 calendar days to open, work will only be allowed from 8pm till 5 am.

- The construction time is shortened and road user costs are less. Construction costs are generally higher but the savings of road user costs generally offsets these additional costs.

- None other than computing a tighter construction time and CPM review

- The proper advertisement time and the completion of the contract documents can both lead to the delay of the construction thereby shortening the duration allowed to complete the work.

- Incentive clauses can help to expedite the work by providing additional funds to offset the increased labor costs.

- Disincentive clauses will generally raise the unit cost but does establish a firm completion date for the project or phase.

- Design time is significantly reduced pre bid. Post bid the contractor pushed the designer for expedited results.

- For certain initiatives only limited contractors available.

- Issues include: Complicated language required for contracts, such as $A+B$ contracts, to eliminate loopholes; differing subsurface site conditions or necessary changes; delivery time of pre-cast or prefabricated elements; scheduling of subcontractors; timing of letting of contracts to ensure that constraints can be met, such as in-stream work windows, summer traffic avoidance, endangered species requirements (Atlantic Salmon \& ShortNosed Sturgeon).

- The use of an $\mathrm{A}+\mathrm{B}$ or an $\mathrm{A}+\mathrm{C}$ method of determining low bid amount for department contracts has had our greatest affect on construction time and costs from a letting and contract issues standpoint.

- The faster pace requires more constant communications and resolutions (which sometimes is a good thing.) The costs may or may not be higher for construction administration personnel and traffic control (the same amount is there, it just occurs in a shorter time period.) We do not yet know if quality is impacted at all. 
- As mentioned above, the contract language has to be correct and complete. Without these the risk that contractors include with their bid quickly becomes additional profit. The timing of the project advertisement must allow for ample planning so a contractor can get organized and allow enough time for required submittals, public outreach etc.

5. What are the benefits from using accelerated construction methods?

- Improved public relations

- Faster construction, delivery of the final product to the public in reduced time.

- Improved innovation from contractor, especially with regard to sequence of work.

- Reduced user impacts may reduce other costs such as traffic control or engineering costs.

- Reduced work zone related accidents, time savings, cost savings to businesses and users that travel the facility.

- Expedite construction.

- Lessen road user impact.

- Lessen inspection costs and safety.

- Less disruption to the motoring public

- Less disturbance to the traveling public

- Funds are spent in a short duration (less escalation of materials, labor, equipment, etc.)

- Obviously, completing projects with less time to construct, and many times with lesser costs (building with today's cost rates versus future rates)

- Decreased traffic impacts and local community disruptions

- Enhanced innovation

- Reduced traffic impacts, shortened project schedules

- Benefits include: Shorter duration of disruption to traveling public; shorter duration for contractor and MaineDOT employees on site; safer working conditions for contractor, when traffic is eliminated from work zone; potentially higher quality of bridge elements, if prefabricated.

- By minimizing the impact to the traveling public. Reduced exposure to construction zone lowers construction related traffic accidents and the total time delays that the public must endure. 
- It can reduce contract time and decrease impacts to the traveling public. Increased communications can also occur.

- Reduced impacts to the public, perhaps reduced construction engineering costs, may reduce environmental impacts, may eliminate or minimize the need for ROW easements or takings, resulting in a shorter project delivery schedule.

6. What are the disadvantages in accelerated construction methods?

- A likely higher tendency for worker fatigue leading to decreased work quality/oversight. Fatigue can lead to safety concerns such as injury, accidents, etc.

- Potential for decrease in quality of work. Need thorough quality assurance plan and methods to prevent this.

- Increased cost of work.

- Increased pressure on inspection and contract administration personnel.

- In general, cost is greater (than conventional methods).

- Additional construction staffing for inspection and sampling and testing, increased construction costs, added time for the DOT project manager to devote to the project to make timely decisions.

- If too short time frame is given, quality of work can suffer.

- There can be higher initial costs that need to be considered prior to deciding to accelerate.

- Cost and unforeseen construction problems.

- High costs, poor quality workmanship, and higher accident rate.

- Non-traditional way of doing business may encounter resistance.

- More unknowns and therefore potential risks.

- Some require more intensive owner monitoring and involvement due to complexity and risks.

- Disadvantages: The possibility of not meeting the challenges or overcoming the issues listed above; paying high costs for incentives for finishing early; charging the contractor disincentives for not finishing on time, plus the fact that they are not on schedule; long hours and consecutive days of work for contractor and Maine DOT personnel; lack of 
quality of final product if contractor is in too much of a hurry or having to perform work in winter conditions.

- Higher costs for early completion incentives and higher bid prices. Higher inspection costs for the owner due to overtime pay. The accelerated schedules can negatively influence the quality of work, inspection, and quality control resulting in a questionable product.

- It increases the total cost of the contract and can overload the agency and contractor personnel.

- Typically direct costs tend to be greater. Some smaller contractors do not like ACM because they won't gear up staff for the requirements of a few projects and they won't bid, reducing competition. 


\section{Implementation}

The end product will be in the form of a selection table for various classified disruptive activities and their recommended alternatives, which can be used as a planning tool in the PDP. The selection table will consist of the identified disruptive activities, proposed alternatives, and their time and cost data and associated implementation issues. This table will be distributed to planning, design division and design consultants.

\section{$\underline{\text { Time Comparison }}$}

The following tables and figures show the comparisons of time and costs of the items associated in the Indiana Major Moves. All of the materials and methods have been discussed in depth within this final report presented earlier. Table 10 shows the time comparison of materials. All the time values have been converted to hours.

Table 10 Time Comparison: Materials

\begin{tabular}{l|c|c}
\hline \multicolumn{2}{c|}{ Type of Materials } & Hours \\
\hline \hline \multirow{2}{*}{ Admixture } & PCCP (Type I or II) & 72 \\
\cline { 2 - 3 } & RCCP & 72 \\
\hline \multirow{3}{*}{ Rapid Setting } & Air-Entrainment & 72 \\
\cline { 2 - 3 } & Silica Fume & 72 \\
\cline { 2 - 3 } & Migh Molecular Weight Methacrylate (HMWM) & 12 \\
\cline { 2 - 3 } & polyester & 4 \\
\cline { 2 - 3 } & polymer concrete & 4 \\
\hline
\end{tabular}

The most common PCCP in use for roadways is a Type I or II. This concrete generally has a compressive strength of approximately 4,200 psi after 28 days. However, it will have 2,500 psi after 3 days, which would be enough for light traffic if so desired. According to Greg Kicinski of INDOT, INDOT projects allow light traffic on PCCP after 30 hours, so it can be safe to say 
that the pavement can support traffic after 72 hours if the sides are supported with either other pavement or curbs.

Roller Compacted Concrete Pavement (RCCP) is essentially made up the same as PCCP with reduced amount of water in the mix, so the curing time can be the same. Ed Carlson of Nick Savko Construction in Columbus $\mathrm{OH}$ stated multiple axle trucks are allowed on RCCP after 72 hours.

Adding admixtures to the PCCP or RCCP mix generally increases early strengths with the concrete pavement. Air-Entrainment and Silica Fume do not add any strength to the concrete, but aid in other aspects of the mixture. Current practices of INDOT do not use any of these accelerator admixtures because INDOT projects can obtain the same results without these admixtures by having very good control over the aggregate, cement to water ratio and adding a small amount of fly ash.

As noticed there is an incredible amount of time savings with rapid setting concrete, such as MMA (Methyl Methacrylate), HMMA High Molecular Weight Methacrylate), polyester, and polymer concrete. Especially, MMA cures within extremely short period of time compared with regular PCCP. Generally, these epoxies are spread in a thin overlay, less than 0.5 in, over a resurface of a bridge where time is a crucial factor and total closures is not an option. Methyl Metacrylate (MMA) is an industry standard used in applications such as airport runways, bridge overlays, parking garages where time is of the essence. High Molecular Weight Methacrylate (HMWM) is a low odor replacement of MMA for use in areas, particularly indoors, that may not have proper ventilation. Polyester and polymer concretes are also ideally suited for other aspects of the construction trades, outside highway construction.

Hot Mix Asphalt can be cured almost immediately after compaction and cooling by both static and vibratory rollers. In many cases the pavement may be opened to limited traffic prior to this. See Figure 5 for a graphical time comparison of the above materials. 


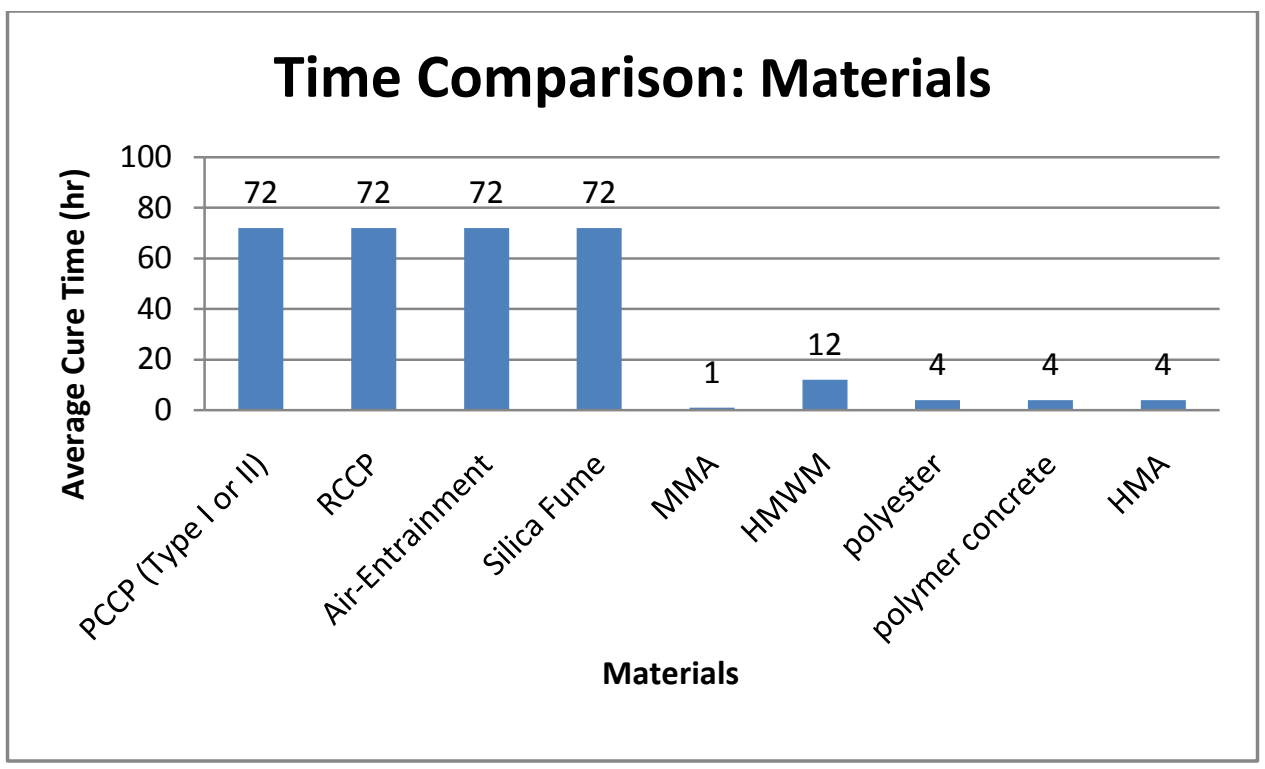

Figure 5 Time Comparison of Materials

Table 11 shows the relative time savings of bridge construction. If a normal bridge construction timetable was $100 \%$, using precast elements can cut the closure time in $50 \%$ of the normal bridge construction time, because the elements are constructed beforehand, shipped to the site, and put together. Then grouting, post-tensioning, and other related construction can finish the bridge. Using an accelerated approach such as replacing the bridge within $2 \%$ of the normal bridge construction time has Utah DOT in the forefront of this approach. The superstructure is built nearby and moved into place with self propelled mobile transports (SPMT) over the span of a couple of days. To date UDOT has 80 bridges built this way and plans on making this type of bridge reconstruction their primary method.

Table 11 Time Comparison: Bridge Construction

\begin{tabular}{c|c}
\hline Type of Bridge Construction & Time (\%) \\
\hline Normal Bridge Construction & 100 \\
\hline Precast Construction Bridge Element & 50 \\
\hline ABC (SPMT) & 2 \\
\hline
\end{tabular}


It must be noted that both of these accelerated bridge constructions techniques employ a learning curve. The first few bridges that are built may not save any time and will cost more. However, as more projects are finished the time and cost saving have been proven to reduce to well below the state engineers' estimates. See Figure 6 for a graphical comparison of time savings in bridge construction.

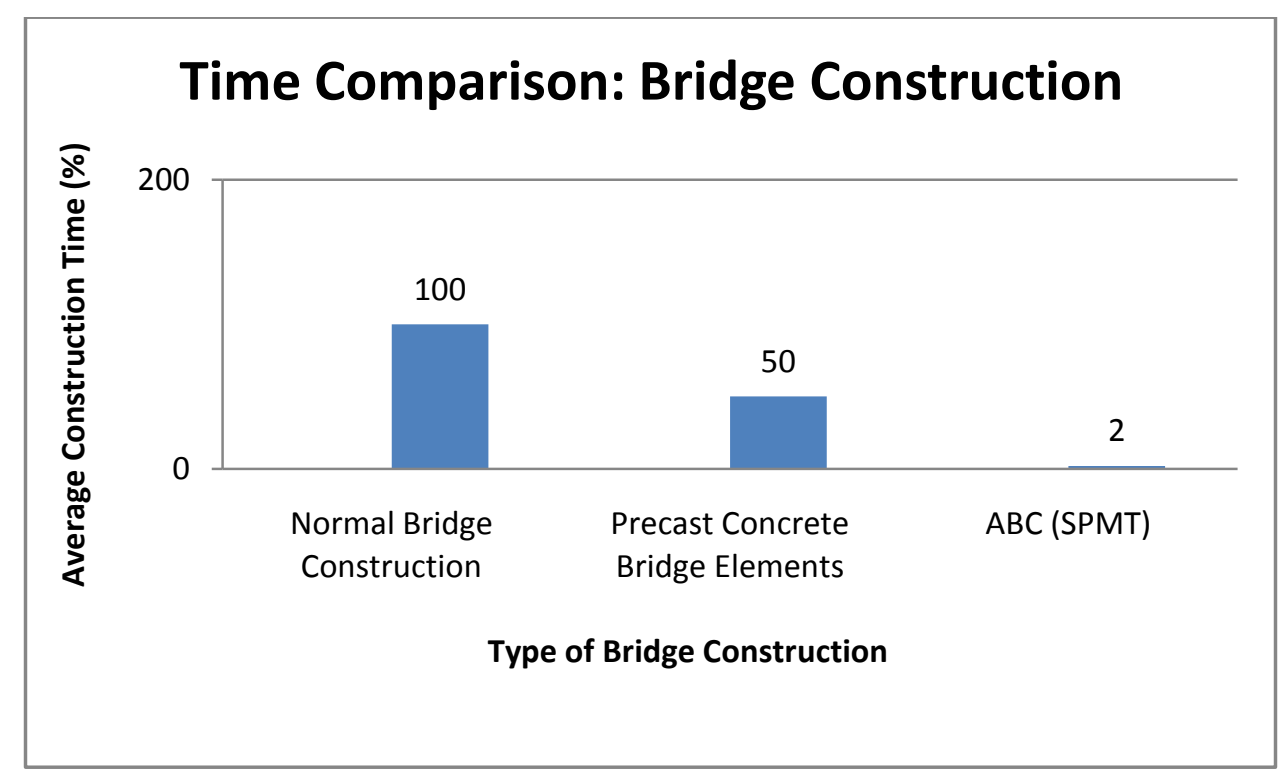

Figure 6 Time Comparison of Bridge Construction Approaches

\section{$\underline{\text { Cost Comparison }}$}

Table 12 gives the cost of PCCP, RCCP, and these with admixtures. It should be mentioned first that in most cases a mixture of additives are added to the cement mix if they are added at all. Each admixture has its strengths and weaknesses and they are combined to maximize the strengths and minimize the weaknesses. The admixtures shown are those that only apply to accelerating the placement of concrete. As it can be seen, the admixtures are relatively inexpensive. As one can see rapid setting admixtures are extremely expensive, and therefore are only used in situations where time is the overriding value. 
Table 12 Cost Comparison: Materials

\begin{tabular}{c|cc}
\hline \multicolumn{2}{c|}{ Type of Materials } & $\$ / \mathrm{yd}^{3}$ \\
\hline \hline \multirow{2}{*}{ Admixture } & PCCP (12”) & 158.1 \\
\cline { 2 - 3 } & RCCP & 73 \\
\hline \multirow{2}{*}{ Rapid Setting } & Air-Entrainment & 158.1 \\
\hline & Silica Fume & 169.7 \\
\hline
\end{tabular}

An example of this is the I-64 bridge over the Mississippi River in St. Louis, MO. It is a vital roadway and when it came time to resurface it, the bridge could not be closed. The bridge was resurfaced over a period of two weekends, at night, closing one lane at a time. See Figure 7 for a graphical comparison of materials costs.

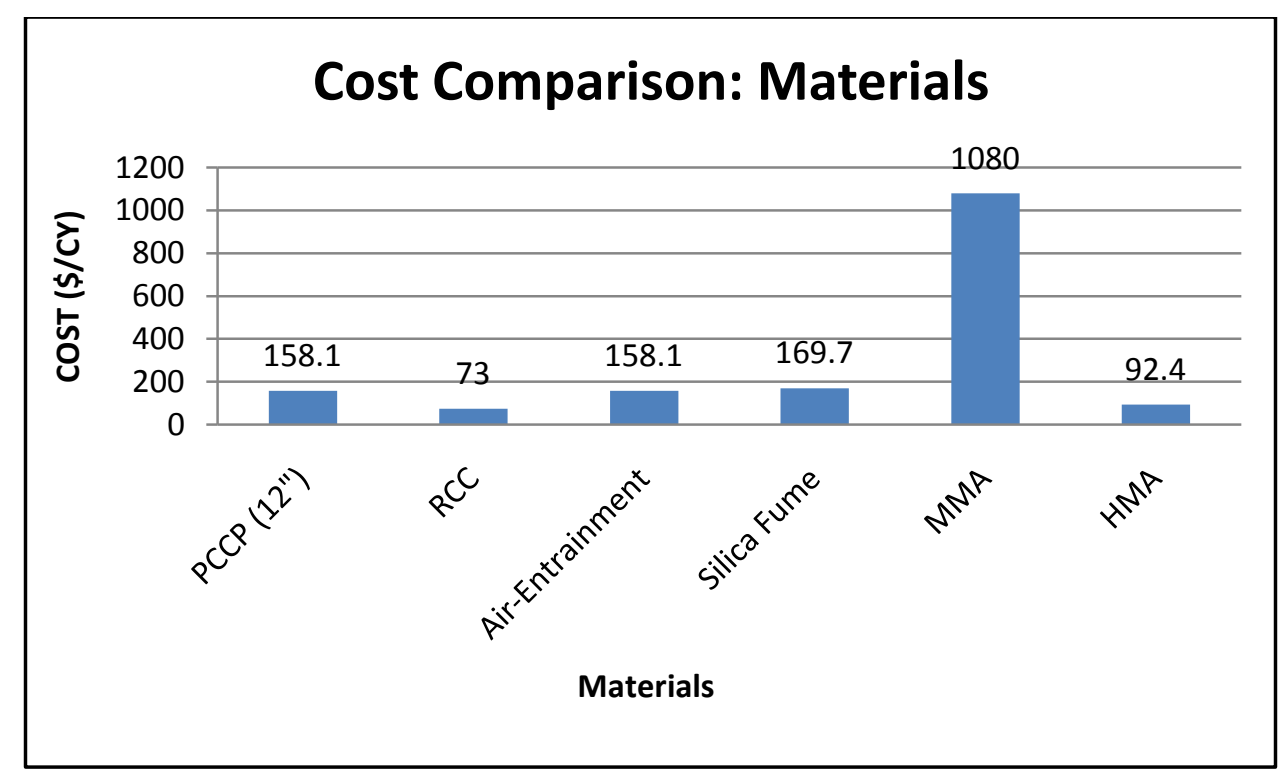

Figure 7 Cost Comparison of Materials 
The costs for bridge construction again are relative and depend upon the familiarity of all parties involved. As with the time comparisons there is a learning curve. This is true with any method. As the engineers, contractors, labor force, and suppliers become accustomed to the method and the pace of construction, costs decrease until they are about half the traditional method for bridge construction. For this reason Utah DOT officials are aggressively pursuing an accelerated bridge construction method for all of their bridge reconstructions. Table 13 shows a cost comparison for difference bridge construction approaches.

Table 13 Cost Comparison: Bridge Construction

\begin{tabular}{c|c}
\hline Type of Bridge Construction & $\$ / \mathrm{ft}^{2}$ \\
\hline Normal Bridge Construction (Utah) & 53 \\
\hline Precast Construction Bridge Element & 31 \\
\hline Normal Bridge Construction (Indiana) & 130 \\
\hline ABC (SPMT) & 470 \\
\hline
\end{tabular}

See Figure 8 for a graphical comparison of the costs of different bridge construction approaches.

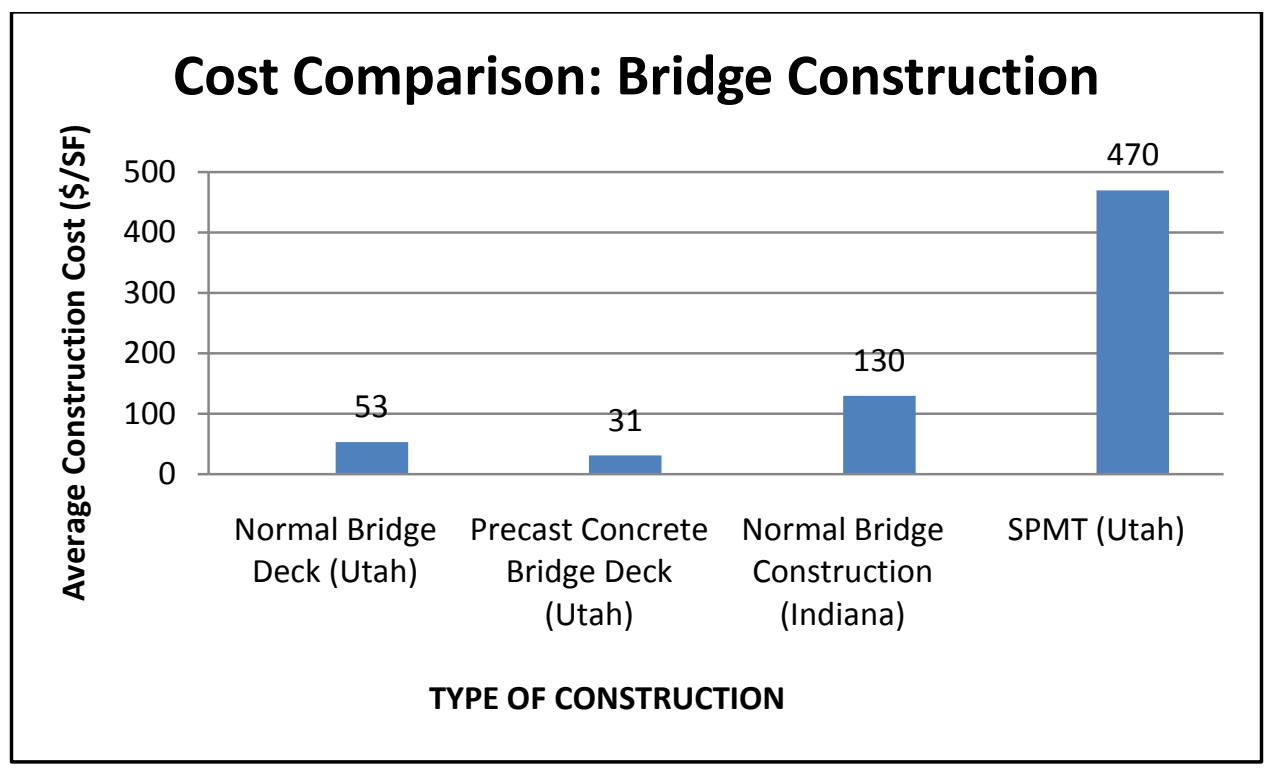

Figure 8 Cost Comparisons of Bridge Construction Approaches 
In reality, there is another savings due to different construction approaches, which is the daily road usage cost (DRUC). In general, the costs and time comparisons depend much on the DRUC evaluating actual practices. However, because this savings is hard to apply to every project due to its uniqueness and can vary widely at different locations, it does not appear on the cost comparisons presented in this report.

\section{$\underline{\text { Unit Cost Analysis }}$}

In this section, described are the "candidate" activities and their corresponding unit costs for materials. As discussed earlier in the report, not all activities can be expedited. Thus, this study only focuses on the activities that can be shortened by the advanced techniques.

By and large, the unit cost of material varies a great deal even within the INDOT contracts. Therefore, the most dominant values (or average values when possible) in the INDOT project data were chosen for this study. Also, since the unit used in the INDOT contracts is different from that of the accelerating techniques, one should use conversion rates to compare those values. For example, the regular cost of HMA base is $\$ 91.79 /$ ton. If one can use natural gravel for the base, its specific gravity is approximately $120 \mathrm{lb} / \mathrm{ft}^{3}$. Thus, $\$ 91.79 /$ ton can be converted to $\$ 50 / \mathrm{yd}^{3}$. In addition, usual unit cost of roller compacted concrete is anywhere from $\$ 65 / \mathrm{yd}^{3}$ to $\$ 80 / \mathrm{yd}^{3}$ ( $\$ 73 /$ ton on average) depending on the type of construction. Thus, one needs additional $\$ 23 / \mathrm{yd}^{3}$ to use RCC as the base for HMA pavement. Table 14 shows those unit conversions needed for comparison. Table 15 compares the unit cost of the current practices with that of advanced techniques. 
Table 14 Unit Cost of Current Practices

\begin{tabular}{|l|l|l|}
\hline \multicolumn{1}{|c|}{ Current Practices } & \multicolumn{1}{|c|}{ Unit Cost } & \multicolumn{1}{|c|}{ Converted Unit cost } \\
\hline HMA base & $\$ 91.79 /$ ton & $\$ 50 / \mathrm{yd}^{3}$ \\
\hline PCCP (12" on average) & $\$ 52.70 / \mathrm{yd}^{2}$ & $\$ 158.1 / \mathrm{yd}^{3}$ \\
\hline RC bridge approach (13”) & $\$ 65.00 / \mathrm{yd}^{2}$ & $\$ 180.66 / \mathrm{yd}^{3}$ \\
\hline Concrete superstructure & $\$ 647.49 / \mathrm{yd}^{3}$ & $\$ 647.49 / \mathrm{yd}^{3}$ \\
\hline Concrete substructure & $\$ 639.26 / \mathrm{yd}^{3}$ & $\$ 639.26 / \mathrm{yd}^{3}$ \\
\hline RC moment slab (12”) & $\$ 98.33 / \mathrm{yd}^{2}$ & $\$ 98.33 / \mathrm{yd}^{2}$ \\
\hline Concrete railing (33”) & $\$ 551.69 / \mathrm{yd}^{3}$ & $\$ 551.69 / \mathrm{yd}^{3}$ \\
\hline HMA base & $\$ 91.79 / \mathrm{ton}^{3}$ & $\$ 50 / \mathrm{yd}^{3}$ \\
\hline PCCP patching full depth (12”) & $\$ 198.48 / \mathrm{yd}^{2}$ & $\$ 595.44 / \mathrm{yd}^{3}$ \\
\hline Concrete barrier (33”) & $\$ 82.00 / \mathrm{ft}^{2}$ & $\$ 115 / \mathrm{yd}^{3}$ \\
\hline PCCP for approaches (9”) & $\$ 54.33 / \mathrm{yd}^{2}$ & $\$ 217.32 / \mathrm{yd}^{3}$ \\
\hline
\end{tabular}

*Specific Gravity: gravel $\left(120 \mathrm{lb} / \mathrm{ft}^{3}\right)$ and concrete $\left(150 \mathrm{lb} / \mathrm{ft}^{3}\right)$ 
Table 15 Comparison of Current Practices and Accelerating Techniques

\begin{tabular}{|c|c|c|c|c|}
\hline \multirow{2}{*}{ Project Type } & \multicolumn{2}{|c|}{ Current Practices } & \multicolumn{2}{|c|}{ Accelerating techniques } \\
\hline & Activities & Unit Cost & Methods & Unit Cost \\
\hline \multirow{2}{*}{$\begin{array}{l}\text { Lanes } \\
\text { construction and } \\
\text { pavement }\end{array}$} & HMA base & $\$ 50 / \mathrm{yd}^{3}$ & $\begin{array}{l}\text { Roller compacted concrete } \\
\text { base }\end{array}$ & Add. $\$ 23 / \mathrm{yd}^{3}$ \\
\hline & PCCP (12" on average) & $\$ 158.1 / y^{3}$ & Concrete admixture & Add. $\$ 11.6 / \mathrm{yd}^{3}$ \\
\hline \multirow{5}{*}{$\begin{array}{l}\text { Bridge } \\
\text { construction and } \\
\text { replacement }\end{array}$} & RC bridge approach (13”) & $\$ 180.66 / \mathrm{yd}^{3}$ & Concrete admixture & Add. $\$ 11.6 / \mathrm{yd}^{3}$ \\
\hline & Concrete superstructure & $\$ 647.49 / \mathrm{yd}^{3}$ & Concrete admixture & Add. $\$ 11.6 / \mathrm{yd}^{3}$ \\
\hline & Concrete substructure & $\$ 639.26 / \mathrm{yd}^{3}$ & Concrete admixture & Add. $\$ 11.6 / \mathrm{yd}^{3}$ \\
\hline & RC moment slab (12”) & $\$ 98.33 / \mathrm{yd}^{2}$ & Precast slab & $\$ 342 / \mathrm{yd}^{2^{*}}$ \\
\hline & Concrete railing (33”) & $\$ 551.69 / \mathrm{yd}^{3}$ & Concrete admixture & Add. $\$ 11.6 / \mathrm{yd}^{3}$ \\
\hline \multirow{5}{*}{$\begin{array}{l}\text { Interchange } \\
\text { construction }\end{array}$} & HMA base & $\$ 50 / \mathrm{yd}^{3}$ & $\begin{array}{l}\text { Roller compacted concrete } \\
\text { base }\end{array}$ & Add. $\$ 23 / y^{3}$ \\
\hline & PCCP (12" on average) & $\$ 158.1 / \mathrm{yd}^{3}$ & Concrete admixture & Add. $\$ 11.6 / y^{3}$ \\
\hline & $\begin{array}{l}\text { PCCP patching full depth } \\
(12 ”)\end{array}$ & $\$ 66.16 / \mathrm{yd}^{3}$ & Concrete admixture & Add. $\$ 11.6 / \mathrm{yd}^{3}$ \\
\hline & Concrete barrier (33”) & $\$ 115 / y d^{3}$ & Concrete admixture & Add. $\$ 11.6 / \mathrm{yd}^{3}$ \\
\hline & PCCP for approaches (9") & $\$ 217.32 / \mathrm{yd}^{3}$ & Concrete admixture & Add. $\$ 11.6 / \mathrm{yd}^{3}$ \\
\hline
\end{tabular}

* Based on a phone interview with Jim McMinimee of UDOT (October 14, 2008), the cost for square foot of a full depth slab was $\$ 63 / \mathrm{ft}^{2}\left(\$ 567 / \mathrm{yd}^{2}\right)$ compared with $\$ 53 / \mathrm{ft}^{2}$ for cast-in-place slab. The cost for a prefabricated full depth slab has dropped to $\$ 38 / \mathrm{ft}^{2}\left(\$ 342 / \mathrm{yd}^{2}\right)$. Here are four examples of prices:

- A project estimated by state engineers to cost $\$ 30 \mathrm{M}$ to replace the deck alone $\Rightarrow$ cost \$29M to replace the whole bridge using SPMT and Alternative Technology Concept (ATC) 
- A bridge estimated to cost $\$ 6 \mathrm{M} \Rightarrow$ cost $\$ 4.5 \mathrm{M}$

- A bridge estimated to cost $\$ 117 \mathrm{M} \Rightarrow$ cost $\$ 114 \mathrm{M}$

- Estimated bridge project $\$ 23 \mathrm{M} \Rightarrow$ cost $\$ 17.8 \mathrm{M}$ and placed within 60 days.

They started down this path because of a lack of carpenters to build the forms. They started the first bridges using 1/2 or partial deck construction (where the partial deck was the form) and finishing with cast-in-place concrete. This saved half the time. Now it appears that all of their bridges will be some sort of ABC but they really like the use of SPMT. They initially had many concerns but they have not had any big problems. Their biggest problem now is the closure pours.

\section{Conclusions}

Accelerating Construction activities have cost implications, typically higher. The reasons are more labor, expensive materials used, and possible more equipment used. However when construction time is reduced, this lowers cost through less contractor overhead and management costs. The methods that are described herein have higher costs with a few exceptions.

This study has several recommendations for INDOT that implemented can reduce construction project cost and time. These recommendations are:

- Pursue innovative contracting techniques. These have proven to encourage contractor innovation and at the same time reduce time and costs. New York DOT has been very successful with these types of contracts and achieved some impressive results and benefits.

- Use other materials that are cost effective

- Roller compacted concrete.

- RCC used as base material. For lower volume roads using RCC as base material for hot mix asphalt pavements can save between $\$ 1.40 / \mathrm{yd}^{2}$ $\$ 2.70 / \mathrm{yd}^{2}$. RCC base is 4.25 " thinner than aggregate base.

- RCC used as base material for PCCP pavement can reduce PCCP thickness by 1 ". 
- RCC used in shoulder construction can save time, and improve safety by minimizing shoulder drop off issues. Also temporary shoulder construction can be accelerated.

- Welded wire reinforcement in concrete construction can save time and money in bridge deck construction, barrier walls, paved ditches and retaining walls.

INDOT should accept this material usage and adopt specifications.

- Accelerated Bridge construction can save time and user costs. Bridges that if taken out of service would cause significant traffic problems and increased user costs, could benefit by using prefabricated bridge components to speed construction or using SPMT to move replacement bridges.

- INDOT needs to cultivate pre-cast companies to setup business in Indiana. Currently the state only has one in-state pre-caster that can produce bridge components(beams and caps). Due to this lack of competition precast costs are higher than they should be.

INDOT is under a lot stress to deliver the Major Moves program on time and within the budget. Due to the economic recession Major Moves money has shrunk resulting in delaying some projects to later years. This is an unavoidable consequence and will probably not face any public outcry. With reduced economic activity lettings will see more bids resulting in lower costs. Market conditions have also brought down fuel and material costs, again proving that economic activity has the most pronounced effect on construction costs.

President-elect Obama will most likely implement a significant infrastructure program that will bring more work to INDOT and INDOT is preparing for it. The recommendations made in this report can bring small savings to INDOT. There is no silver bullet to reducing construction costs. However, now is the time to introduce new ideas and materials because as the work program grows costs will again increase. As the old adage goes, "Every little bit" helps.

The principal investigators are promoting these concepts within INDOT through meetings and personal involvement with decision makers and will continue this effort. INDOT is changing and the recommendations made in this report should be incorporated into the design and construction processes. 


\section{SAC Members}

Dwayne Harris (PA), Research and Development, dharris@indot.in.gov

Mark Miller, Division of Construction Management, mmiller@indot.in.gov

Pankaj Patel, Pavement Engineering, ppatel@indot.in.gov

Lynn Shireman, Milestone Contractors LP, 1ynn.shireman@milestonelp.com

Steve Boyer, Greenfield District, sboyer@indot.in.gov

James Howard, Seymour District, jhoward@indot.in.gov

John Brand; Butler, Fairman and Seufert, (requestor)

Tony DeSimone, FHWA, (317) 226-5307, Anthony.DeSimone@fhwa.dot.gov

Dan Paddock, E\&B Paving, dan.paddock@ebpaving.com

Steve Weintraut; Butler, Fairman, and Seufert, Sweintraut@bsfengr.com

Dallas Day, Fox Contractors, dday@foxcontractors.com

Greg Kicinski, INDOT Project Management, Gkicinski@indot.IN.gov 


\section{References}

1. City of Columbus (2007). Standard Drawings Retrieved November 11, 2008, from http://pubserv.ci.columbus.oh.us/transportation/Document_Library/Standards/2007_STD DWGS.pdf

2. Mindess, Young, \& Darwin. Concrete. $2^{\text {nd }}$ edition (2003). Pearson Education, Inc.

3. Gale Group (2003). "Just a matter of time - Special Advertising Section - concrete repair and construction, scheduling technique and strategy" Retrieved November 1, 2007, from http://findarticles.com/p/articles/mi_m0NSX/is_6_47/ai_91040215/print

4. Portland Cement Association, "Roller Compacted Concrete (RCC) Pavement Research" Retrieved February 6, 2008, from http://www.cement.org/pavements/pv_rcc_research.asp

5. U.S. Army Corp of Engineers, Engineering and Design, "Roller Compacted Concrete" Manual No.1110-2-2006, January 15, 2000

6. U.S. Department of Transportation, Federal Highway Administration (July 2006), "Prefabricated Bridge Elements and Systems"; Retrieved November 1, 2007, from http://www.fhwa.dot.gov/BRIDGE/prefab/script.htm

7. Precast/Prestressed Concrete Institute "Aspire, The Concrete Bridge Magazine" Spring 2008, Retrieved April 22, 2008 from http://www.aspirebridge.org/pdfs/magazine/issue_06/ASPIRE_spring08.pdf

8. U.S. Department of Transportation, Federal Highway Administration (December 2007), "The ABCs of a Rapid Bridge Replacement in Utah:; Retrieved October 14, 2008, http://www.tfhrc.gov/FOCUS/dec07/01.htm

9. U. S. Department of Transportation, Federal Highway Administration, "Framework for Prefabricated Bridge Elements and Systems (PBES) Decision-Making", December 07, 2005, retrieved September 7, 2008 from http://www.fhwa.dot.gov/bridge/prefab/if06030.pdf

10. McMinimee, J., AASHTO, “Accelerated Bridge Construction Presentation”, AASHTO Spring Meeting, May 4-8, 2008, Retrieved August 28, 2008 from http://www.transportation.org/meetings/presentations/springmeeting2008/Accelerated\%2 0Bridge\%20Construction\%20Presentation.pdf

11. Precast Concrete Institute, Northeast Technical Bridge Committee, "Guideline for Accelerated Bridge Construction Using Precast/Prestressed Concrete Components", 2006, Retrieved September 7, 2008, from http://www.pcine.org/view file.cfm?dir=|resourcesldesign tools $\backslash 165 \backslash \&$ filename=Acceler ated_Bridge_Guidelines.pdf 
12. Dumas, C., Mansukhani, S., Porbaha, A., Short, R., Cannon, R., McLain, K., et al., American Trade Initiatives, "Innovative Technology for Accelerated Construction of Bridge and Embankment Foundations in Europe", September 2003, retrieved August 28, 2008 from http://isddc.dot.gov/OLPFiles/FHWA/010940.pdf

13. U.S. Department of Transportation, Federal Highway Administration "BRIEFING FHWA Initiatives to Encourage Quality Through Innovative Contracting Practices Special Experimental Projects NO.14" March 11, 2005, Retrieved April 24, 2008, from http://www.fhwa.dot.gov/programadmin/contracts/sep_a.htm

14. Kent, David, "Innovative Contracting Techniques that Consider Driver Impact, Use of A+B Bidding" July 15, 2008, New York State Department of Transportation, http://ops.fhwa.dot.gov/wz/workshops/accessible/Kent_MWZWB.htm

15. Herbsman, Chen, \& Epstein "Time is Money: Innovative Contracting Methods in Highway Construction” Journal of Construction Engineering and Management, September 1995.

16. U.S. Department of Transportation, Federal Highway Administration, "HIGHWAYS for LIFE Program” 2008, Retrieved April 22, 2008, from http://www.fhwa.dot.gov/hfl/index.cfm

17. CTC \& Associates LLC, "Nighttime Highway Construction” July 30, 2002, Wisconsin DOT RD \& T Program.

18. Carpenter, Fekpe \& Gopalakrishna, "Performance Based Contracting for the Highway Construction Industry” February 2003, Battelle, Retrieved July 28, 2008, www.ncppp.org/resources/papers/battellereport.pdf

19. Thompson, Stuart, "Determining Innovative Contracting Methods to Reduce User Costs" Retrieved July 28, 2008, Utah Technology Transfer Center, http://ops.fhwa.dot.gov/wz/workshops/originals/Stuart\%20Thompson.ppt

20. Ohio Concrete, August 2008 


\section{Appendix A Cost and Time Comparison}

\begin{tabular}{|c|c|c|c|c|c|c|}
\hline Methods & Sub-items & Cost & Time & Positives & Negatives & Sources \\
\hline PCCP & Regular & $\$ 100 \sim 110 / y^{3}$ & 28 day curing & $\begin{array}{l}\text { - Most commonly used } \\
\text { - Relatively inexpensive } \\
\text { - Life expectancy is 40- } \\
\text { 50 years }\end{array}$ & & $\begin{array}{l}\text { Smith Ready Mix, } \\
\text { Valparaiso, IN }\end{array}$ \\
\hline \multirow{5}{*}{$\begin{array}{l}\text { PCCP with } \\
\text { Admixtures }\end{array}$} & Air-Entrainment & & & $\begin{array}{l}\text { - Increased freeze-thaw } \\
\text { durability } \\
\text { - Tiny air bubbles added } \\
\text { to the mixture }\end{array}$ & & \\
\hline & Silica Fume & $\$ 0.25 \sim 0.28 / \mathrm{lb}$ & & $\begin{array}{l}\text { - Improved compressive } \\
\text { and bonding strength } \\
\text { - Reduced permeability } \\
\text { - Improved abrasion } \\
\text { resistance } \\
\text { - Help protect rebar from } \\
\text { corrosion }\end{array}$ & & \\
\hline & $\begin{array}{l}\text { Calcium Chloride } \\
\mathrm{CaCl}_{2}\end{array}$ & $\begin{array}{l}1 \% \pm \$ 1.90 / \mathrm{yd}^{3} \\
2 \% \pm \$ 3.80 / \mathrm{yd}^{3}\end{array}$ & $\begin{array}{l}\text { Compressive and } \\
\text { flexural strength } \\
\text { at early stages }\end{array}$ & $\begin{array}{l}\text { - Most common for rapid } \\
\text { setting } \\
\text { - Increased workability } \\
\text { - Reduced bleeding } \\
\text { - Higher resistance to } \\
\text { freeze-thaw }\end{array}$ & $\begin{array}{l}\text { - Not appropriate in } \\
\text { hot weather } \\
\text { - Some shrinkage } \\
\text { (solved with } \\
\text { sodium sulfate) } \\
\text { - Significant } \\
\text { corrosion of } \\
\text { embedded metals }\end{array}$ & $\begin{array}{l}\text { Smith Ready Mix, } \\
\text { Valparaiso, IN }\end{array}$ \\
\hline & $\begin{array}{l}\text { Triethanolamine } \\
\mathrm{N}\left(\mathrm{C}_{2} \mathrm{H}_{4} \mathrm{OH}\right)_{3}\end{array}$ & $\$ 5.00 / \mathrm{gal}$ & Initial set $1-4 \mathrm{hrs}$ & & 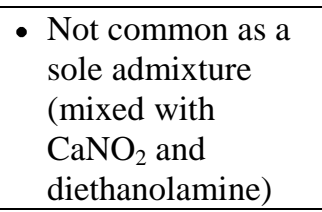 & \\
\hline & $\begin{array}{l}\text { Calcium Formate } \\
\mathrm{Ca}(\mathrm{OOOCH})_{2}\end{array}$ & & & - Corrosion inhibitor & $\begin{array}{l}\text { - Less effective than } \\
\text { other admixtures; } \\
\text { higher doses } \\
\text { needed } \\
\text { - Not common in } \\
\text { construction }\end{array}$ & \\
\hline
\end{tabular}




\begin{tabular}{|c|c|c|c|c|c|c|}
\hline Methods & Sub-items & Cost & Time & Positives & Negatives & Sources \\
\hline \multirow{2}{*}{$\begin{array}{l}\text { PCCP with } \\
\text { Admixtures } \\
\text { (continued) }\end{array}$} & $\begin{array}{l}\text { Calcium Nitrate } \\
\mathrm{CaNO}_{2}\end{array}$ & $\$ 5.00 / \mathrm{gal}$ & Initial set $1-4 \mathrm{hrs}$ & $\begin{array}{l}\text { - Accelerated hydration } \\
\text { - Used for many years } \\
\text { - Corrosion inhibitor } \\
\text { - Increased strength in } \\
\text { early stages } \\
\end{array}$ & & \\
\hline & $\begin{array}{l}\text { Calcium } \\
\text { Thiosulfate } \mathrm{CaS}_{2} \mathrm{O}_{3}\end{array}$ & & & $\begin{array}{l}\text { - Increased strength in } \\
\text { early stages } \\
\text { - Corrosion inhibitor }\end{array}$ & $\begin{array}{l}\text { - Not as effective as } \\
\text { other admixtures } \\
\text { - Not common in } \\
\text { construction }\end{array}$ & \\
\hline \multirow[b]{2}{*}{$\begin{array}{l}\text { Rapid Setting } \\
\text { Concrete }\end{array}$} & $\begin{array}{l}\text { Methyl } \\
\text { Methacrylate } \\
\text { (MMA) }\end{array}$ & $\begin{array}{l}\$ 120 / \mathrm{ft}^{3} \text { (plus } \\
\text { aggregate and } \\
\text { primer) }\end{array}$ & $\begin{array}{l}\text { Over } 8000 \mathrm{psi} \\
\text { after } 60 \mathrm{~min}\end{array}$ & $\begin{array}{l}\text { - Most widely used } \\
\text { - Low viscosity } \\
\text { - Impenetrable to water } \\
\text { (high freeze-thaw } \\
\text { resistance) } \\
\text { - Good resistance to } \\
\text { many acids and } \\
\text { chemicals } \\
\text { - High strength } \\
\text { - Well bonding to any } \\
\text { dry surface }\end{array}$ & $\begin{array}{l}\text { - Moisture sensitive } \\
\text { (aggregate and } \\
\text { substrate must be } \\
\text { dry) } \\
\text { - Moderate } \\
\text { shrinkage } \\
\text { - Highly flammable } \\
\text { - Strong sharp order }\end{array}$ & $\begin{array}{l}\text { Transpo Industries, } \\
\text { New Rochelle, NY }\end{array}$ \\
\hline & $\begin{array}{l}\text { High Molecular } \\
\text { Weight } \\
\text { Methacrylate } \\
\text { (HMWM) }\end{array}$ & $\begin{array}{l}\$ 225 / \text { gal (plus } \\
\text { aggregate and } \\
\text { primer) }\end{array}$ & $\begin{array}{l}\text { Over } 2900 \text { psi } \\
\text { after } 12 \text { hours }\end{array}$ & $\begin{array}{l}\text { - Moderate viscosity } \\
\text { - High strength } \\
\text { - Good water resistance } \\
\text { - Very good binder (used } \\
\text { widely in polymer } \\
\text { mortar systems) } \\
\text { - Suitable for toppings, } \\
\text { overlays, and small } \\
\text { patches } \\
\text { - Excellent acid and } \\
\text { chemical resistance } \\
\text { - Wide range of modulus } \\
\text { of elasticity } \\
\text { - Low volatility }\end{array}$ & $\begin{array}{l}\text { - Very expensive } \\
\text { - Moisture sensitive } \\
\text { (aggregate and } \\
\text { substrate must be } \\
\text { dry) }\end{array}$ & $\begin{array}{l}\text { Sika International; } \\
\text { McCann Distributors, } \\
\text { Chicago, IL }\end{array}$ \\
\hline
\end{tabular}




\begin{tabular}{|c|c|c|c|c|c|c|}
\hline Methods & Sub-items & Cost & Time & Positives & Negatives & Sources \\
\hline \multirow[t]{2}{*}{$\begin{array}{l}\text { Rapid Setting } \\
\text { Concrete } \\
\text { (continued) }\end{array}$} & Polyester & $\begin{array}{l}\$ 1.35 / \mathrm{lb} \text { (plus } \\
\text { aggregate and } \\
\text { primer) }\end{array}$ & $\begin{array}{l}\text { Over } 8000 \text { psi } \\
\text { after } 4 \text { hours }\end{array}$ & $\begin{array}{l}\text { - Low cost } \\
\text { - Primarily used for floor } \\
\text { coating, crack repairs } \\
\text { - Excellent acid and } \\
\text { chemical resistance } \\
\text { - Good water resistance } \\
\text { - Not an epoxy (a resin) }\end{array}$ & $\begin{array}{l}\text { - Oil product } \\
\text { (volatile pricing) } \\
\text { - Moisture sensitive } \\
\text { (aggregate and } \\
\text { substrate must be } \\
\text { dry) } \\
\text { - Significant } \\
\text { shrinkage during } \\
\text { and after setting } \\
\end{array}$ & $\begin{array}{l}\text { AOC/Vicast Resin, } \\
\text { Collierville, TN }\end{array}$ \\
\hline & Polymer Concrete & $\begin{array}{l}\$ 2.50 / \mathrm{lb} \text { (plus } \\
\text { aggregate and } \\
\text { primer) }\end{array}$ & & $\begin{array}{l}\text { - Good water resistance } \\
\text { - Excellent acid and } \\
\text { chemical resistance } \\
\text { - Not an epoxy } \\
\text { - Good abrasion } \\
\text { resistance } \\
\end{array}$ & - Very expensive & $\begin{array}{l}\text { AOC/Vicast Resin, } \\
\text { Collierville, TN }\end{array}$ \\
\hline \multirow{4}{*}{$\begin{array}{l}\text { Asphalt } \\
\text { Concrete }\end{array}$} & $\begin{array}{l}\text { Hot Mix Asphalt } \\
\text { Concrete (HMA) }\end{array}$ & $\begin{array}{l}\$ 56 / \text { ton } \\
\text { (Surface area) }\end{array}$ & & $\begin{array}{l}\text { - Most common used on } \\
\text { roadways }\end{array}$ & $\begin{array}{l}\text { - Life expectancy is } \\
\text { only } 25 \text { to } 30 \\
\text { years } \\
\text { - Done only in } \\
\text { summer months }\end{array}$ & \\
\hline & $\begin{array}{l}\text { Warm Mix Asphalt } \\
\text { Concrete (WMA or } \\
\text { WAM) }\end{array}$ & & & $\begin{array}{l}\text { - Admixture include } \\
\text { zeolite, waxes, or } \\
\text { asphalt emulsions } \\
\text { - Significantly lower } \\
\text { mixing and laying } \\
\text { temperature } \\
\text { - Lower consumption of } \\
\text { fossil fuels (less air } \\
\text { pollution) } \\
\text { - More rapid road } \\
\text { availability (less } \\
\text { disruptive) } \\
\end{array}$ & & \\
\hline & $\begin{array}{l}\text { Cold Mix Asphalt } \\
\text { Concrete (CMA) }\end{array}$ & & & $\begin{array}{l}\text { Soap and water are } \\
\text { added }\end{array}$ & $\begin{array}{l}\text { - Mainly used on } \\
\text { patching and low } \\
\text { traffic roadways }\end{array}$ & \\
\hline & $\begin{array}{l}\text { Cut Back Asphalt } \\
\text { Concrete (CBA) }\end{array}$ & & & $\begin{array}{l}\text { - Kerosene is added to } \\
\text { the binder }\end{array}$ & & \\
\hline
\end{tabular}




\begin{tabular}{|c|c|c|c|c|c|c|}
\hline Methods & Sub-items & Cost & Time & Positives & Negatives & Sources \\
\hline $\begin{array}{l}\text { Roller } \\
\text { Compacted } \\
\text { Concrete }\end{array}$ & & $\$ 1.28 / \mathrm{yd}^{3}$ & & $\begin{array}{l}\text { - Very low initial cost } \\
\text { - High strength and } \\
\text { durability } \\
\text { - High production with } \\
\text { minimal labor } \\
\text { - Open to traffic after } 48 \\
\text { hr } \\
\end{array}$ & $\begin{array}{l}\text { - Very rough } \\
\text { surface (usually } \\
\text { used in off- } \\
\text { highway or low } \\
\text { speed } \\
\text { applications } \\
\text { - Not as PCCP }\end{array}$ & \\
\hline $\begin{array}{l}\text { Precast Modular } \\
\text { Concrete }\end{array}$ & & $\begin{array}{l}\text { Approx. } 20 \% \\
\text { cost savings for } \\
\text { shorter bridges } \\
(<35 \mathrm{ft}) \\
\text { Cost gap } \\
\text { reduces to zero } \\
\text { at about } 165 \mathrm{ft} \\
\end{array}$ & $\begin{array}{l}\text { Girders/culverts - } \\
\text { same as steel } \\
\text { Much faster than } \\
\text { cast in place }\end{array}$ & $\begin{array}{l}\text { - Built offsite in a } \\
\text { controlled environment } \\
\text { - Safer than cast in place } \\
\text { - Less disruptive to the } \\
\text { surrounding } \\
\text { environment }\end{array}$ & $\begin{array}{l}\text { - Very limited to } \\
\text { bridge/overpass } \\
\text { construction }\end{array}$ & $\begin{array}{l}\text { Precast/Prestressed } \\
\text { Concrete Institute } \\
\text { (Heinrich O. Bonstedt) }\end{array}$ \\
\hline \multirow{4}{*}{$\begin{array}{l}\text { Innovative } \\
\text { Contract } \\
\text { Methods }\end{array}$} & Cost/Time $(\mathrm{A}+\mathrm{B})$ & $\begin{array}{l}\text { estimated } \\
\text { project cost }+ \\
\text { daily road user } \\
\text { cost } \times \\
\text { estimated } \\
\text { project } \\
\text { duration } \\
\end{array}$ & & $\begin{array}{l}\text { - Recommended by FHA } \\
\text { and } 16 \text { state agencies } \\
\text { - Substantial time } \\
\text { reduction with no } \\
\text { increased overall cost }\end{array}$ & & \multirow{4}{*}{$\begin{array}{l}\text { Mime is Money: } \\
\text { Innovative Contracting } \\
\text { Methods in Highway } \\
\text { Construction by Z. } \\
\text { Herbsman et. al. } \\
\text { (1995) }\end{array}$} \\
\hline & $\begin{array}{l}\text { Incentive/Disince } \\
\text { ntive (I/D) }\end{array}$ & & & $\begin{array}{l}\text { - Most established method } \\
\text { among contractors }\end{array}$ & & \\
\hline & Cost/Time + I/D & & & $\begin{array}{l}\text { - Guaranteed lower } \\
\text { project cost proposed by } \\
\text { the contractor }\end{array}$ & & \\
\hline & Lane Rental & & & $\begin{array}{l}\text { - Tighter schedule } \\
\text { - More organized work } \\
\text { force }\end{array}$ & & \\
\hline $\begin{array}{l}\text { Nighttime/Off } \\
\text { Peak } \\
\text { Construction }\end{array}$ & & $\begin{array}{l}\text { Increased cost } \\
\text { due to } \\
\text { overtime/night } \\
\text { premium pay } \\
\text { rates }\end{array}$ & & $\begin{array}{l}\text { - Cooler temperatures } \\
\text { better for concrete } \\
\text { placing }\end{array}$ & $\begin{array}{l}\text { - Noise, vibration, } \\
\text { and illumination } \\
\text { - Dependent on } \\
\text { type of work, } \\
\text { contractor's } \\
\text { experience, and } \\
\text { location } \\
\text { - Additional } \\
\text { training needed } \\
\end{array}$ & \\
\hline
\end{tabular}




\title{
Appendix B INDOT Project Managers and Designers Survey Questionnaire
}

\author{
ICA Survey
}

INDOT has a research project through Purdue University to investigate "Accelerated Construction Techniques and Cost Implications." One objective is to assist Major Moves by bringing projects on-time and within the projected budget. Contractors play a big part in this through innovation. This survey attempts to collect a contractor's perspective on accelerating construction and the impact on construction costs.

1. Describe common constructability issues that you experience with design. These are issues that cause construction costs and time to increase

2. Describe letting and contract issues and project characteristics that affect construction time and costs.

3. Provide examples on accelerating construction activities through the use of materials (e.g. precast items, rapid setting concrete, etc.), equipment, and construction methods.

Please return by June 6 to Bob McCullouch P.E., Ph.D. either through email at bgm@purdue.edu or by mail to: Bob McCullouch

Purdue University

School of Civil Engineering

550 Stadium Mall Drive

West Lafayette, IN 47907 


\section{Appendix C State Transportation Agencies Survey Questionnaire}

\section{Accelerated Construction Techniques Questionnaire}

The Indiana Department of Transportation (INDOT) and Joint Transportation Research Program (JTRP) at Purdue University needs your assistance with a research project investigating "Accelerated Construction Techniques and Cost Implications." One objective is to identify what methods are being used by other state highway agencies to expedite highway/bridge constructions. This survey also attempts to collect the impacts on construction costs due to the acceleration technique. Please answer the questionnaire and return through email to one of the below email addresses. Thank you for your assistance.

Bob McCullouch, Ph.D., P.E.

School of Civil Engineering, Purdue University

550 Stadium Mall Drive, West Lafayette, IN 47907

Phone 765- 494-0643

Emailbgm@purdue.edu

Jay Lee, Ph.D., P.E.

School of Technology, Purdue University Calumet

$2200169^{\text {th }}$ Street, Hammond, IN 46323

Phone 219-989-3225

Email leej@calumet.purdue.edu

Thank you in advance for your assistance with our project.

1. Check all the accelerated construction techniques below that you currently employ to expedite construction process. (e.g. materials, equipment, or construction methods)

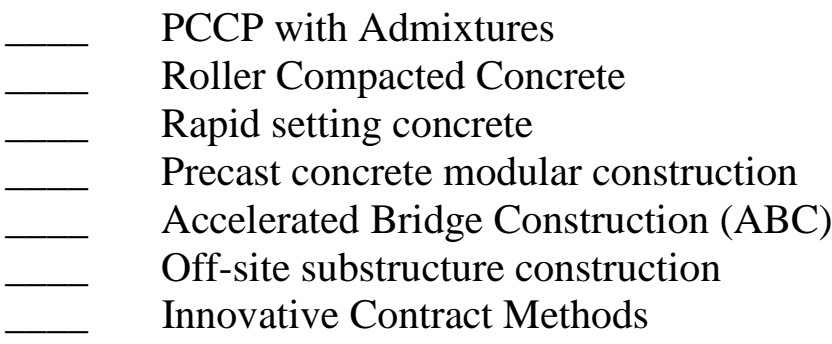

Other (please specify) 
2. What were the reasons for employing accelerated construction technique(s)? These may include constructability/management issues, construction costs, and user complaints etc.

3. Please describe any technical or management challenges associated with these practices.

4. Describe letting, contract issues and project characteristics that affect construction time and costs associated with accelerated construction methods. 
5. What are the benefits from using accelerated construction methods?

6. What are the disadvantages in accelerated construction methods?

7. Would you like to receive a copy of the result of this survey?

_ Yes_ No

8. May we contact you to collect more information about your accelerated construction techniques?

_ Yes_ _ No

Name:

Address/State/Zip:

Phone: Email:

Agency name 
Thank you for your time. 


\section{Appendix D Meeting Minutes}

Review Construction Techniques for Accelerated Construction SAC Meeting - April 8, 2008

On this date a SAC meeting was held at the Traffic Management Center in Indianapolis. The meeting started at 9:30 and the following were in attendance:

James Howard

INDOT

Steven Boyer

INDOT

Tony DeSimone

FHWA

Stephen Weintraut

Mark Miller

Butler, Fairman and Seufert

Jay Lee

INDOT

Bob McCullouch

Purdue - Calumet

Purdue

The meeting started with a description of INDOT's goals and the Commissioner's request. The project's objectives and activities were described. One objective is to produce a product that can be implemented. After presenting this information a discussion started on the project schedule, activities and Implementation outcome. Discussion included the following:

- The Indiana precasting market is very limited; Precasting Services is the only major supplier. Precasting costs have increased significantly over the last five years in Indiana. This is significantly affecting using this option as a method for accelerating construction while monitoring costs.

- Accelerating construction and increasing costs are usually related. However, one objective of this project is to analyze cost implications with construction techniques.

- Another aspect is to minimize disruptions to traffic and the impact of MOT on contractor operations.

- There are many aspects to this study, some are: nighttime construction costs, multiple season projects and the timing of lettings, utilities and other preconstruction activities, off-site fabrication and its timing, design to minimize labor costs and to include constructability issues.

- Possible implementation products are a decision tree and promoting a few innovative ideas and their corresponding implications on design procedures and specifications.

Action Items:

1. Need additional SAC members from the contracting industry and INDOT project management group.

2. Meet with ICA and ACEC to discuss project and receive input.

3. Study current practices through searches and a survey distributed to agencies. 
4. Evaluate major moves project listing

The next meeting is scheduled for June 12 at 8:00 with location to be determined. 
Review Construction Techniques for Accelerated Construction SAC Meeting - June 12, 2008

On this date a SAC meeting was held at the Traffic Management Center in Indianapolis.

The meeting started at 8:00 and the following were in attendance:

Dan Paddock

Martin Pritchett

E\&B Paving

James Howard

INDOT

Tony DeSimone

INDOT

Stephen Weintraut

FHWA

Mark Miller

Butler, Fairman and Seufert

Jay Lee

Bob McCullouch

INDOT

Purdue - Calumet

Purdue

The meeting started with a review of the last SAC meeting outcomes and action items.

Discussions were the following items:

- Two new SAC members were added from the construction industry: Dan Paddock of E\&B paving and Dallas Day from Fox Contracting.

- Only three surveys have been returned, all contractors. ACEC will be contacted to promote the return of the survey.

- Another precasting company is considering relocating in Indiana.

- Shorter duration projects reduce price risks for contractors. For example, asphalt has had 4 increases in the last 45 days.

- More standardization in projects helps to increase productivity and reduce costs. For example, different pavement mixtures and cross sections.

- Accelerated concrete mixtures may be making concrete more brittle.

- Let bridge work ahead of road contract.

- Allow for alternative bidding, precast or cast-in-place for bridges.

- The new utility rule should start showing improved utility relocations in the near future.

Action Items:

1. Contact Beth Bauer at ACEC about lack of survey responses.

2. Check with other state agencies on their use of RCC (roller compacted concrete) pavement.

3. Collect unit cost info from INDOT, Mark will provide.

4. Investigate and collect more info on the use of prebuilt bridges that are rolled into place and on precast bridge components.

5. Find out about Highways for Life application at INDOT. Also, check on the workshop that is being advertised for Indy. 
6. Investigate the use of $\mathrm{A}+\mathrm{B}$ contracting by INDOT. INDOT stopped their use several years ago. Find the contracts and talk with contractors involved in those contracts. INDOT will provide the contract info.

7. Multiple season projects cost money to winterize. Look at Hyperfix project report and retract info on what made this a successful approach.

8. Survey other states on accelerated construction techniques, safety specifications used on accelerated contracts, and on contractor review of design documents. 
Review Construction Techniques for Accelerated Construction SAC Meeting - October 17,2008

On this date a SAC meeting was held at the Traffic Management Center in Indianapolis. The meeting started at 9:00 and the following were in attendance:

Greg Kicinski INDOT

Dwayne Harris INDOT

Jay Lee Purdue - Calumet

Bob McCullouch Purdue

The meeting started with a review of the last SAC meeting outcomes and action items. Discussions were the following items:

- Major Moves: Major moves were discussed based on Mar Miller's input. Among 13 major project types, this study focuses on four types (lanes construction and pavement, bridge construction and replacement, interchange construction, and drainage rehabilitation).

- Meeting with ICA and ACEC: Are meetings with Beth Bauer necessary?

- Survey other State agencies on accelerating construction: Among seven major current practices, top three are Innovative contracting methods, rapid setting concrete, and precast concrete modular construction.

- Roller compacted concrete (RCC): Not many States are using RCC pavement on the main lane. Among the 17 survey respondents, Colorado is the only State using it.

- Unit costs of INDOT projects: Greg Kicinski will review the unit cost table.

- Accelerated bridge construction (ABC): pros and cons of ABC were discussed and included in the interim report.

- Highways for Life: Indiana does not consider Highways for Life.

- $\mathrm{A}+\mathrm{B}$ by Indiana: Greg Kicinski talked about $\mathrm{A}+\mathrm{B}$. It is a consensus that INDOT needs training contractors and engineers to help them better understand $\mathrm{A}+\mathrm{B}$ and its application in INDOT projects.

- Hyperfix: Lessons learned from Hyperfix. Currently INDOT runs a total-closure project in Northwestern Indiana on I-65. Many are proponent to this approach because of its many benefits in management and operations.

- Precasting industry options: There was a meeting with McCann Concrete Products, Dorsey, IL on Sept. 18, 2008. Mark Miller, Anne Rearick, and Bob McCullouch attended.

Action Items:

1. Greg Kicincki recommended a hypothetical study on the top layer thickness design with RCC base material. 
2. Greg Kicinski will review the summary of the INDOT project unit costs discussed in the SAC meeting.

3. It is recommended the project include the study of $\mathrm{ABC}$ cost info such as the unit cost of the entire bridge construction (roughly estimated $\$ 130 / \mathrm{ft}^{2}$ ), pricing options, and the percentage of a traditional bridge construction cost.

4. To promote $\mathrm{A}+\mathrm{B}$ and accelerating construction techniques, the project team will attend a bi-weekly meeting at the INDOT central office in December, 2008.

Tentatively the meeting to attend is on December $9^{\text {th }}, 2008$. It will be approximately a 30 minute talk. Bob McCullouch will also contact Gary District office to find out an opportunity to meet with them.

5. Suggestions to implementation: Greg Kicinski recommended a study on a specific project with new approaches and their application stages.

The first draft of the final report will be distributed by the end of November, 2008 . 
Review Construction Techniques for Accelerated Construction - Nov 24, 2008, Monday On this date a meeting with construction managers was held at the Government Center in Indianapolis. The meeting started at 8:30 AM and the following were in attendance:

Greg Kicinski

Louis Feagans

INDOT

Gary Mroczka

INDOT

Kimberlee Parker

INDOT

John Pangallo

INDOT

Kenny Fronklin

INDOT

Eryn Fletcher

INDOT

Gary Pence

INDOT

Runfa Shi

INDOT

Trevor Mills

INDOT

Kevin Hetrick

INDOT

David Butts

INDOT

Tim Muench

INDOT

Tom Seeman

INDOT

Jay Lee

INDOT

Bob McCullouch

Purdue-Calumet

Purdue

The meeting started with an overview of the project and outcomes. Discussions were the following items:

- Overview of Indiana Major Moves

- Current practices for accelerating construction at other agencies

- Other state agencies survey results

- Roller compacted concrete (RCC) as base materials and hypothetical design and cost comparisons

- Overview of accelerated bridge construction (ABC) and its options

- Practical issues on galvanized welded wire reinforcement (WWR) and costs

- A+B contracting by Indiana

- What made Hyperfix a successful approach?

- Cost and time comparisons between traditional methods and accelerated construction practices

Suggestions and comments:

1. The construction managers recommended studying on production rates of RCC pavement as main lane, shoulder, and base materials.

2. RCC base materials can be used for temporary pavement or MOT to reduce closing time during operation.

3. More study on the Ohio DOT's RCC thickness design guideline may facilitate its application in the State of Indiana. How can we design the thickness for high volume highways? Check with Georgia DOT about their use of RCC on 
shoulders and obtain their spec. There is interest in using RCC on the shoulder expansion for temporary lane on the upcoming I-69 project.

4. It is recommended that the project include some more study on WWR such as production rates of WWR operations.

5. Contact precast pipe companies and see if they are willing to expand their businesses to bridge construction.

6. Greg Kicinski made a comment that "direct" conversion of time savings to cost savings is very difficult because there are too many variables are involved in project costs and all the variables are unique in each project.

The PowerPoint slides will be distributed to all the participants. 


\section{Appendix E Georgia Department of Transportation Roller Compacted Concrete Pavement}

Section 442-Roller Compacted Concrete Pavement

442.1 General Description

This work includes constructing pavement composed of Roller Compacted Concrete (RCC) on a prepared subgrade or subbase course. Follow the requirements of these Specifications and conform to the lines, grades, thickness, and cross sections shown on the Plans or as directed by the Engineer.

442.1.01 Definitions

General Provisions 101 through 150.

442.1.02 Related References

A. Standard Specifications

Section 106-Control of Materials

Section 430-Portland Cement Concrete Pavement

Section 500 - Concrete Structures

B. Referenced Documents

ASTM C 1435

AASHTO T 22

AASHTO T 180, Method D

QPL 10

GDT 59

442.1.03 Submittals

Submit the following to the Engineer at least 35 days before start of any production of RCC:

\section{A. Concrete Mix Design}

Submit a mix design prepared by a qualified testing laboratory. The Engineer will transmit the design to the Office of Materials and Research for approval.

Include details on aggregate gradation, cementitious materials, admixtures (if used), compressive strengths, required moisture and density to be achieved and quantities of individual materials per cubic yard for the mix design.

B. Paving Plan

Submit paving procedures describing direction of paving operations, paving widths, planned longitudinal and transverse cold joints, curing methods and patterns and description of all equipment.

442.2 Materials

Ensure that materials meet the requirements of the following Specifications: 
Material Section

Coarse Aggregate, Class A or B Crushed Stone or Gravel 800

Fine Aggregate, Size No. 10 801.2.02

Section 442-Roller Compacted Concrete Pavement Page 2

Portland Cement, Type 1 830.2.01

Portland Pozzolan cement 830.2.03

Chemical Admixtures 831.2.02

Fly Ash and Slag 831.2.03

Curing Agents 832

Joint Fillers and Sealers 833

Low Modulus Silicone Sealant for Roadway Construction Joints 833.2.06

Water 880.2.01

A. Fly Ash

Ensure the use of fly ash conforms to Subsection 430.2.A.1, 2 and 4, "Fly Ash" and that the fly ash mix conforms to Subsection 442.3.06, "Quality Acceptance".

B. Granulated Iron Blast-Furnace Slag

Ensure the use of slag conforms to Subsection 430.2.B.1, 2 and 4, "Granulated BlastFurnace Slag" and that the slag mix conforms to Subsection 442.3.06, "Quality Acceptance".

C. Composition of RCC

1. Aggregates

Use aggregates manufactured to meet the gradation at the quarry or blended at the plant site to produce the desired results. Use aggregates that are well graded without gradation gaps and conform to the following gradation:

Sieve Size Percent Passing by Weight

1 in $(25 \mathrm{~mm}) 100$

$3 / 4$ in $(19 \mathrm{~mm}) 90-100$

$1 / 2$ in $(12.5 \mathrm{~mm}) 70-100$

$3 / 8$ in $(9.5 \mathrm{~mm}) 60-85$

No. $4(4.75 \mathrm{~mm}) 40-60$

No. $16(1.18 \mathrm{~mm}) 20-40$

No. $100(150 \mu \mathrm{m}) 6-18$

No. $200(75 \mu \mathrm{m}) 2-8$

Produce evidence that the proportions have the potential for strength development at 28 days as required in Subsection 442.3.06.B, “Approval of Mix Design Proportions".

442.3 Construction Requirements 


\subsubsection{Personnel}

General Provisions 101 through 150.

\subsubsection{Equipment}

Provide equipment and tools to construct RCC that will produce a completed pavement meeting the requirements for mixing, transporting, placing, compacting, finishing, and curing as provided in this specification. All equipment will be on hand and approved by the Engineer before work can proceed.

\section{Section 442-Roller Compacted Concrete Pavement Page 3}

\section{A. Mixing Plant}

Produce an RCC pavement mixture in the proportions defined by the approved mix design and within the specified tolerances.

Capacity of the plant will be sufficient to produce a uniform mixture at a rate compatible with the placement equipment.

1. Pugmill Plant

a. Pugmill plant shall be a central plant with a twin shaft pugmill mixer, capable of batch or continuous mixing.

b. Equip plant with synchronized metering devices and feeders to maintain the correct proportions of aggregates, cement, fly ash and water.

c. The pugmill plant will also meet the following:

1) Aggregate Storage

a. If previously blended aggregate is furnished, storage may be in a stockpile from which it is fed directly to a conveyor feeding mixer.

b. If aggregate is furnished in two size groups, aggregate separation must be provided at the stockpile.

2) Aggregate Bins

a. Control feed rate by a variable speed belt or operate gate calibrated to accurately deliver any specified quantity of material.

b. If two aggregate size stockpile sources are used, the feed rate from each bin shall be readily adjustable to change aggregate proportions, when required.

c. Feed rate controls must maintain the established proportions of aggregate from each stockpile bin when the combined aggregate delivery is increased or decreased.

3) Plant Scales

a. If utilized, for any weigh box or hopper will be either of beam or springless dial type, and be sensitive to 0.5 percent of the maximum load required.

b. Provide beam-type scales that have a separate beam for each aggregate size, with a single telltale actuated for each beam, and a tare beam for balancing hopper.

c. Belt scales will be of an approved design.

d. Provide standard weights accurate to plus or minus 0.1 percent for checking plant scales.

4) Cement, Fly Ash or Slag Material Storage 
a. Provide separate and independent storage silos for Portland cement, fly ash or slag.

b. Identify clearly each silo to avoid confusion during silo loading.

5) Cement, Fly Ash or Slag Feed Unit

To assure a uniform and accurate quantity of cementitious materials enters the mixer, provide satisfactory means of dispensing Portland cement, fly ash or slag, volumetrically or by weight.

6) Water Control Unit

a. Measure by weight or volume the required amount of water for the approved mix.

b. Equip the unit with an accurate metering device.

c. Keep RCC mixture at optimum moisture by having the rate of water added adjustable.

7) Gob Hopper

For continuous operating pugmills, attach a gob hopper to the end of the final discharge belt to temporarily hold the RCC discharge to allow the plant to operate continuously.

Section 442-Roller Compacted Concrete Pavement Page 4

2. Central Mix Batch Plant

Central mix batch plant may be used in RCC work meeting the requirements of Subsection 500.3.04.E of the Specifications.

3. Dry Batch Plant

a. A dry batch plant meeting the requirements of Subsection 500.3.04.E of the Specifications may be used on projects with less than 5000 cubic yards of RCC.

b. RCC may be mixed at a central point or wholly or in part in truck mixers as provided in Subsection 500.3.04.E of the Specifications.

B. Paver

Place RCC with an asphalt paver meeting the following requirements:

1. Equip the paver with compacting devices capable of producing a RCC pavement with a minimum of $90 \%$ of the maximum density in accordance with AASHTO T 180, Method D.

2. Spread and finish the RCC material without segregation, to the required thickness, smoothness, surface texture, cross-section and grade using a paver of suitable weight and stability.

C. Compactors

1. For primary compaction, use self-propelled smooth steel drum vibratory rollers having minimum weight of 10 tons $(9.07 \mathrm{Mg})$.

2. For finish rolling as required for final compaction or for removing roller marks, use a steel drum roller, operating in static mode, a rubber tired roller or combination roller.

3. For compacting areas inaccessible to large rollers, use walk-behind vibratory rollers or plate tampers.

D. Haul Trucks

1. Provide sufficient number of trucks to ensure adequate and continuous supply of RCC material to paver. 
2. Equip trucks hauling RCC material from the plant to the paver with covers to protect the material from inclement weather and to reduce evaporation losses.

E. Water Trucks

1. Throughout the paving and curing process, have at least one water truck or other similar equipment on-site and available.

2. Equip the water truck with a spreader pipe containing fog nozzles capable of evenly applying a fine mist of water to the surface of the RCC without damaging the final surface.

442.3.03 Preparation

Prepare the subgrade/subbase as required by the Plans and Specifications before placing the RCC.

Ensure that the foundation immediately under the RCC pavement and the areas supporting the paving equipment will not contribute to deficient pavement thickness or excessive yield losses.

\subsubsection{Fabrication}

General Provisions 101 through 150.

442.3.05 Construction

A. Mixing RCC

Use the same mix design and materials for the entire project. If the source of cement, fly ash, slag, or aggregates is changed, suspend construction and submit a new mix design to the Engineer for approval.

\section{Section 442-Roller Compacted Concrete Pavement Page 5}

1. Mixing Time

a. Assure complete and uniform mixing of all ingredients.

b. The volume of RCC material in the mixing chamber should not exceed the manufacturer's rated capacity for dry concrete mixtures.

c. Keep sides of the mixer and mixer blade surfaces free of hardened RCC and other materials.

d. Check mixer blades routinely for wear and replace if wear is sufficient to cause inadequate mixing.

2. Mixing Ingredient Tolerances

Ensure that mixing plant receive the quantities of individual ingredients to within the following tolerances:

Material Variation by Weight

Cementitious Materials $\pm 2.0 \%$

Water $\pm 3.0 \%$

Aggregates $\pm 4.0 \%$

3. Plant Calibration

a. Prior to RCC production, provide a complete and comprehensive calibration of the plant in accordance to the manufacturer's recommendation. 
b. Concrete batch plants currently listed on QPL 10, the calibration requirement is waived. Supply daily plant records of production and quantities of materials used that day to the Engineer. These records may be used as a check on plant calibration.

\section{B. Transporting RCC}

Transport RCC pavement material from the plant to the paver as follows:

1. Use dump trucks fitted with retractable protective covers for protection from inclement weather or excessive evaporation.

2. Dump the trucks clean with no buildup or hanging of RCC material in the corners.

3. Deposit the RCC material directly into the hopper of the paver or secondary distribution system which deposits the material into the paver hopper.

C. Placing RCC

1. Subgrade/Subbase Condition

a. Keep subgrade/subbase surface clean and free of foreign material, ponded water and frost prior to RCC placement.

b. Uniformly moisten subgrade/subbase at the time of RCC placement.

c. If the subbase becomes dry, uniformly water, but the method of watering used will not form mud or pools of freestanding water.

2. Paver Requirements

a. Adjust the paver and regulate the speed to prevent segregation and provide a surface course that is smooth and continuous without tears and pulling. Limit the spread of the RCC to a length that can be compacted and finished within the appropriate time limit under the prevailing air temperature, wind, and climatic conditions.

b. Proceed in a steady, continuous operation with minimal starts and stops.

c. Regulate speed to assure a constant supply of RCC material in the hopper.

d. Maintain RCC material above the auger shaft at all times during paving.

Section 442-Roller Compacted Concrete Pavement Page 6

\section{Lift Thickness}

Construct pavements greater than 10 in $(250 \mathrm{~mm})$ in two lifts of equal thickness.

4. Adjacent Lane Placement

a. Place adjacent paving lanes within 60 minutes.

b. If more than 60 minutes has elapsed between placements of adjacent lanes, the vertical joint will be considered a cold joint. Prepare the cold joint in accordance with Subsection 442.3.05.E.2, "Cold Vertical Joints".

c. At the discretion of the Engineer, this time may be increased or decreased depending on the use of set retarding admixtures or the ambient weather conditions of temperature, wind, and humidity.

5. Multiple Lift Placement

a. The thickness of each lift will meet the requirements of Subsection 442.3.05.C.3, "Lift Thickness".

b. Place second lift within 60 minutes of the completion of the first lift. 
c. If more than 60 minutes has elapsed, the interface between the first and second lift will be considered a cold joint. Prepare cold joint in accordance with Subsection 442.3.05.E.4, "Horizontal Cold Lift Joints".

d. At the discretion of the Engineer, this time may be increased or decreased depending on the use of set retarding admixtures or the ambient weather conditions of temperature, wind, and humidity.

e. To reduce the opportunity for cold joints to develop, the use of multiple pavers in tandem formation is advantageous.

6. Hand Spreading

a. Limit hand spreading, broadcasting, or fanning to immediately behind the paver and before compaction.

b. Remove any segregated coarse aggregate from the surface before compaction.

7. Segregation

a. If segregation occurs in the RCC during paving operations, cease the spreading until the cause is determined and corrected to the satisfaction of the Engineer.

b. If the Engineer determines the segregation to be severe, remove and replace the segregated area at no additional cost.

Place RCC in a pattern so that the curing water from the previous placements will not pose a runoff problem on the fresh RCC surface or on the subbase layer.

D. Compacting

1. Immediately begin compaction behind the placement of RCC material and complete within 60 minutes of the start of mixing at the plant.

2. This time may be increased or decreased depending on the use of set retarding admixtures or ambient weather conditions of temperature, wind and humidity.

3. Plan operations and supply sufficient rollers to ensure these criteria are met.

4. Determine the sequence and number of passes by vibratory and non-vibratory rolling to obtain the specified density and surface finish.

5. Operation of rollers in the vibratory mode while stopped or reversing direction is not allowed.

6. Using rubber tire rollers for final compaction to knead and seal the surface is permissible.

7. Rolling Longitudinal and Transverse Joints:

a. Do not operate roller within $12 \mathrm{in.}(300 \mathrm{~mm})$ of the edge of a freshly placed lane until the adjacent lane is placed.

b. Within the allowable time roll together both edges of the two lanes.

\section{Section 442-Roller Compacted Concrete Pavement Page 7}

c. When a cold joint is planned, roll the complete lane and follow cold joint procedures as specified in Subsection

442.3.05.E.2, "Cold Vertical Joints".

d. Provide additional rolling for longitudinal joints with a vibratory roller as necessary to produce the specified density for the full depth of the lift and provide a tight smooth transition across the joint. 
e. Smooth out any uneven marks left during the vibratory rolling utilizing a non-vibratory or rubber tire roller.

f. Roll until a smooth, flat surface, free of tearing and cracking is obtained.

g. Avoid displacement of RCC pavement by operating the speed of the rollers slow enough at all times.

h. Correct any displacement of RCC pavement resulting from reverse direction of the roller or from any other causes.

8. Density Requirements:

a. Perform in-place field density tests in accordance with GDT-59, direct transmission, as soon as possible, but no later than 30 minutes after completion of rolling. Only wet density will be used for evaluation.

b. In-place field density will be not less than $98 \%$ of the average maximum laboratory density obtained according to AASHTO T 180, Method D, based on a moving average of five consecutive tests, with no test below $95 \%$.

c. RCC properly placed and compacted, but not meeting these requirements will be cored and tested at no additional cost.

d. If tested area achieves the 28 day design strength as outlined in Subsection 442.3.06.D, "Concrete Strength

Acceptance", it will be paid for at full price.

e. Areas that fail the strength test will be removed and replaced at no additional cost.

E. Joints

1. Fresh Vertical Joints:

a. A vertical joint is considered a fresh joint when an adjacent RCC lane is placed within 60 minutes of placing the previous lane, with time adjusted depending on use of retarders or ambient conditions. Fresh joints will not require the treatment specified for cold joints. b. Construct joints to assure continuous bond between new and previously placed lanes.

2. Cold Vertical Joints:

Note: Vertical joints that are constructed utilizing a drop extension or edging shoe are exempt from the following requirement when placed up to 15 degrees from vertical.

a. Cold joints are any planned or unplanned construction joint in the RCC pavement that does not qualify as fresh joints.

Treat longitudinal and transverse cold joints as followed:

1) Cut the joint vertically full depth. Cut vertically at least 6 in. $(150 \mathrm{~mm})$ from the exposed edge.

2) The edge of cold joints cut within 2 hours of placing the RCC pavement may be cut with an approved wheel cutter, or motor grader or other approved method provided that no edge raveling occurs.

3) Edges of cold joints cut after 2 hours of placing the RCC pavement, cut to $1 / 4$ to $1 / 3$ of the depth of the

RCC pavement and excess material removed.

4) If the excess material cannot be removed without causing tearing and raveling, cut full depth.

b. Clean the joint of any loose or foreign material prior to placing fresh RCC material against a compacted cold vertical joint. 
c. Before placement of fresh RCC, wet the compacted cold joint to prevent excess loss of moisture.

\section{Section 442-Roller Compacted Concrete Pavement Page 8}

\section{Fresh Horizontal Joints}

a. For multi-layer construction, a horizontal joint is considered a fresh joint when an subsequent RCC lift is placed within 60 minutes of placing the previous lift, with time adjusted depending on use of retarders or ambient weather conditions.

b. Clean the surface of all loose material and moisten the surface prior to placement of the subsequent lift.

4. Horizontal Cold Lift Joints

a. For horizontal cold joints, clean all loose material and moisten the surface prior to placement of the subsequent lift.

b. The Engineer or Plans may require use of a cement slurry or grout between lifts. If required, apply supplementary bonding materials immediately prior to placement of the subsequent lift.

5. Control Joints:

Joint locations shall be shown on the Plans or as directed by the Engineer.

a. Early entry saws should be utilized as soon as possible behind the rolling operation and set to the manufacturer's recommendation.

b. Saw cut control joints to 1/4 depth of the compacted RCC pavement.

c. Saw as soon as possible without causing raveling or other damage to the pavement, but no later than 18 hours after placement.

6. Joints at Structures

Treat joints between RCC pavement and concrete structures as cold vertical joints.

F. Finishing

1. The finished surface of the RCC pavement, when tested with a 10 foot $(3 \mathrm{~m})$ straight edge or crown surface template, will not vary by more than $1 / 4$ inch $(6 \mathrm{~mm})$ at any one point.

2. When the surface smoothness is outside of the specified tolerance, grind the surface to within the tolerance by use of self-propelled diamond grinders at no additional cost.

3. Milling to obtain a final riding surface is not acceptable.

G. Curing

Immediately after final rolling and compaction testing, keep the surface of the RCC

pavement continuously moist for 7 days or until an approved curing method is applied.

\section{Water Cure:}

a. Apply water cure using water truck equipped with misting spray nozzles, soaking hoses, sprinkler system or other means that will assure a uniform moist condition to the RCC.

b. Apply moisture in a manner that will not wash out or damage the surface of the finished RCC pavement.

2. Curing Compound:

a. Apply curing compound as specified in Subsection 430.3.05.L.1 of the Specifications. 
b. Ensure the application provides a uniform void-free membrane across the entire RCC pavement surface.

3. White Polyethylene Sheeting

Use sheet material as specified in Subsection 430.05.L.2 of the Specifications

H. Sealing Joints

If required by the Plans or directed by the Engineer, seal joints in accordance to

Subsection 430.3.05.M, "Seal the Joints" of the Specifications.

Section 442-Roller Compacted Concrete Pavement Page 9

I. Permitting Traffic on Pavement

Before using the pavement as a haul road for loaded or unloaded vehicles:

1. Protect the RCC from vehicular traffic during the curing period.

2. Ensure that compressive strength tests show the RCC has developed at least $2000 \mathrm{psi}$ $(14 \mathrm{MPa})$ and is at least 4 days old.

3. If required by the Plans or directed by the Engineer, seal the joints before permitting vehicles or equipment on the pavement.

442.3.06 Quality Acceptance

A. Concrete Mixing

Ensure mixing of RCC conforms to the requirements of Subsection 442.3.05.A, "Mixing RCC".

\section{B. Approval of Mix Design Proportions}

The Office of Materials and Research will review concrete mix designs and will verify compressive strength development.

The Department will approve material combinations and mix designs using approved materials and complying with

Subsection 442.2, "Materials" and the following:

1. Compressive Strength

Prepare and test 6 cylinders according to ASTM C 1435 and AASHTO T 22 to determine the 28 day compressive strength for RCC.

The mix design will demonstrate a compressive strength of $4000 \mathrm{psi}(28 \mathrm{MPa})$ at 28 days.

\section{Thickness}

The Engineer will designate pavement areas to be examined for depth measurement compliance with the Plan and Specifications.

The Engineer will evaluate areas deficient by more than $1 / 2$ in $(13 \mathrm{~mm})$ thick. If the Engineer requires removal, remove and replace the pavement in full cross sections according to Plan requirements. The Engineer may require a reduction in payment if removal and replacement is not required. 
D. Concrete Strength Acceptance

RCC pavement not meeting density requirements outlined in Subsection 442.3.05.D.8, "Density Requirements" will be accepted based on compressive strength development at 28 days. The compressive strength value shall be at least 3,500 psi (25 MPa).

442.3.07 Contractor Warranty and Maintenance

General Provisions 101 through 150.

442.4 Measurement

The work to be paid for under this Item is the number of square yards (meters) of RCC pavement completed and accepted as measured in place as determined by the specified lines, grades and cross sections shown on the Plans.

442.4 .01

General Provisions 101 through 150.

442.5 Payment

The work will be paid for at the Contract Unit Price per square yard (meter). Payment is full compensation for providing materials, equipment, and labor, mixing, transporting, handling, placing, compaction and providing incidentals to complete the work.

Payment will be made under:

Section 442-Roller Compacted Concrete Pavement Page 10

Item No. 442 Roller compacted concrete pavement Per square yard (meter) 442.5.01 Adjustments

The Contract Unit Price per square yard (meter) of RCC pavement will be adjusted for RCC pavement accepted with a 28 day compressive strength or thickness deficiency. 


\section{Review of Residential Pavement Design Options For Columbus, Ohio}

Prepared for

Nickolas Savko \& Sons, Inc.

Ohio Ready Mix Association

Ohio Concrete Association

Columbus, Ohio

Prepared by

Michael I. Darter, Ph.D, P.E.

Leslie Titus-Glover

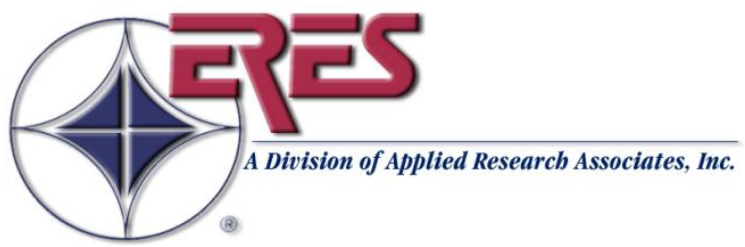

ERES Division of ARA, Inc.

505 West University Avenue

Champaign, IL 61820

17 August 2004 


\section{INTRODUCTION}

This report presents the results of a review of the Residential Pavement Design Options of the City of Columbus, Ohio. These standards are dated July 15, 2004. A copy of this table is provided as table 1 for reference. Each cell in the table 1a has been numbered as shown in table $1 \mathrm{~b}$ between 1 and 12 for referencing purposes. In addition to a review of the design options, some suggestions as to potential improvements are provided. This work was authorized by Nickolas Savko \& Sons, Inc., the Ohio Ready Mix Association, and the Ohio Concrete Association in August of 2004.

This review and suggested improvements was done in conjunction with the load carrying capacity analysis of a number of pavements located in the Columbus area (see Reference 3 ). These pavements were load tested with the FWD and a structural analysis of the data was accomplished. The pavements consisted of sections of roller compacted concrete (RCC) overlaid with hot mixed asphalt (HMA), sections of Portland cement concrete (PCC) slabs overlaid with HMA, and sections of conventional and full-depth HMA. Of particular value to this review are the inputs to the structural evaluation procedures that were found to be representative of these pavements in Columbus and surrounding communities.

The load carrying capacity analysis was conducted using two approaches: the AASHTO 1993 Design Guide (Reference 1) empirical approach and the NCHRP 1-37A (2004) Design Guide mechanistic-empirical (ME) based approach (Reference 2). The AASHTO 1993 procedure is used by the Ohio DOT and the City of Columbus for pavement design. The NCHRP 1-37A ME Design Guide is the result of 5 years of intensive development to move pavement design into a more fundamental and comprehensive engineering approach to design. The state highway agencies, FHWA, asphalt and concrete industries, and local highway agencies are currently reviewing this procedure to determine its suitability to serve as a new version of the AASHTO Design Guide. See the reference 1 in the appendix for a description of the ME Design Guide status.

\section{COLUMBUS DESIGN OPTIONS REVIEWED}

Table 1a summarizes the alternative design options under consideration by the City of Columbus. These design options are for three levels of traffic:

- ADT (two-way) 0 - 500: Conversion of ADT to ADTT was done by assuming 5 percent trucks (FHWA Class 4 to 13). This gives 25 ADTT (two-direction) in the initial year of the design.

- $\quad$ ADT (two-way) 501 - 1,500: Conversion of ADT to ADTT was done by assuming 5 percent trucks (FHWA Class 4 to 13). This gives 75 ADTT (two-direction) in the initial year of the design. 
Table 1a. Residential Pavement Design Options (DRAFT), City of Columbus, Ohio.
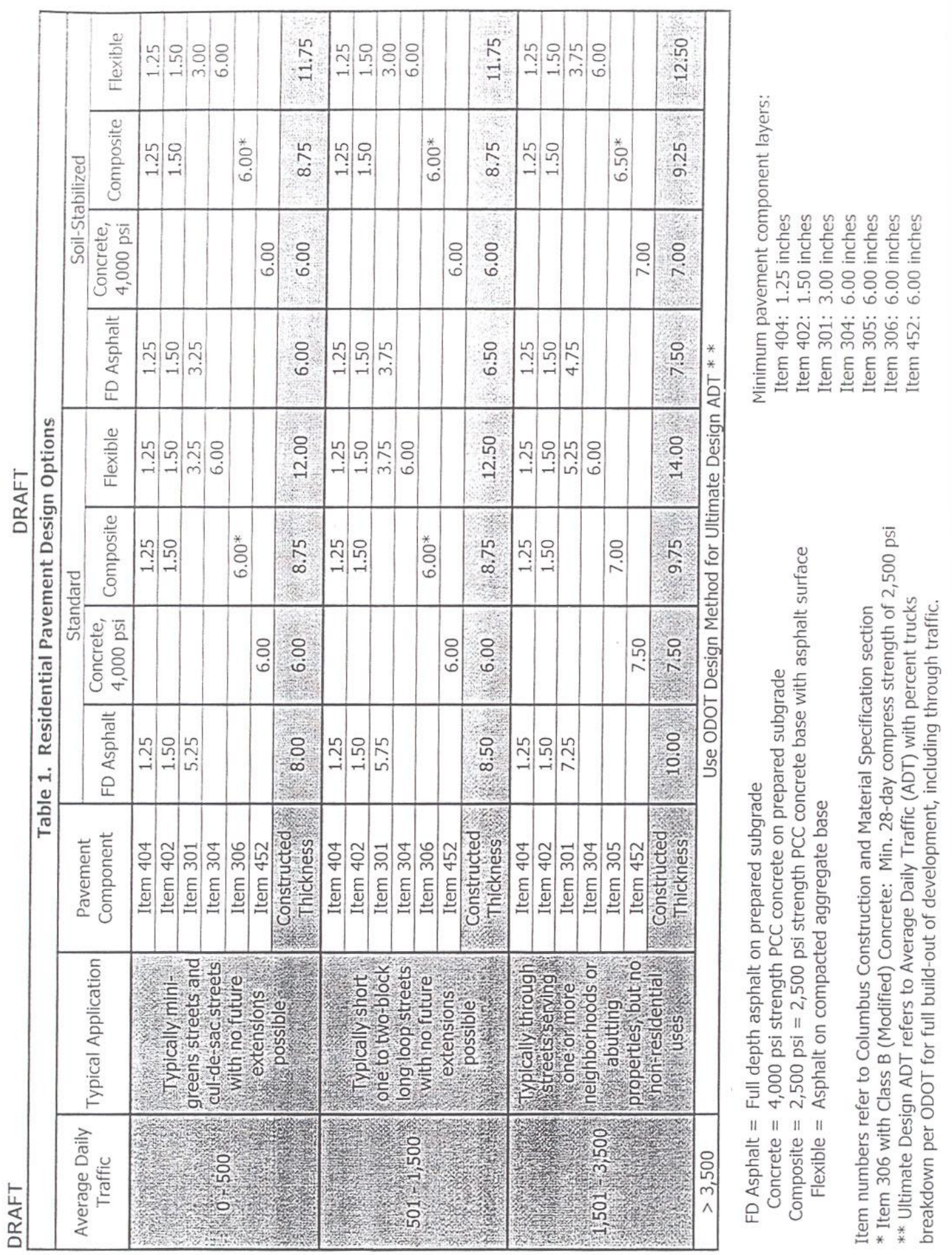
Table 1b. Table 1 Residential Pavement Design Options cell designation.

\begin{tabular}{|c|c|c|c|c|c|}
\hline $\begin{array}{c}\text { Average } \\
\text { Daily Traffic } \\
\text { ADT }\end{array}$ & $\begin{array}{c}\text { Average } \\
\text { Daily Truck } \\
\text { Traffic } \\
\text { ADTT* }\end{array}$ & $\begin{array}{c}\text { Full-Depth } \\
\text { Asphalt } \\
\text { Pavement }\end{array}$ & $\begin{array}{c}\text { Jointed Plain } \\
\text { Concrete } \\
\text { Pavement }\end{array}$ & $\begin{array}{c}\text { Composite } \\
\text { Pavement }\end{array}$ & $\begin{array}{c}\text { Flexible } \\
\text { Pavement }\end{array}$ \\
\hline $0-500$ & 25 & Cell 1 & Cell 4 & Cell 7 & Cell 10 \\
\hline $501-1,500$ & 75 & Cell 2 & Cell 5 & Cell 8 & Cell 11 \\
\hline $1,501-3,500$ & 175 & Cell 3 & Cell 6 & Cell 9 & Cell 12 \\
\hline
\end{tabular}

- $\quad$ ADT (two-way) 1501 - 3,500: Conversion of ADT to ADTT was done by assuming 5 percent trucks (FHWA Class 4 to 13). This gives 175 ADTT (two-direction) in the initial year of the design.

Table 1a also summarizes the pavement options being considered as follows:

- Full-depth Asphalt: hot-mixed asphalt (HMA) placed on prepared and compacted subgrade.

- Concrete: jointed plain concrete pavements without dowels.

- Composite: HMA placed over roller compacted concrete (RCC) or PCC base.

- Flexible: HMA placed over an unbound aggregate base course.

In addition, the stabilization of the top layer (e.g. 12-in) of the subgrade with lime or other chemical agent for each of the above designs is provided. This factor is not included in the analysis of this report. However, it can be analyzed and included at a later date if desired. The MR Design Guide software can directly consider a layer of stabilized material such as this at the top of the subgrade. 


\section{INPUTS FOR THE OPTIONAL DESIGNS}

The evaluation was conducted using the two procedures described above. The first step was to obtain proper inputs to use in these two procedures.

\section{AASHTO 1993 Inputs}

A detailed summary of the inputs used for the AASHTO 1993 Design Guide is summarized in Table 2. The traffic levels were set at the levels in Table 1 Design Options as described previously. This will provide a direct evaluation at a given level of design reliability of each cell in Table 1 Design Options.

The inputs are generally typical for these types of pavements and generally follow Ohio practice. The strength and modulus of the RCC and PCC are explained in some detail following Table 2. The resilient modulus of the subgrade soil was set at 4,800 psi for all pavement options which corresponds approximately to a CBR of 4 percent. This value is typical of the Columbus area.

Table 2. Summary of inputs used for the AASHTO 1993 Design Guide to evaluate pavement options.

\begin{tabular}{|l|l|l|l|}
\hline Design Input & Description & Flexible & Rigid/Composite \\
\hline Reliability & Design of all streets & 90 & 90 \\
\hline $\begin{array}{l}\text { Overall Standard } \\
\text { Deviation }\end{array}$ & $\begin{array}{l}\text { Considers variation of } \\
\text { materials, traffic, subgrade, } \\
\text { thickness, etc. }\end{array}$ & 0.49 & 0.39 \\
\hline Serviceability & Initial & 4.2 & 4.2 \\
\hline Serviceability & Terminal & 2.25 & 2.25 \\
\hline HMA Surfacing & Layer coefficient & 0.35 & --- \\
\hline HMA Intermediate & Layer coefficient & 0.35 & --- \\
\hline HMA Base & Layer coefficient & 0.30 & --- \\
\hline PCC Slab Material & $\begin{array}{l}\text { Mean Modulus of Rupture } \\
\text { Item 452 } \\
\text { Mean Modulus of Elasticity } \\
\text { Item 452 }\end{array}$ & --- & $\begin{array}{l}\text { MR }=700 \text { psi } \\
\text { E=4,000,000 psi } \\
\text { (from back- } \\
\text { calculation and cores } \\
\text { (Ref. 3) }\end{array}$ \\
\hline $\begin{array}{l}\text { RCC Base } \\
\text { Material }\end{array}$ & $\begin{array}{l}\text { Mean Modulus of Rupture } \\
\text { Item 306 } \\
\text { Mean Modulus of Elasticity } \\
\text { Item 306 }\end{array}$ & --- & $\begin{array}{l}\text { MR }=650 \text { psi } \\
\text { E=3,700,000 psi } \\
\text { (from back- } \\
\text { calculation) and } \\
\text { cores (Ref. 3) }\end{array}$ \\
\hline $\begin{array}{l}\text { Unbound } \\
\text { Aggregate Base }\end{array}$ & $\begin{array}{l}\text { Layer coefficient } \\
\text {--- }\end{array}$ \\
\hline
\end{tabular}


Table 2. Summary of inputs used for the AASHTO 1993 Design Guide to evaluate pavement options, continued.

\begin{tabular}{|c|c|c|c|}
\hline Design Input & Description & Flexible & Rigid/Composite \\
\hline $\begin{array}{l}\text { Drainage } \\
\text { coefficient }\end{array}$ & & 1.0 & 1.0 \\
\hline Subgrade & $\begin{array}{l}\text { Finegrained soil } \\
\mathrm{CBR}=4\end{array}$ & $\mathrm{Mr}=4,800 \mathrm{psi}$ & Same as flexible \\
\hline J Factor & Joint load transfer & --- & $\mathrm{J}=3.8$ \\
\hline \multirow[t]{3}{*}{ Traffic loadings } & $\begin{array}{l}5 \text { percent trucks } \\
50 \text { percent each direction } \\
\text { 2-lanes only } \\
3 \text { percent linear growth }\end{array}$ & $\begin{array}{l}\text { ADT }=500 \\
\text { ADTT }=25 \\
\text { trucks/day } \\
117,337 \text { trucks total } \\
\text { 20-years, design } \\
\text { lane }\end{array}$ & Same as flexible \\
\hline & & $\begin{array}{l}\text { ADT }=1,500 \\
\text { ADTT }=75 \\
\text { trucks/day } \\
352,010 \text { trucks total } \\
\text { 20-years, design } \\
\text { lane }\end{array}$ & Same as flexible \\
\hline & & $\begin{array}{l}\text { ADT }=3,500 \\
\text { ADTT }=25 \\
\text { trucks/day } \\
821,356 \text { trucks total } \\
\text { 20-years, design } \\
\text { lane }\end{array}$ & Same as flexible \\
\hline Loss of support & --- & & 1.0 \\
\hline
\end{tabular}

Notes to table 2.

*Mean values used for design of the Concrete and Composite pavements for the flexural strength and modulus of elasticity were determined as follows:

- Inputs required for the AASHTO 1993 and for the NCHRP 1-37A Design Guide are means of the flexural strength and modulus that would be achieved at construction. It is not correct to input minimum values required for quality control. This would add undue conservatism to the design. The mean strength provided is always well above the minimum required from construction specifications. The reliability procedure applied to the design considers variations in concrete strength, modulus, and many other factors and adjusts the design to meet the design reliability requirements. Inputting minimum strength and modulus values would be incorrect for both of these two design procedures.

- The mean static elastic modulus of RCC material was backcalculated from 8 projects in the field to be 4,452,000 psi.(Reference 3) The mean flexural strength as estimated from the elastic modulus was 698 psi. Cores taken from these pavements show 28-day compressive strengths averaging 5312 psi. This corresponds to a flexural strength of 
approximately $10(5312)^{\wedge} 0.5=729$ psi and a modulus of elasticity of $E=57,000$ $(5312)^{\wedge} 0.5=4,154,000 \mathrm{psi}$. These values agree well and provide a good basis for estimation of mean inputs for design that would be representative of these pavements. The mean values for 8 other projects with PCC base showed nearly identically the same mean strength and modulus values.

- Item 305 and Item 306 for composite pavement (2,500 psi minimum 28-day strength): Based on the above results, a mean flexural strength of 650 psi and modulus of elasticity of 3,705,000 psi was used in the design evaluation for concrete base in composite pavement.

- Item 452 for concrete pavement (4,000 psi minimum 28-day strength): Based upon the values above and the fact that a contractor always design the PCC mix to achieve much greater strength than the minimum required (typically 1,200 psi higher), it is believe that a compressive strength of $5,200 \mathrm{psi}$ is reasonable. This results in a mean flexural strength of $10(5200)^{\wedge} 0.5=721 \mathrm{psi}$. This results in a mean elastic modulus of $57,000(5200)^{\wedge} 0.5$ $=4,110,000$ psi. Values used in design are 700 psi and 4,000,000 psi at 28-days. 


\section{NCHRP 1-37A Design Guide Inputs}

Selected inputs used in the NCHRP 1-37A Design Guide are shown in table 3. There are many additional inputs that define the materials, traffic, climate, and soil conditions that are not included. These values were keyed to the local Columbus area. The traffic levels for the ME Design Guide were set at a "capacity" level for each cell in the Table 1 Design Options. It was felt that this approach would provide the best illustration of the ability of these pavement options to carry traffic.

Table 3. Summary of inputs for the ME Design Guide to evaluate pavement options.

\begin{tabular}{|c|c|c|c|}
\hline Design Input & Description & Flexible & Rigid/Composite \\
\hline Smoothness & Initial IRI & $63 \mathrm{in} / \mathrm{mi}$ & $63 \mathrm{in} / \mathrm{mi}$ \\
\hline HMA Surfacing & Mixture properties & Item 404 & Item 404 \\
\hline HMA Intermediate & Mixture properties & Item 402 & Item 402 \\
\hline HMA Base & Mixture properties & Item301 & --- \\
\hline $\begin{array}{l}\text { PCC Base } \\
\text { Material }\end{array}$ & $\begin{array}{l}\text { Mean Modulus of } \\
\text { Rupture Item } 452 \\
\text { Mean Modulus of } \\
\text { Elasticity Item } 452\end{array}$ & --- & $\begin{array}{l}\mathrm{MR}=700 \mathrm{psi} \\
\mathrm{E}=4,000,000 \mathrm{psi} \\
\text { (from back-calculation } \\
\text { and cores }\end{array}$ \\
\hline $\begin{array}{l}\text { RCC Base } \\
\text { Material }\end{array}$ & $\begin{array}{l}\text { Mean Modulus of } \\
\text { Rupture Item } 306 \\
\text { Mean Modulus of } \\
\text { Elasticity Item } 306\end{array}$ & --- & $\begin{array}{l}\mathrm{MR}=650 \mathrm{psi} \\
\mathrm{E}=3,700,000 \mathrm{psi} \\
\text { (from back-calculation) } \\
\text { and cores } *\end{array}$ \\
\hline $\begin{array}{l}\text { Unbound } \\
\text { Aggregate Base }\end{array}$ & Mixture properties & $\begin{array}{l}\text { Item } 304 \\
28,000 \text { psi (from } \\
\text { backcalculation) }\end{array}$ & --- \\
\hline Subgrade & $\begin{array}{l}\text { Finegrained soil } \\
\mathrm{CBR}=4\end{array}$ & $\mathrm{Mr}=4,800 \mathrm{psi}$ & Same as flexible \\
\hline \multirow[t]{3}{*}{ Traffic loadings } & $\begin{array}{l}5 \text { percent trucks } \\
50 \text { percent each } \\
\text { direction } \\
\text { 2-lanes only } \\
3 \text { percent linear } \\
\text { growth }\end{array}$ & $\begin{array}{l}\text { ADT }=500 \\
\text { ADTT }=25 \text { trucks/day } \\
117,337 \text { trucks total 20- } \\
\text { years, design lane }\end{array}$ & Same as flexible \\
\hline & & $\begin{array}{l}\text { ADT }=1,500 \\
\text { ADTT }=75 \text { trucks/day } \\
352,010 \text { trucks total 20- } \\
\text { years, design lane }\end{array}$ & Same as flexible \\
\hline & & $\begin{array}{l}\text { ADT }=3,500 \\
\text { ADTT }=25 \text { trucks/day } \\
821,356 \text { trucks total 20- } \\
\text { years, design lane }\end{array}$ & Same as flexible \\
\hline
\end{tabular}




\section{EVALUATION OF THE COLUMBUS DESIGN OPTIONS USING THE AASHTO 1993 PROCEDURE}

The AASHTO 1993 procedure was used to compute the ESALs that could be carried by each of the design options at the desired level of reliability (90 percent for all cells). This will allow for a direct evaluation of the pavement option in each of the 12 cells. The following question is addressed: Does this pavement section provide adequate structure to carry the design traffic for the 90 percent reliability level? If "yes" then the proposed Columbus design option is an acceptable design. If "no" then the proposed Columbus design is not an acceptable design.

Table 2 shows the inputs to evaluate the adequacy of each type of pavement to meet the serviceability requirements of the AASHTO Design Guide. The results are shown in table 5 for each type of pavement option.

- Full-depth asphalt meets or is close to the 90 percentile reliability requirements for the lowest level of traffic, 25 ADTT (500 ADT with 5\% trucks). Full-depth does not meet the 90 percent reliability requirements at the two higher levels of traffic.

- Concrete (JPCP) meets or is close to the 90 percent reliability requirements for all levels of traffic.

- Composite pavement far exceeds the 90 percent reliability for all levels of traffic.

- Flexible pavements meets the 90 percentile reliability requirements for the lowest level of traffic, 25 ADTT (500 ADT with 5\% trucks). Flexible pavement does not meet the 90 percent reliability requirements at the two higher levels of traffic.

Ratios of the design traffic (in ESALs) to the traffic carried at the 90 percent reliability level for each of these pavement types is shown in table 6. The mean ratios for each type of pavement option are given in table 7. The composite pavement option shows far more load carrying capacity than any other pavement option. The composite pavement ESALs at the 90 percent level of design reliability far exceeds the design traffic. The point could be made that the composite pavements are over designed and that a reduced design would be more appropriate for use in cost comparisons.

Table 4. Summary of ratio of design ESALs to the ESALs at the $90^{\text {th }}$ Percent Reliability for all pavement options.

\begin{tabular}{|c|c|c|}
\hline Pavement Option & $\begin{array}{c}\text { Range of Ratio: } \\
\text { Design ESALs/90 Percent } \\
\text { Reliability ESALs }\end{array}$ & $\begin{array}{c}\text { Mean Ratio: } \\
\text { Design ESALs/90 Percent } \\
\text { Reliability ESALs }\end{array}$ \\
\hline Full-Depth Asphalt pavement & 0.47 to 0.98 & 0.66 \\
\hline Concrete pavement & 0.93 to 2.81 & 1.68 \\
\hline Composite pavement & 3.90 to 12.45 & 6.83 \\
\hline Flexible pavement & 0.80 to 1.73 & 1.13 \\
\hline
\end{tabular}


Table 5. Results from the evaluation of Columbus pavement options using the AASHTO 1993 procedure.

\begin{tabular}{|c|c|c|c|c|c|c|c|}
\hline $\begin{array}{c}\text { Table } 1 \\
\text { Cell No. }\end{array}$ & $\begin{array}{c}\text { HMA } \\
\text { Thick- } \\
\text { ness } \\
\text { (in) }\end{array}$ & $\begin{array}{c}\text { RCC/PCC } \\
\text { \& Other } \\
\text { Thickness } \\
\text { (in) }\end{array}$ & $\begin{array}{c}\text { 20-year } \\
\text { Total No. of } \\
\text { Trucks } \\
\text { Design Lane } \\
\text { (1) }\end{array}$ & $\begin{array}{c}\text { Design } \\
\text { 20-year } \\
\text { Total No. of } \\
\text { ESALs } \\
\text { (2) }\end{array}$ & $\begin{array}{l}\text { 20-year } \\
90 \% \\
\text { Reliability } \\
\text { ESALs } \\
(3)\end{array}$ & $\begin{array}{c}\text { ESAL } \\
\text { Ratio } \\
\text { Rel/ } \\
\text { Design } \\
(3) /(2)\end{array}$ & $\begin{array}{c}\text { Design } \\
\text { Meets } \\
\text { Reli- } \\
\text { ability? }\end{array}$ \\
\hline $\begin{array}{c}1 \\
\text { Full-Depth } \\
\end{array}$ & 8 & NA & 117,337 & $58,669 *$ & 57,534 & 0.98 & Close \\
\hline $\begin{array}{c}2 \\
\text { Full-Depth }\end{array}$ & 8.5 & NA & 352,010 & $176,005^{*}$ & 82,329 & 0.47 & No \\
\hline $\begin{array}{c}3 \\
\text { Full-Depth }\end{array}$ & 10 & NA & 821,356 & $410,678^{*}$ & 218,451 & 0.53 & No \\
\hline $\begin{array}{c}4 \\
\text { Concrete }\end{array}$ & NA & 6 & 117,337 & $96,216 * *$ & 270,028 & 2.81 & Yes \\
\hline $\begin{array}{c}5 \\
\text { Concrete }\end{array}$ & NA & 6 & 352,010 & $288,648 * *$ & 270,028 & 0.93 & Close \\
\hline $\begin{array}{c}6 \\
\text { Concrete }\end{array}$ & NA & 7.5 & 821,356 & $673,512 * *$ & 883,716 & 1.31 & Yes \\
\hline $\begin{array}{c}7 \\
\text { Composite }\end{array}$ & 2.75 & 6 & 117,337 & $58,669 *$ & 730,261 & 12.45 & Yes \\
\hline $\begin{array}{c}8 \\
\text { Composite }\end{array}$ & 2.75 & 6 & 352,010 & $176,005^{*}$ & 730,613 & 4.15 & Yes \\
\hline $\begin{array}{c}9 \\
\text { Composite }\end{array}$ & 2.75 & 7 & 821,356 & $410,678 *$ & $1,600,545$ & 3.90 & Yes \\
\hline $\begin{array}{c}10 \\
\text { Flexible }\end{array}$ & 6 & 6 Agg. Base & 117,337 & $58,669 *$ & 101,450 & 1.73 & Yes \\
\hline $\begin{array}{c}11 \\
\text { Flexible }\end{array}$ & 6.5 & 6 Agg. Base & 352,010 & $176,005^{*}$ & 141,312 & 0.80 & No \\
\hline $\begin{array}{c}12 \\
\text { Flexible }\end{array}$ & 8 & 6 Agg. Base & 821,356 & $410,678 *$ & 350,926 & 0.85 & No \\
\hline
\end{tabular}

*Flexible pavement ESALs **Rigid pavement ESALs

(1) The total number of trucks traveling down the design lane during the 20-year period for each cell.

(2) ESALs for each cell computed by multiplying number of trucks by the mean truck factor ( 0.50 for flexible/composite and 0.82 for rigid).

(3) Computed number of ESALs using the AASHTO 1993 procedures for flexible/composite and rigid pavements using inputs from table2. 


\section{(4) EVALUATION OF THE DESIGN OPTIONS USING THE ME DESIGN GUIDE PROCEDURE}

The ME Design Guide is used to demonstrate the load carrying capacity of the design options provided in Table 1. This analysis is similar to that provided in the Reference 3 report on load carrying capacity. The inputs for each design option in Table 1 were coded into the ME Design Guide and it was then run over a 20 year period with a high level of traffic so that significant deterioration of the section was likely to occur and one of the limiting distress criteria would be reached. These are summarized in table 6 .

Table 6. "Failure" criteria defined for composite pavements and flexible pavements for Local or Collector streets.*

\begin{tabular}{|c|c|c|}
\hline Distress Type & $\begin{array}{c}\text { Composite } \\
\text { HMA/RCC or PCC } \\
\text { Base Pavement }\end{array}$ & $\begin{array}{c}\text { Flexible } \\
\text { Full-Depth HMA } \\
\text { Pavement }\end{array}$ \\
\hline $\begin{array}{c}\text { Transverse Fatigue Cracking } \\
\text { (of RCC/PCC) }\end{array}$ & $\begin{array}{c}70 \text { cracks / mile } \\
\text { (equivalent to approximately } \\
15 \% \text { slabs cracked) }\end{array}$ & N/A \\
$\begin{array}{c}\text { Transverse Slabs Cracked } \\
\text { (for bare jointed Concrete } \\
\text { pavement) }\end{array}$ & $15 \%$ slabs cracked & \\
\hline Rutting (permanent deformation) & 0.50 -in & 0.50 -in \\
\hline $\begin{array}{c}\text { Alligator (Fatigue) Cracking } \\
\text { (Bottom Up) }\end{array}$ & N/A & 15 percent lane area \\
\hline $\begin{array}{c}\text { Longitudinal Fatigue Cracking } \\
\text { (Top Down in Wheel Path) }\end{array}$ & $3000 \mathrm{ft} / \mathrm{mile}$ & $3000 \mathrm{ft} / \mathrm{mile}$ \\
\hline
\end{tabular}

*Note: these levels reflect the general guidelines found in the 1993 AASHTO Design Guide and in the ME Design Guide (NCHRP 1-37A) and the authors experience with pavement conditions where rehabilitation is often applied. These are not hard and fast rules and varies between highway agencies. Other limits could be used and this would affect the number of trucks carried until rehabilitation.

The results for the load carrying capacity are shown in table 7. The number of total trucks when each of the key distress types are exceeded are shown in the cells. For example, the full-depth asphalt design option Cell 1 shows the following results:

- Longitudinal fatigue top down cracking: 13.7 million trucks until 3,000 ft/mile is reached.

- Alligator fatigue bottom up cracking: 12.7 million trucks until 15 percent lane area is reached.

- Rut depth: 4.7 million trucks until 0.50-in mean rutting is reached.

In this case, the rutting would control the load carrying capacity of the pavement. 
Figure 1 shows a bar chart that illustrates these results for all 12 of the pavement options. Again, these are maximum load carrying capacity values in terms of numbers of heavy trucks. The means for each pavement option are provided in table 7 and in figure 1 and are summarized below.

- Full-depth Asphalt pavement cells: 4.7, 5,8, and 7.9 million trucks with an average of 6.1 million (approximately 3.1 million ESALs).

- Concrete (jointed plain) pavement cells: 0.9, 0.9, and 5.2 million trucks with an average of 2.3 million trucks (approximately 1.9 million ESALs)

- Composite pavement cells: all greater than 23.5 million trucks (approximately 11.8 million flexible ESALs and 19.3 rigid ESALs).

- Flexible pavement cells: 2.6, 3.0, and 4.7 million trucks with an average of 3.4 million (approximately 1.7 million ESALs).

Clearly, the composite pavement shows the highest load carrying capacity of all pavement options. This same result was found when analyzing actual in service pavements in the Columbus area (Reference 3).

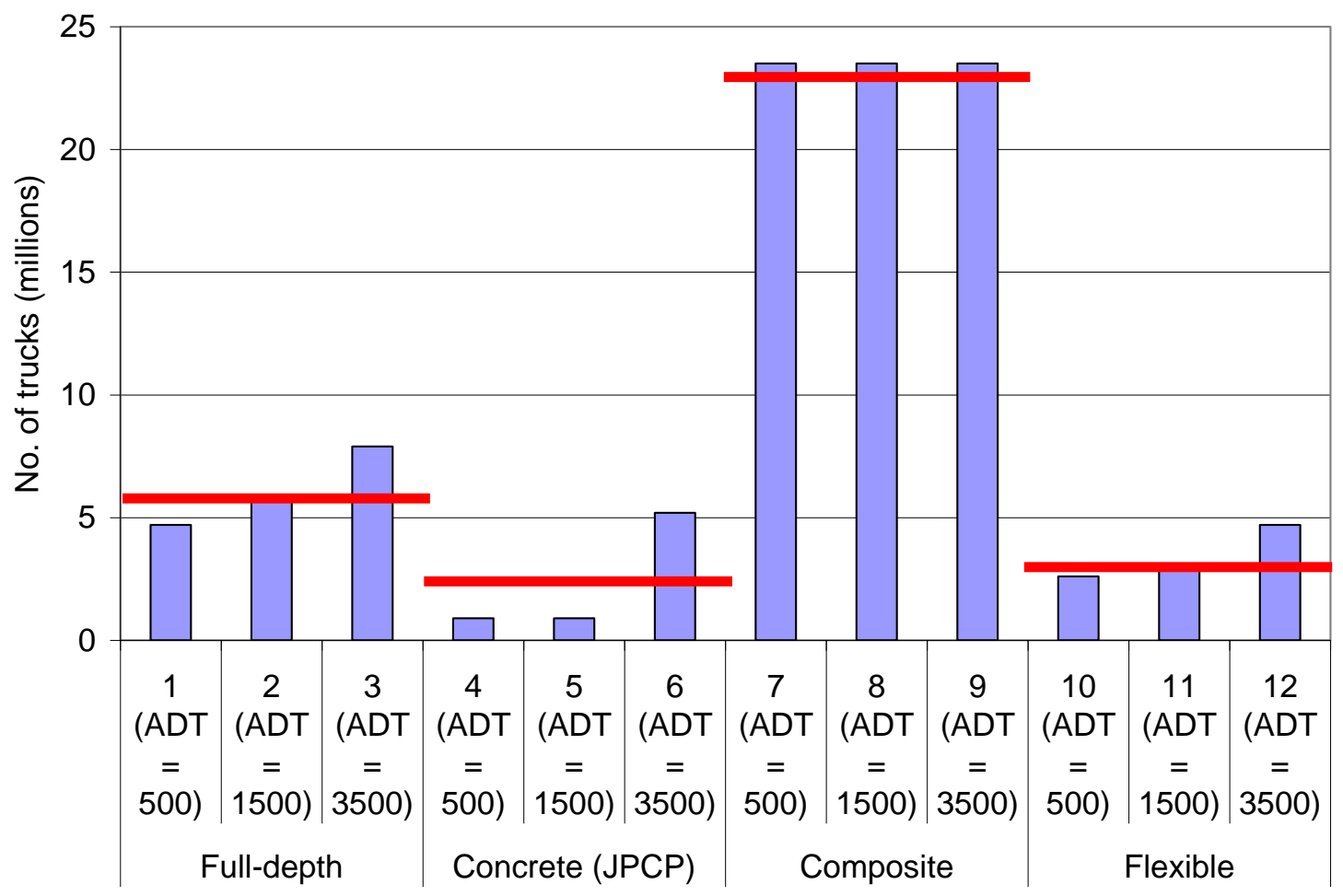

Figure 1. Load carrying capacity of pavement options. 
Table 7. Load carrying capacity of all pavement sections as determined by critical distress levels.

\begin{tabular}{|c|c|c|c|c|c|c|c|}
\hline \multirow[b]{2}{*}{$\begin{array}{c}\text { Pavement } \\
\text { Type }\end{array}$} & \multirow[b]{2}{*}{ Section ID } & \multicolumn{6}{|c|}{$\begin{array}{c}\text { No. of Trucks (Class } 4 \text { through 13) to Critical Distress Level } \\
\text { (millions of trucks) }\end{array}$} \\
\hline & & $\begin{array}{l}\text { Longitudinal } \\
\text { Cracking, } \\
\text { ft/mile }\end{array}$ & $\begin{array}{c}\text { Alligator } \\
\text { Cracking, } \\
\% \text { Area }\end{array}$ & $\begin{array}{c}\text { Rut } \\
\text { Depth, } \\
\text { in }\end{array}$ & $\begin{array}{l}\text { RCC/ PCC } \\
\text { Transverse } \\
\text { Cracking, } \\
\% \text { Slabs } \\
\text { Cracked }\end{array}$ & $\begin{array}{l}\text { Min. } \\
\text { Traffic }\end{array}$ & Mean \\
\hline \multirow{3}{*}{$\begin{array}{l}\text { Full-depth } \\
\text { Asphalt } \\
\text { Pavement }\end{array}$} & Cell 1 & $\begin{array}{c}13.7 \\
\text { million } \\
\text { trucks }\end{array}$ & $\begin{array}{l}12.7 \\
\text { million } \\
\text { trucks }\end{array}$ & $\begin{array}{c}4.7 \\
\text { million } \\
\text { trucks }\end{array}$ & $\begin{array}{l}\mathrm{N} / \mathrm{A} \\
\text { million } \\
\text { trucks }\end{array}$ & $\begin{array}{c}4.7 \\
\text { million } \\
\text { trucks }\end{array}$ & \multirow{3}{*}{$\begin{array}{c}6.1 \\
\text { million } \\
\text { trucks }\end{array}$} \\
\hline & Cell 2 & $>23.5$ & 18.1 & 5.8 & N/A & 5.8 & \\
\hline & Cell 3 & $>23.5$ & $>23.5$ & 7.9 & N/A & 7.9 & \\
\hline \multirow{3}{*}{$\begin{array}{l}\text { Concrete } \\
\text { Jointed Plain } \\
\text { Pavement }\end{array}$} & Cell 4 & N/A & N/A & N/A & 0.9 & 0.9 & \multirow{3}{*}{$\begin{array}{c}2.3 \\
\text { million } \\
\text { trucks }\end{array}$} \\
\hline & Cell 5 & N/A & N/A & N/A & 0.9 & 0.9 & \\
\hline & Cell 6 & N/A & N/A & N/A & 5.2 & 5.2 & \\
\hline \multirow{3}{*}{$\begin{array}{l}\text { Composite } \\
\text { Pavement }\end{array}$} & Cell 7 & $>23.5$ & N/A & $>23.5$ & $>23.5$ & $>23.5$ & \multirow{3}{*}{$\begin{array}{l}>23.5 \\
\text { million } \\
\text { trucks }\end{array}$} \\
\hline & Cell 8 & $>23.5$ & N/A & $>23.5$ & $>23.5$ & $>23.5$ & \\
\hline & Cell 9 & $>23.5$ & N/A & $>23.5$ & $>23.5$ & $>23.5$ & \\
\hline \multirow{3}{*}{$\begin{array}{c}\text { Flexible } \\
\text { Pavement }\end{array}$} & Cell 10 & 3.5 & 5.6 & 2.6 & N/A & 2.6 & \multirow{3}{*}{$\begin{array}{c}3.4 \\
\text { million } \\
\text { trucks }\end{array}$} \\
\hline & Cell 11 & 5.4 & 8.2 & 3.0 & N/A & 3.0 & \\
\hline & Cell 12 & $>23.5$ & 21.9 & 4.7 & N/A & 4.7 & \\
\hline
\end{tabular}

Terminal distress criteria:

- Longitudinal top down fatigue cracking $=3000 \mathrm{ft} / \mathrm{mile}$.

- Bottom up fatigue (alligator) cracking $=15 \%$ area.

- Rut depth $=0.5$ in.

- Fatigue bottom up transverse cracking for RCC/PCC per mile $=70$. 


\section{SUGGESTIONS ON IMPROVEMENT OF THE COMPOSITE PAVEMENT DESIGN OPTION}

The composite pavement exceeded the load carrying capacity of the other pavement options by a large amount. This indicates that the composite pavement is in reality designed to a far higher reliability than any of the other pavement options. This would have several benefits including the following:

- Longer average service life of all composite pavements. Note, the long service life was documented in Reference 4 after a review of the Columbus city records on pavement life.

- Lower future maintenance and rehabilitation costs.

- An ideal "perpetual" pavement design where the base concrete layer experiences very little fatigue damage and the only rehabilitation needed will be the removal and replacement of the HMA surfacing at intervals as durability distress occurs over time (e.g., weathering of surface, oxidized and hardened asphalt resulting in random cracking, and raveling).

However, the down side is that this high reliability design may result in a higher initial cost. If required, the initial design could be modified to reduce its high load carrying capacity by one of the following ways.

- Thickness of the HMA could be reduced to a practical minimum, such as 1.5-in. This thickness has been built in Columbus for many years and has performed very well (see Reference 4). Some of the composite pavements evaluated under the Load Carrying capacity analysis had only a 1.5-in HMA surface and showed excellent performance. (Reference 3)

- Thickness of the base PCC or RCC could be reduced. It is not recommended to go below 6-in, however, as it would lead to fatigue damage and the base would exhibit fatigue cracking over time.

- Reduction in strength of the base PCC or RCC. This option is not recommended either for the same reason as above and to avoid possible durability problems.

Regarding the use of a thinner HMA surfacing layer for composite pavements, it is our understanding that the City of Columbus has 30 to 40 years of experience with composite pavements which exhibit an excellent performance history and low maintenance.(Reference 4) We also understand that the original composite section consisted of 7-in of PCC base with 1.5-in 402 and 1.25-in of 404 and this design was reduced to 6-in PCC or RCC with 1.5-in of 404 placed in a single lift. Again it is understood that this new design was implemented in or around 2003. Furthermore, table 1 shows that the City of Columbus has recently proposed to revise the composite design to include an intermediate HMA course which consists of 1.5-in of 402 and the revised composite section would know consist of 6-in of RCC/PCC with 1.5-in of 402 intermediate course with 1.25-in of 404 surface course. We understand that this revision was prompted by the concern that the density of the 404 surface courses were not meeting current 404 ODOT specification (that was adopted by the City of Columbus in 2003). 
Based on our experience with surface courses, it is our opinion that there is no reason why density can not be achieved on the 1.5-in single lift provided that the contractor use proper construction materials and procedures (e.g., proper asphalt content, proper roller pattern and timing, proper mixture temperature and aggregate size). We believe that adding the intermediate course would be unjustified both from an engineering design approach and economical standpoint. It is common knowledge that many mills and overlays of 1 to 1.5 -in with HMA is standard practice.

Finally, we must not overlook the test data collected during a recent FWD evaluation by our company which shows that the composite pavement design consisting of 6-in of RCC/PCC with 1.5-in of 404 demonstrated excellent results.

\section{SUMMARY OF FINDINGS}

A review of the Residential Pavement Design Options of the City of Columbus, Ohio shown in table 1 is documented in this report. In addition to a review of the design options, some suggestions as to potential improvements are provided. This review and suggested improvements was done in conjunction with the load carrying capacity analysis of a number of pavements located in the Columbus area (see Reference 3). These pavements were load tested with the FWD and an structural analysis of the data was accomplished. The pavements consisted of sections of roller compacted concrete (RCC) overlaid with hot mixed asphalt (HMA), sections of Portland cement concrete (PCC) base overlaid with HMA, and sections of conventional and full-depth HMA. Of particular value to this review are the inputs to the structural evaluation procedures that were found to be representative of these pavements in Columbus and surrounding communities.

The load carrying capacity analysis was conducted using two approaches: the AASHTO 1993 Design Guide (Reference 1) empirical approach and the NCHRP 1-37A (2004) Design Guide mechanistic-empirical (ME) based approach (Reference 2). The following results and findings were obtained.

\section{Design Evaluation using AASHTO 1993}

The AASHTO 1993 procedure was used to compute the ESALs that could be carried by each of the pavement design options at the desired level of reliability ( 90 percent for all cells). The following question was addressed: Does this pavement section provide adequate structure to carry the design traffic for the 90 percent reliability level? If "yes" then the proposed Columbus design option is an acceptable design. If "no" then the proposed Columbus design is not an acceptable design. 
Table 8 results were obtained from this design adequacy evaluation using the AASHTO Design Guide. These results indicate that a number of the Columbus Design Options do not meet a 90 percent reliability level of design for the given three levels of traffic streets. In all cases, the highest of the traffic ranges was used in the evaluation. Those that do not meet the desired reliability level could be modified to meet the criteria through thickness or material modifications. The composite pavement appears to be over designed and by far exceed the 90 percent reliability of design. This design could be modified also to more closely meet the requirement.

Table 8. Summary of results obtained from AASHTO 1993 evaluation of adequacy of Columbus pavement designs at 90 percent reliability level.

\begin{tabular}{|l|l|c|l|c|}
\hline $\begin{array}{l}\text { Traffic Level } \\
\text { (ADT) }\end{array}$ & $\begin{array}{l}\text { Full-Depth } \\
\text { Asphalt } \\
\text { Pavement }\end{array}$ & $\begin{array}{l}\text { Concrete } \\
\text { Jointed Plain } \\
\text { Pavement }\end{array}$ & $\begin{array}{l}\text { Composite } \\
\text { Pavement }\end{array}$ & $\begin{array}{l}\text { Flexible } \\
\text { Pavement }\end{array}$ \\
\hline $\begin{array}{l}\text { 0 to 500 (two- } \\
\text { way) } \\
\text { 5 percent trucks }\end{array}$ & $\begin{array}{c}\text { Close to } \\
\text { Acceptable }\end{array}$ & Acceptable & Acceptable & Acceptable \\
\hline $\begin{array}{l}\text { 501 to 1,500 (two- } \\
\text { way) } \\
\text { 5 percent trucks }\end{array}$ & Unacceptable & $\begin{array}{c}\text { Close to } \\
\text { Acceptable }\end{array}$ & Acceptable & Unacceptable \\
\hline $\begin{array}{l}\text { 1,501 to 3,500 } \\
\text { (two-way) } \\
\text { 5 percent trucks }\end{array}$ & Unacceptable & Acceptable & Acceptable & Unacceptable \\
\hline
\end{tabular}

\section{Load Carrying Capacity using NCHRP 1-37A}

The ME Design Guide models were used to predict the load carrying capacity of each pavement option. Limiting criteria were selected for each key distress type, including longitudinal top down fatigue cracking, alligator bottom up fatigue cracking, and rutting.

The mean number of heavy trucks (FHWA class 4 to 13) until the limiting criteria were exceeded were determined for each distress type. Table 9 shows the results for each traffic level and pavement option. 
Table 9. Summary of results obtained from NCHRP 1-37A Design Guide evaluation of the loadcarrying capacity of Columbus pavement design options.

\begin{tabular}{|l|l|l|l|l|}
\hline \multicolumn{1}{|c|}{$\begin{array}{c}\text { Traffic Level } \\
\text { Two-way ADT) }\end{array}$} & $\begin{array}{c}\text { Full-Depth } \\
\text { Asphalt } \\
\text { Pavement }\end{array}$ & $\begin{array}{c}\text { Concrete } \\
\text { Jointed Plain } \\
\text { Pavement }\end{array}$ & $\begin{array}{l}\text { 位 } \\
\text { Composite } \\
\text { Pavement }\end{array}$ & \multicolumn{1}{c|}{$\begin{array}{c}\text { Flexible } \\
\text { Pavement }\end{array}$} \\
\hline $\begin{array}{l}\text { 0 to 500 } \\
\text { 5 percent trucks }\end{array}$ & $\begin{array}{l}4,700,000 \\
\text { trucks to } \\
\text { terminal } \\
\text { distress }\end{array}$ & $\begin{array}{l}900,000 \text { trucks to } \\
\text { terminal distress } \\
>23,500,000 \\
\text { trucks to } \\
\text { terminal } \\
\text { distress }\end{array}$ & $\begin{array}{l}2,600,000 \\
\text { trucks to } \\
\text { terminal } \\
\text { distress }\end{array}$ \\
\hline $\begin{array}{l}\text { 501 to 1,500 } \\
\text { 5 percent trucks }\end{array}$ & $5,800,000$ & 900,000 & $>23,500,000$ & $3,000,000$ \\
\hline $\begin{array}{l}\mathbf{1 , 5 0 1} \text { to 3,500 } \\
\text { 5 percent trucks }\end{array}$ & $7,900,000$ & $5,200,000$ & $>23,500,000$ & $4,700,000$ \\
\hline
\end{tabular}

\section{Potential Modifications to Composite Pavement Design}

Clearly, the composite pavement shows the highest load carrying capacity of all pavement options. It exceeds the AASHTO design for 90 percent reliability and the NCHRP 1-37A model predictions for load carrying capacity. This same result was found when analyzing actual in service pavements in the Columbus area (Reference 3).

There are some benefits to this finding:

- Longer average service life of composite pavements. Note, this predicted long service life was identified in Reference 4 after a review of the Columbus city records on pavement life.

- Lower future maintenance and rehabilitation costs.

- An ideal "perpetual" pavement design where the base concrete layer experiences very little fatigue damage and the only rehabilitation needed will be the removal and replacement of the thin HMA surfacing at intervals as durability distress occurs over time (e.g., weathering of surface, oxidized and hardened asphalt resulting in random cracking, and raveling).

However, the down side is that this high reliability design may result in a higher initial cost. If required, the initial design could be modified to reduce its high load carrying capacity by one of the following ways.

- Thickness of the HMA could be reduced to a practical minimum, such as 1.5 -in. This thickness has been built in Columbus for many years and has performed very well (see Reference 3). Some of the composite pavements evaluated under the Load Carrying capacity analysis had only a 1.5-in HMA surface and showed excellent performance. A discussion on achieving density for this 1.5-in HMA layer is provided in the report. 
- Thickness of the base PCC or RCC could be reduced. It is not recommended to go below 6-in, however, as it would lead to increased fatigue damage and the base may exhibit fatigue cracking over time.

- Reduction in strength of the base PCC or RCC. This option is not recommended either for the same reason as above.

\section{References}

1. AASHTO. Guide for Design of Pavement Structures. American Association of State and Highway Transportation Officials, 1993.

2. NCHRP. Mechanistic-Empirical Design Guide for New and Rehabilitated Pavement Structures. Final Technical Report, Available from: http://www.trb.org/mepdg/home.htm. National Cooperative Highway Research Program, Washington DC, 2004.

3. Analysis of Pavement Load Carrying Capacity of RCC \& Full Depth HMA Pavements in Columbus, Ohio and Surrounding Communities, by M. I. Darter, L. Titus-Glover, and Dulce Rufino, 2004.

4. City of Columbus Pavement Alternatives' Study to Evaluate Current Pavement Standards of the City, Task 4, Technical report prepared by Resource International, Inc. for City of Columbus, September, 2001. 


\section{I C H A E L I. D A R T E R, Ph. D., P.E. Principal Engineer, Applied Research Associates, Inc. Emeritus Professor of Civil and Environmental Engineering, University of Illinois at Urbana-Champaign}

\section{EDUCATION}

Ph.D., Civil Engineering, University of Texas at Austin

M.S., Civil Engineering, University of Utah

B.S., Civil Engineering, University of Utah

\section{REGISTRATION}

Professional Engineer (National, Illinois, Utah, Maryland, and Arizona)

\section{PROFESSIONAL SUMMARY}

Dr. Darter has been involved with the AASHTO Design Guide throughout his entire career. He began his employment with the Utah Department of Transportation as a pavement and materials engineer from 1966 to 1970 implementing the original 1961 AASHTO Interim Guide. Utah implemented the Interim Guide during this time period including extensive laboratory testing, field serviceability measurements, and traffic load analyses to calculate ESALs. From 1970 to 1973, he worked for the Center for Transportation Research, University of Texas, developing and implementing the pavement design reliability procedure into the Texas pavement design system, which was successfully used by the Texas Highway Department for over 20 years. During this time he worked for Dr. Frank McCullough on the revisions to the 1971 version of the AASHTO Design Guide.

He then served as a Professor of Civil Engineering at the University of Illinois from 1973 to 1996, conducting research and teaching in pavement engineering where he taught the AASHTO Design Guide to many classes. During this time, he also conducted many practical pavement engineering consulting projects dealing with design, rehabilitation, and management. In 1996 he joined ERES Consultants, Inc. full-time.

Dr. Darter has conducted many national and state research and consulting projects in pavement design, evaluation, performance, rehabilitation, and management. He served as part of the national consulting team that produced the 1986 AASHTO Design Guide as co-team leader on Part III Rehabilitation and Part IV Mechanistic Concepts. He then served as PI on the development of the 1993 AASHTO Overlay Design Procedures which were incorporated into this version of the Guide. His recent work includes serving as the rigid pavement team leader of the NCHRP 1-37A (AASHTO) mechanistic based design procedure and also directly assisting Mr. John Hallin, the PI, to complete all of the portions of the Design Guide including rehabilitation and reliability. 
Dr. Darter was a key member of the ARA, Inc. team that was selected as the Neutral Third Party for the Ohio Pavement Selection Process Analysis in 2003. This team reviewed the Ohio DOT pavement type selection process and design procedures.

\section{Appendix G - Welded Wire Reinforcement Transportation Specifications}

A search of Transportation agencies specifications using the National Highway Specification website (http://fhwapap04.fhwa.dot.gov/nhswp/index.jsp) reveals that a minimum of 24 transportation agencies have included welded wire reinforcement (WWR) in their specifications. Specifications cover a wide range of applications:

- Concrete reinforcement

- Concrete repair

- MSE walls

- MSE wall panel reinforcement

- Reinforcement for pneumatically placed concrete

- Sound wall reinforcement

- Barrier wall construction

- Pier repair

- Concrete riprap

- Gabions

- Slope pavement

- Slope protection

- Ditch lining

- Sediment control fence

- Inlets/manholes

Specifications from Pennsylvania, Washington, Texas and Kansas illustrate typical language used by agencies. 


\section{$\underline{\text { Pennsylvania }}$}

709.3 STEEL WELDED WIRE FABRIC-AASHTO M 55 (ASTM A 185). From a manufacturer listed in Bulletin 15 , rigidly welded at joints and points of intersection to form a fabric reinforcement, and as shown on the Standard Drawings.

(a) Epoxy Coating (Where Indicated). ASTM A 884/A 884M, Type 1, Class A.

(b) Galvanized Welded Wire Fabric. Section 709.1(e). Galvanized Welded Wire Fabric may be substituted for Epoxy Coated Welded Wire Fabric. Galvanize according to ASTM A123 coating Grade $35-35 \mu \mathrm{m}$ (1.4 mils) minimum. Chromate in accordance with ASTM A767, Section 4.3.

709.4 DEFORMED WELDED WIRE FABRIC-AASHTO M 221 (ASTM A 497). From a manufacturer listed in Bulletin 15 and as shown on the Standard Drawings.

(a) Epoxy Coating (Where Indicated). Section 709.3(a).

(b) Galvanized Welded Wire Fabric. Section 709.1(e). Galvanized Deformed Wire Fabric may be substituted for Epoxy Coated Deformed Wire Fabric. Galvanize according to ASTM A123 coating Grade $35-35$ $\mu \mathrm{m}$ (1.4 mils) minimum. Chromate in accordance with ASTM A767, Section 4.3.

$\underline{\text { Washington }}$

\section{6-13.3(6) Welded Wire Faced Structural Earth Wall Erection}

The Contractor shall erect the welded wire wall reinforcement in accordance with the wall manufacturer's field construction manual and as approved by the Engineer. Construction geotextile for wall facing shall be placed between the backfill material within the reinforced zone and the coarse granular material immediately behind the welded wire wall facing, as shown in the Plans and the structural earth wall Working Drawings as approved by the Engineer. Geosynthetic reinforcing, when used, shall be placed in accordance with Sections 2-12.3 and 6-13.3(5).

\section{$\underline{\text { Texas }}$}

Welded Wire Fabric. For fabric reinforcement, use wire that conforms to ASTM A 82 or A 496. Use wire fabric that conforms to ASTM A 185 or A 497. Observe the relations shown in Table 2 among size number, diameter in inches, and area when ordering wire by size numbers, unless otherwise specified. Precede the size number for deformed wire with " $\mathrm{D}$ " and for smooth wire with "W." Designate welded wire fabric as shown in the following example: $6 \times 12-\mathrm{W} 16 \times \mathrm{W} 8$ (indicating 6-in. longitudinal wire spacing and 12-in. transverse wire spacing with smooth No. 16 wire longitudinally and smooth No. 8 wire transversely). 
Table 5

Minimum Lap Requirements for Bar Sizes through No. 11

\begin{tabular}{|c|c|c|c|}
\hline $\begin{array}{c}\text { Bar Size } \\
\text { Number (in.) }\end{array}$ & $\begin{array}{c}\text { Bar Size } \\
\text { Number }(\mathrm{mm})\end{array}$ & $\begin{array}{c}\text { Uncoated Lap } \\
\text { Length }\end{array}$ & $\begin{array}{c}\text { Coated Lap } \\
\text { Length }\end{array}$ \\
\hline 3 & 10 & $1 \mathrm{ft} .4$ in. & 2 ft. 0 in. \\
\hline 4 & 13 & $1 \mathrm{ft} .9$ in. & $2 \mathrm{ft} .8 \mathrm{in}$. \\
\hline 5 & 16 & $2 \mathrm{ft} .2$ in. & 3 ft. 3 in. \\
\hline 6 & 19 & $2 \mathrm{ft} .7$ in. & $3 \mathrm{ft} .11 \mathrm{in}$. \\
\hline 7 & 22 & $3 \mathrm{ft} .5$ in. & 5 ft. 2 in. \\
\hline 8 & 25 & $4 \mathrm{ft} .6$ in. & $6 \mathrm{ft} .9$ in. \\
\hline 9 & 29 & 5 ft. 8 in. & $8 \mathrm{ft} .6$ in. \\
\hline 10 & 32 & 7 ft. 3 in. & $10 \mathrm{ft} .11 \mathrm{in}$. \\
\hline 11 & 36 & $8 \mathrm{ft} .11$ in. & $13 \mathrm{ft} .5$ in. \\
\hline
\end{tabular}

Note: Bar size numbers (in.) are based on the number of eighths of an inch included in the nominal diameter of the bar. Bar size numbers ( $\mathrm{mm}$ ) approximate the number of millimeters included in the nominal diameter of the bar.

- Do not lap No. 14 or No. 18 bars.

- Lap spiral steel at least 1 turn.

- Splice welded wire fabric using a lap length that includes the overlap of at least 2 cross wires plus 2 in. on each sheet or roll. Splices using bars that develop equivalent strength and are lapped in accordance with Table 5 are permitted.

$\underline{\text { Kansas }}$

\section{2 - EPOXY COATED STEEL FOR CONCRETE REINFORCEMENT SECTION 1602 EPOXY COATED STEEL FOR CONCRETE REINFORCEMENT}

1602.1 DESCRIPTION

This specification covers the requirements for epoxy coated steel for concrete reinforcement. The protective epoxy coating is applied to the reinforcing steel by the electrostatic spray or the electrostatic fluidized-bed method.

1602.2 REQUIREMENTS

a. General.

(1) Appendices to the standards cited below that are identified as nonmandatory information in those standards, are to be considered mandatory information for the purposes of this specification.

(2) Applicators must be certified under the Concrete Reinforcing Steel Institute (CRSI) Epoxy Coating Plant Certification program.

b. Epoxy Coated Steel Bars.

(1) Unless shown otherwise in the Contract Documents, use uncoated steel bars that comply with SECTION 1601 for straight bars or SECTION 1604 for helical reinforcement.

(2) Apply an epoxy coating that complies with ASTM A 775.

(3) Fabricators must comply with the provisions of ASTM D 3963, "Standard Specification for Fabrication and Jobsite Handling of Epoxy-Coated Reinforcing Steel Bars."

c. Epoxy Coated Steel Wire and Welded Wire Fabric.

(1) Unless shown otherwise on the Contract Documents, use material which complies with SECTION 1603 for welded wire fabric or SECTION 1604 for steel wire.

(2) Apply an epoxy coating that complies with ASTM A 884, Type 1 with Class A coating thickness. 


\section{d. Dowel Bars and Straight Tie Bars for Pavement.}

(1) Unless shown otherwise in the Contract Documents, use uncoated steel bars that comply with SECTION 1601.

(2) Apply an epoxy coating that complies with ASTM A 775 or ASTM A 934. Bent tie bars should be coated and handled as regular epoxy coated steel bars under subsection $1602.2 \mathrm{~b}$.

(3) Coating or patching material need not be applied to the cut end faces of the bars. For dowel bars to be mounted in baskets, coating will not be required within 2 inches of the end that will be fixed in the supporting basket by welding.

(4) Cut the bars by a method that minimizes heat input and surface damage and results in no appreciable deformation of the ends.

1602.3 TEST METHODS

As specified in the ASTM standards referenced above.

1602.4 PREQUALIFICATION

a. Applicators. Epoxy coating applicator plants supplying material to KDOT projects must be prequalified. Send a copy of the most recent CRSI certification grade sheets and inspection notes to the Bureau of Materials and Research for review. Satisfactory certification will serve to prequalify the plant until the next anniversary date. In order to maintain prequalified status, send copies of the CRSI certification grade sheets and inspection notes each year as soon as they are received from CRSI.

b. Organic Coatings. Organic coatings used for protection of reinforcing steel under this specification must be prequalified under ASTM A 775 or in the case of dowel bars or straight tie bars for pavement, ASTM A

1600-5 1602 - EPOXY COATED STEEL FOR CONCRETE REINFORCEMENT 
934 if applicable. Manufacturers desiring to supply material should submit a certified test report by an independent laboratory regularly inspected by the Cement and Concrete Reference Laboratory (CCRL) to the Bureau of Materials and Research.

c. Patching Material for Organic Coatings. Patching material for organic coatings used for protection of reinforcing steel under this specification must be prequalified under ASTM D 3963. Manufacturers desiring to supply material should submit a certified test report by an independent laboratory regularly inspected by the Cement and Concrete Reference Laboratory (CCRL) to the Bureau of Materials and Research.

d. Prequalified Lists. The Bureau of Materials and Research will maintain lists of prequalified applicators, organic materials and patching materials for use on KDOT projects.

1602.5 BASIS OF ACCEPTANCE

Receipt and approval by the Regional Materials Laboratory of the documents required for the uncoated reinforcing steel.

Receipt and approval by the Regional Materials Laboratory of a certification prepared by the Plant that applied the coating, stating that all bars have been coated in accordance with this specification. Provide this certification to the KDOT representative at the coating plant.

Satisfactory results of bend tests (if applicable), coating thickness and continuity tests conducted on the coated material by representatives of KDOT.

Visual inspection at destination for proper tagging of each bundle to enable identification of each heat or lot, for condition and for other properties.

1600-6 